\title{
Production of Gasoline and Diesel from Biomass via Fast Pyrolysis, Hydrotreating and Hydrocracking: A Design Case
}

$\begin{array}{ll}\text { SB Jones } & \text { JE Holladay } \\ \text { C Valkenburg } & \text { DJ Stevens } \\ \text { CW Walton } & \text { C Kinchin } \\ \text { DC Elliott } & \text { S Czernik }\end{array}$

February 2009

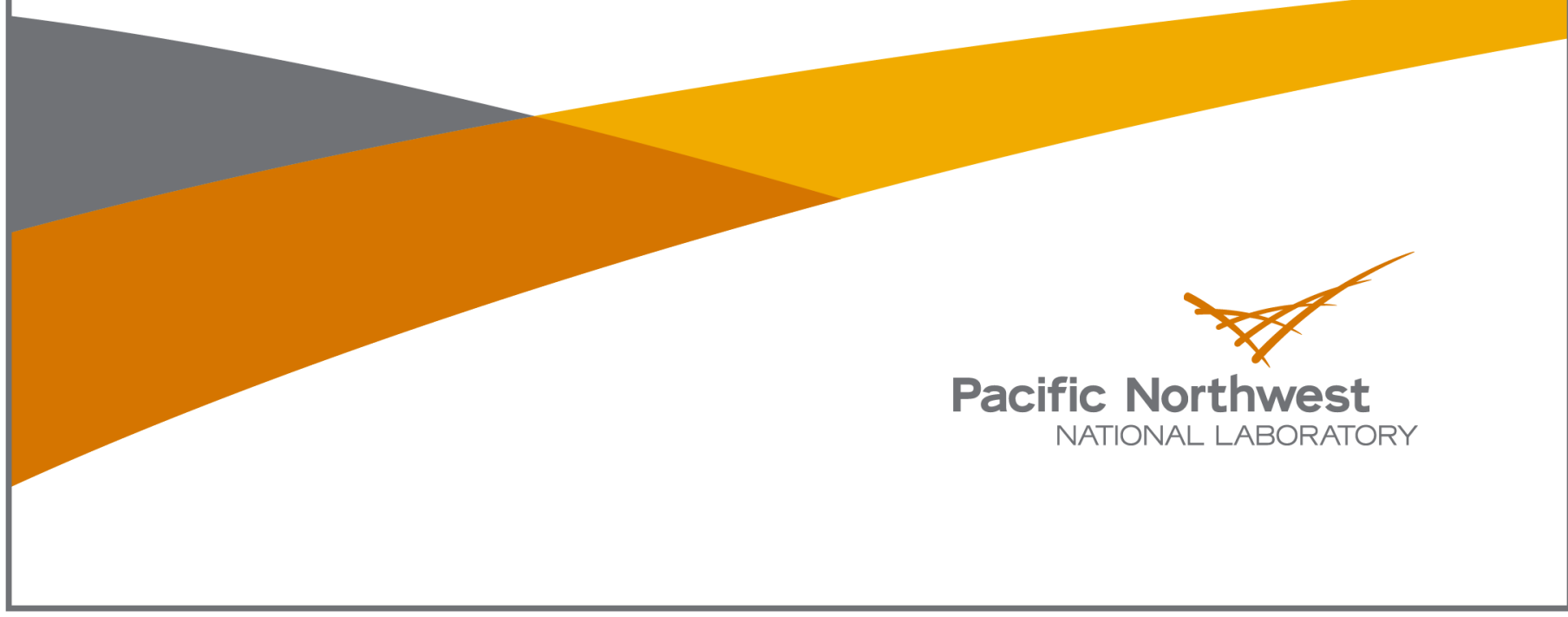




\title{
DISCLAIMER
}

This report was prepared as an account of work sponsored by an agency of the United States Government. Neither the United States Government nor any agency thereof, nor Battelle Memorial Institute, nor any of their employees, makes any warranty, express or implied, or assumes any legal liability or responsibility for the accuracy, completeness, or usefulness of any information, apparatus, product, or process disclosed, or represents that its use would not infringe privately owned rights. Reference herein to any specific commercial product, process, or service by trade name, trademark, manufacturer, or otherwise does not necessarily constitute or imply its endorsement, recommendation, or favoring by the United States Government or any agency thereof, or Battelle Memorial Institute. The views and opinions of authors expressed herein do not necessarily state or reflect those of the United States Government or any agency thereof.

\author{
PACIFIC NORTHWEST NATIONAL LABORATORY \\ operated by \\ BATTELLF \\ for the \\ UNITED STATES DEPARTMENT OF ENERGY \\ under Contract DE-AC05-76RL01830 \\ Printed in the United States of America \\ Available to DOE and DOE contractors from the \\ Office of Scientific and Technical Information, \\ P.O. Box 62, Oak Ridge, TN 37831-0062; \\ ph: (865) 576-8401 \\ fax: $(865) 576-5728$ \\ email: reports@adonis.osti.gov

\footnotetext{
Available to the public from the National Technical Information Service,

U.S. Department of Commerce, 5285 Port Royal Rd., Springfield, VA 22161

ph: (800) 553-6847

fax: $(703) 605-6900$

email: orders@ntis.fedworld.gov

online ordering: http://www.ntis.gov/ordering.htm
}

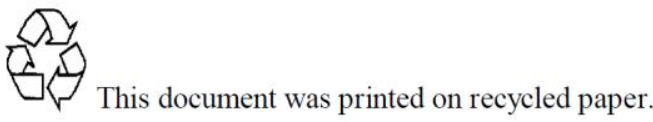

(9/2003) 


\title{
Production of Gasoline and Diesel from Biomass via Fast Pyrolysis, Hydrotreating and Hydrocracking: A Design Case
}

\author{
SB Jones ${ }^{1}$ \\ JE Holladay ${ }^{1}$ \\ C Valkenburg ${ }^{1}$ \\ DJ Stevens ${ }^{1}$ \\ CW Walton \\ DC Elliott ${ }^{1}$ \\ C Kinchin ${ }^{2}$ \\ S Czernik $^{2}$
}

February 2009

Prepared for

the U.S. Department of Energy

under Contract DE-AC05-76RL01830

Pacific Northwest National Laboratory

Richland, Washington 99352

\footnotetext{
${ }^{1}$ Pacific Northwest National Laboratory

${ }^{2}$ National Renewable Energy Laboratory
} 



\section{Executive Summary}

The President has established a goal to supply 35 billion gallons per year of renewable and alternative fuels by 2017. This goal is addressed in part by the U.S. Department of Energy (DOE) Office of Biomass Program's (OBP's) Thermochemical Platform multiyear program plan to "convert biomass to fuels, chemicals and power via thermal and chemical processes such as gasification, pyrolysis and other nonbiochemical processes" (DOE 2008).

In recent years, the Biomass Program completed technoeconomic evaluations of both biological and thermochemical pathways for converting biomass to ethanol. These "design case" studies provided a detailed basis for understanding the current state of various conversion technologies for producing fuel ethanol. The studies also helped identify technical barriers for which research and development could potentially lead to significant cost improvements. Consistent assumptions for items such as plant lifetimes, rates of return, and other factors were used in all cases so the various processes could be compared.

At present, the use of biomass resources to produce infrastructure-compatible fuels is appealing. Hydrocarbon biofuels can potentially be used without significant changes to the current fuel distribution and utilization infrastructure, including pipelines, pumping stations, and vehicles. Given the relatively short time between now and 2017, the goal of 35 billion gallons per year of renewable fuels will be more readily met if hydrocarbon biofuels are part of the fuel mix.

The purpose of this design case study is to evaluate a processing pathway for converting biomass into infrastructure-compatible hydrocarbon biofuels. This design case investigates production of fast pyrolysis oil from biomass and the upgrading of that bio-oil as a means for generating infrastructure-ready renewable gasoline and diesel fuels. Other options for pyrolytic processes and upgrading steps exist, but they were not evaluated in this study. Likewise, gasification pathways that could be used to produce hydrocarbons are not addressed here. This study has been conducted using the same methodology and underlying basis assumptions as the previous design cases for ethanol.

The overall concept and specific processing steps were selected because significant data on this approach exists in the public literature. The analysis evaluates technology that has been demonstrated at the laboratory scale or is in early stages of commercialization. The fast pyrolysis of biomass is already at an early stage of commercialization, while upgrading bio-oil to transportation fuels has only been demonstrated in the laboratory and at small engineering development scale. Advanced methods of pyrolysis, which are under development, are not evaluated in this study. These, may be the subject of subsequent analysis by OBP.

The plant is designed to use 2000 dry metric tons/day of hybrid poplar wood chips to produce 76 million gallons/year of gasoline and diesel. The processing steps include:

1. Feed drying and size reduction

2. Fast pyrolysis to a highly oxygenated liquid product

3. Hydrotreating of the fast pyrolysis oil to a stable hydrocarbon oil with less than $2 \%$ oxygen

4. Hydrocracking of the heavy portion of the stable hydrocarbon oil 
5. Distillation of the hydrotreated and hydrocracked oil into gasoline and diesel fuel blendstocks

6. Hydrogen production to support the hydrotreater reactors.

Note that the Idaho National Laboratory (INL) is working on feedstock logistics that will eliminate the need for drying and size reduction at the plant. That is, the "as received" feedstock to the pyrolysis plant will be "reactor ready". This development will likely further decrease the cost of producing the fuel.

The capital cost for a standalone " $\mathrm{n}$ "th" plant is $\$ 303$ million (2007 basis). At a $10 \%$ return on investment (ROI), the minimum fuels (gasoline + diesel) selling price is $\$ 2.04 /$ gal $(\$ 1.34 /$ gal ethanol equivalent basis).

An important sensitivity is the possibility of co-locating the plant with an existing refinery. In this case, the plant consists only of the first three steps: feed prep, fast pyrolysis, and upgrading. Stabilized, upgraded pyrolysis oil is transferred to the refinery for separation and finishing into motor fuels. The offgas from the hydrotreaters is also transferred to the refinery, and in return the refinery provides lower-cost hydrogen for the hydrotreaters. This reduces the capital investment to $\$ 188$ million and the minimum fuel selling price to $\$ 1.74 /$ gal ( $\$ 1.14 /$ gal ethanol equivalent basis).

Production costs near \$2/gal (in 2007 dollars) and petroleum industry infrastructure-ready products make the production and upgrading of pyrolysis oil to hydrocarbon fuels an economically attractive source of renewable fuels. The study also identifies technical areas where additional research can potentially lead to further cost improvements. 


\section{Acronyms and Abbreviations}

$\begin{array}{ll}\text { AR } & \text { As received } \\ \text { Btu } & \text { British thermal units } \\ \text { CFB } & \text { circulating fluid beds } \\ \text { DOE } & \text { U.S. Department of Energy } \\ \text { gal } & \text { gallon } \\ \text { HDS } & \text { hydrodesulfurized } \\ \text { HTS } & \text { high temperature shift } \\ \text { LHV } & \text { lower heating value } \\ \text { MFSP } & \text { minimum fuel product selling price } \\ \text { MM } & \text { Million } \\ \text { mm } & \text { millimeter(s) } \\ \text { mtpd } & \text { metric tons per day } \\ \text { MWth } & \text { megawatts thermal } \\ \text { OBP } & \text { Office of the Biomass Program } \\ \text { PSA } & \text { pressure swing adsorption } \\ \text { ROI } & \text { return on investment } \\ \text { tpd } & \text { tons per day } \\ \text { TPEC } & \text { total purchased equipment cost }\end{array}$





\section{Contents}

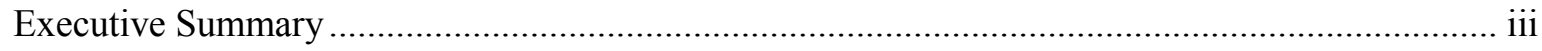

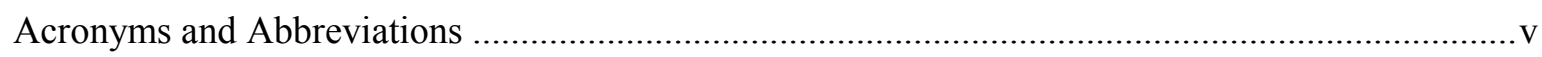

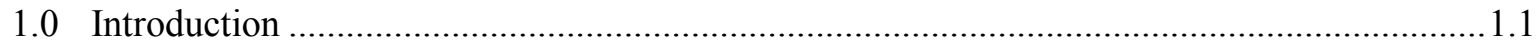

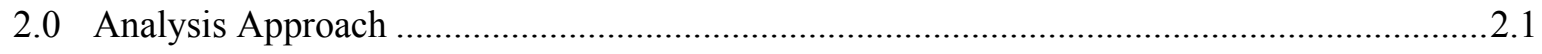

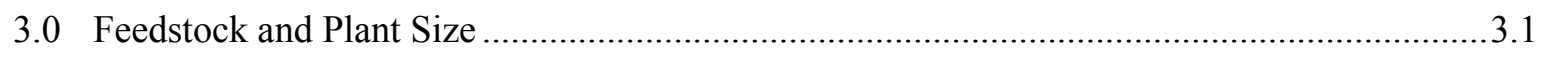

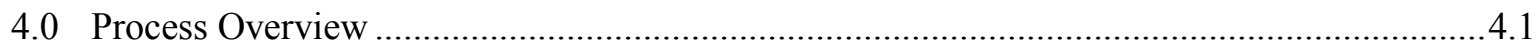

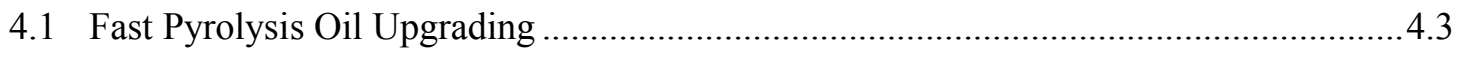

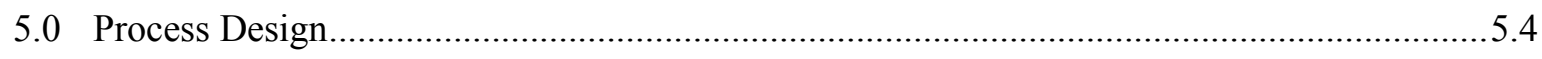

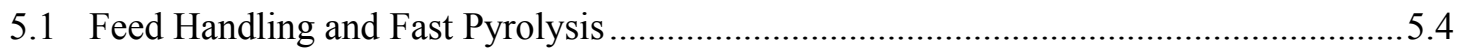

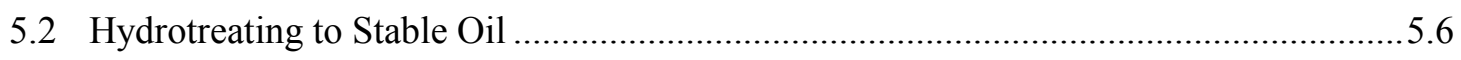

5.3 Hydrocracking and Product Separation.....................................................................

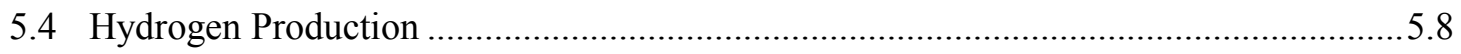

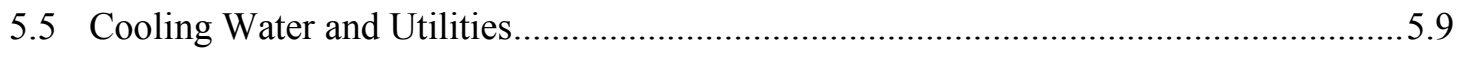

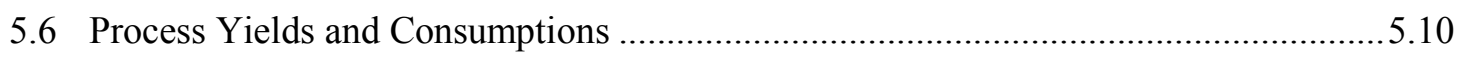

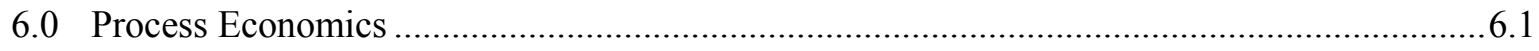

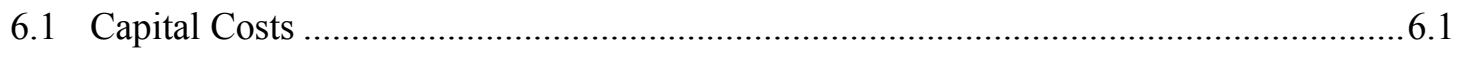

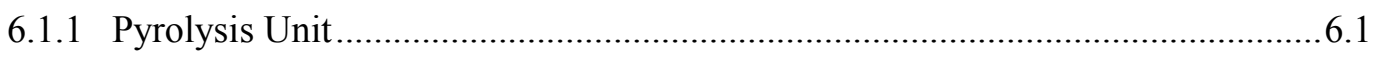

6.1.2 Pyrolysis Oil Hydrotreating and Hydrocracking .............................................. 6.1

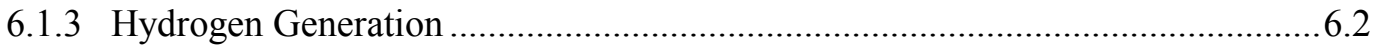

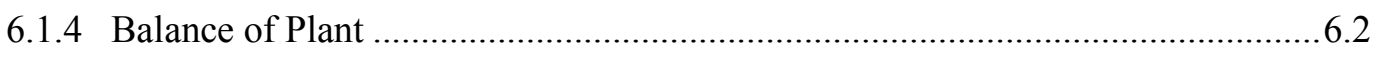

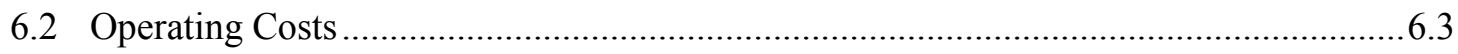

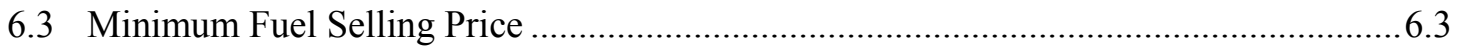

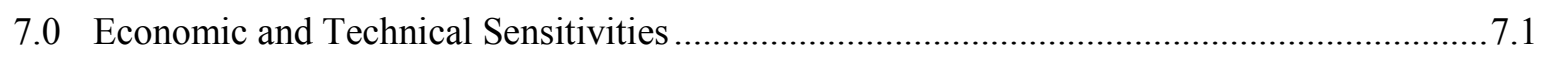

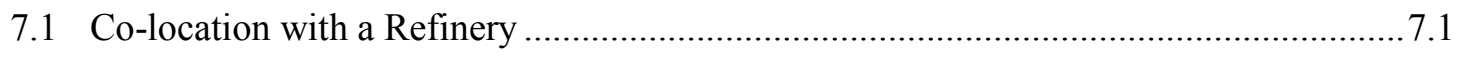

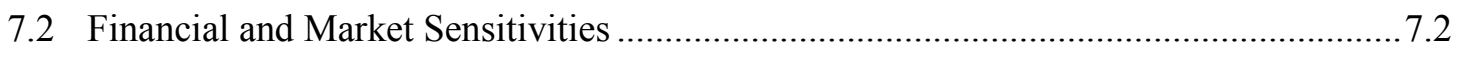

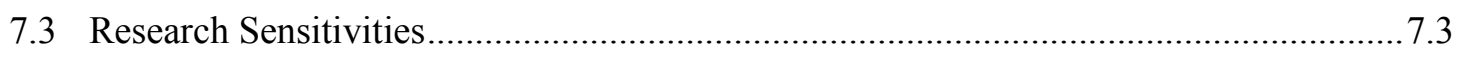

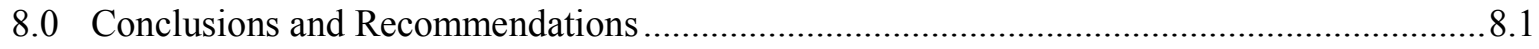

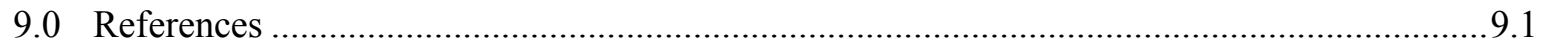

Appendix A Design Case - Stand-Alone Heat and Material Balance ..........................................4.4

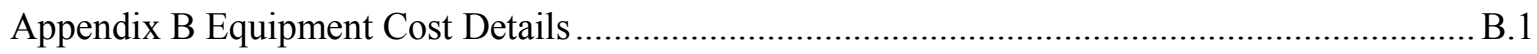




\section{Figures}

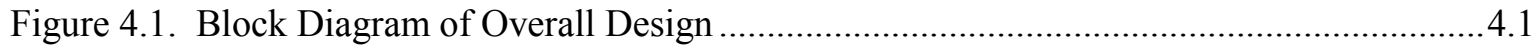

Figure 4.2. Typical Product Yields from Different Modes of Wood Pyrolysis .............................4.2

Figure 5.1. Block Diagram of Fast Pyrolysis .............................................................................. 5.4

Figure 5.2. Block Diagram of Bio-Oil Upgrading .............................................................. 5.6

Figure 5.3. Block Diagram of Hydrocracking and Product Separation ........................................5.8

Figure 5.4. Block Diagram of Hydrogen Production ..............................................................5.9

Figure 7.1. Block Diagram of Pyrolysis and Upgrading Plant Co-located with a Refinery ...........7.1

Figure 7.2. Financial/Market Sensitivities ................................................................................ 7.3

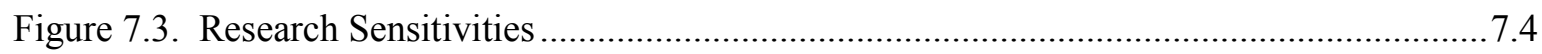

\section{Tables}

Table 5.1. Feedstock and Processing Assumptions ..................................................................5.5

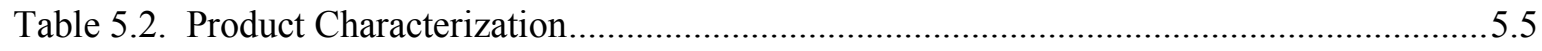

Table 5.3. Hydrotreating Conditions.................................................................................... 5.7

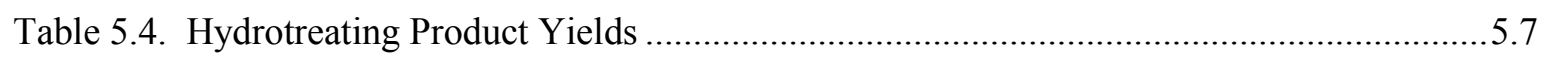

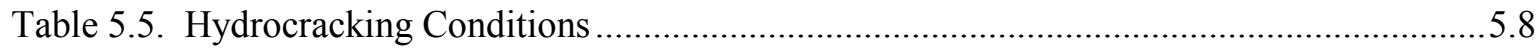

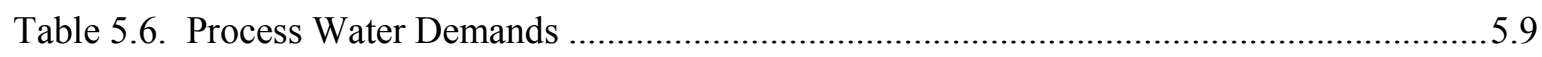

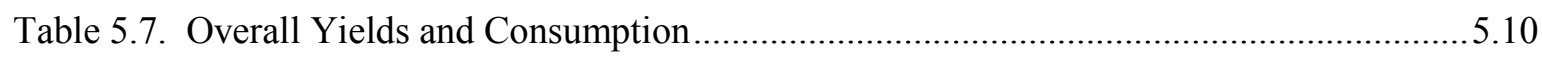

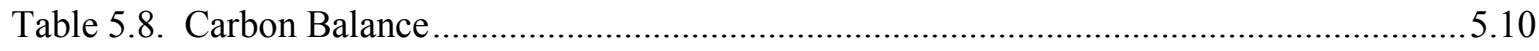

Table 6.1. Pyrolysis Unit Literature Capital Cost ......................................................................... 6.1

Table 6.2. Total Project Investment Cost for the Design Case Stand-Alone Plant........................6.2

Table 6.3. Total Project Investment Factors ............................................................................ 6.2

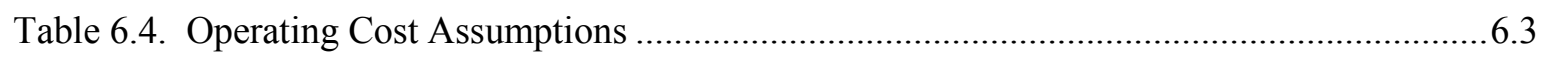

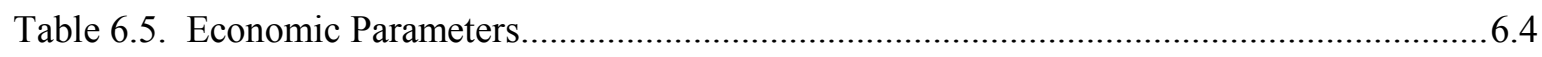

Table 6.6. Project Economics for the Stand-Alone Design Case Plant..........................................6.5

Table 7.1. Comparison of Integrated and Standalone Facilities .............................................. 7.2 


\subsection{Introduction}

The President has established a goal to supply 35 billion gallons per year of renewable and alternative fuels by 2017 (White House 2007). This goal is addressed in part by the U.S. Department of Energy (DOE) Office of the Biomass Program's (OBP's) Thermochemical Platform multiyear program plan to "convert biomass to fuels, chemicals and power via thermal and chemical processes such as gasification, pyrolysis, and other non-biochemical processes" (DOE 2008).

In recent years, the Biomass Program completed technoeconomic evaluations of both biological and thermochemical pathways for converting biomass to ethanol. These "design case" studies provided a detailed basis for understanding the current state of various conversion technologies for producing fuel ethanol. The studies also helped identify technical barriers where research and development could potentially lead to significant cost improvements. Consistent assumptions for items such as plant lifetimes, rates of return, and other factors were used in all cases so the various processes could be compared.

At present, the use of biomass resources to produce infrastructure-compatible fuels is appealing. Hydrocarbon biofuels can potentially be used without significant changes to the current fuel distribution and utilization infrastructure, including pipelines, pumping stations, and vehicles. Given the relatively short time before 2017, the goal of 35 billion gallons of renewable fuels will be more readily met if hydrocarbon biofuels are part of the fuel mix.

The purpose of this design case study is to evaluate a processing pathway for converting biomass into infrastructure-compatible hydrocarbon biofuels.

This design case investigates fast pyrolysis oil production from biomass and the upgrading of that bio-oil as a means for generating infrastructure-ready renewable gasoline and diesel fuels. The overall concept and specific processing steps were selected because significant data on this approach exist in the public literature. Other options for pyrolytic processes and upgrading steps exist, but they were not evaluated in this study. One example of alternative processing options is hydrothermal pyrolysis followed by other upgrading steps. Likewise, gasification pathways can be used to produce hydrocarbons, but those are also not addressed here. These and other options may be addressed in future studies.

The design case presented here represents a goal case targeting performance potentially available between now and 2015. This analysis evaluates technology that has been demonstrated at the laboratory scale or is in early stages of commercialization. The fast pyrolysis of biomass is already at an early stage of commercialization, while the upgrading of the bio-oil to transportation fuels has only been demonstrated in the laboratory and at small engineering development scale. As such, the analysis does not reflect the current state of commercially-available technology but includes advancements that are potentially achievable by 2015 .

The study has been conducted using the same methodology and underlying basis assumptions as the previous design cases for ethanol. It allows a basis for comparison with other research and development projects targeting the DOE objectives and lastly, provides a benchmark for the status of the pyrolysis program. 



\subsection{Analysis Approach}

The approach used is similar to that employed in previous conceptual process designs and associated design reports (Aden et al. 2002, Spath et al. 2005, Phillips et al. 2007). Process flow diagrams are based on literature information and research results; these data were then used to build a process model in CHEMCAD $^{\circ}$, a commercial process flow sheeting software tool. The capital costs were taken from literature sources or were obtained from Aspen ICARUS ${ }^{\mathrm{TM}}$ software after being sized using the $\mathrm{CHEMCAD}^{\odot}$ heat and material balances. The capital and operating costs were assembled in a Microsoft Excel $^{\odot}$ spreadsheet. A discounted cash flow method was used to determine the minimum product selling price. 



\subsection{Feedstock and Plant Size}

The feedstock is hybrid poplar wood chips delivered at $50 \mathrm{wt} \%$ moisture. The feedstock cost is assumed to be $\$ 50.7 /$ bone dry metric ton, delivered. This report takes a conservative approach and assumes the same moisture level as was used in previous studies (Aden et al. 2002, Spath et al. 2005, Phillips et al. 2007) and that feedstock grinding and drying occur at the plant.

The plant capacity is 2000 metric tons/day (mtpd) of bone dry wood. The plant is assumed to be an established (" $n$ th") plant design, rather than a first of its kind. 



\subsection{Process Overview}

A simplified block diagram of the overall design is given in Figure 4.1. The processing steps include:

1. Feed drying and size reduction

2. Fast pyrolysis to a highly oxygenated liquid product

3. Hydrotreating of the fast pyrolysis oil to a stable hydrocarbon oil with less than $2 \%$ oxygen

4. Hydrocracking of the heavy portion of the stable hydrocarbon oil

5. Distillation of the hydrotreated and hydrocracked oil into gasoline and diesel fuel blendstocks

6. Steam reforming of the process off-gas and supplemental natural gas to produce hydrogen for the hydrotreating and hydrocracking steps.

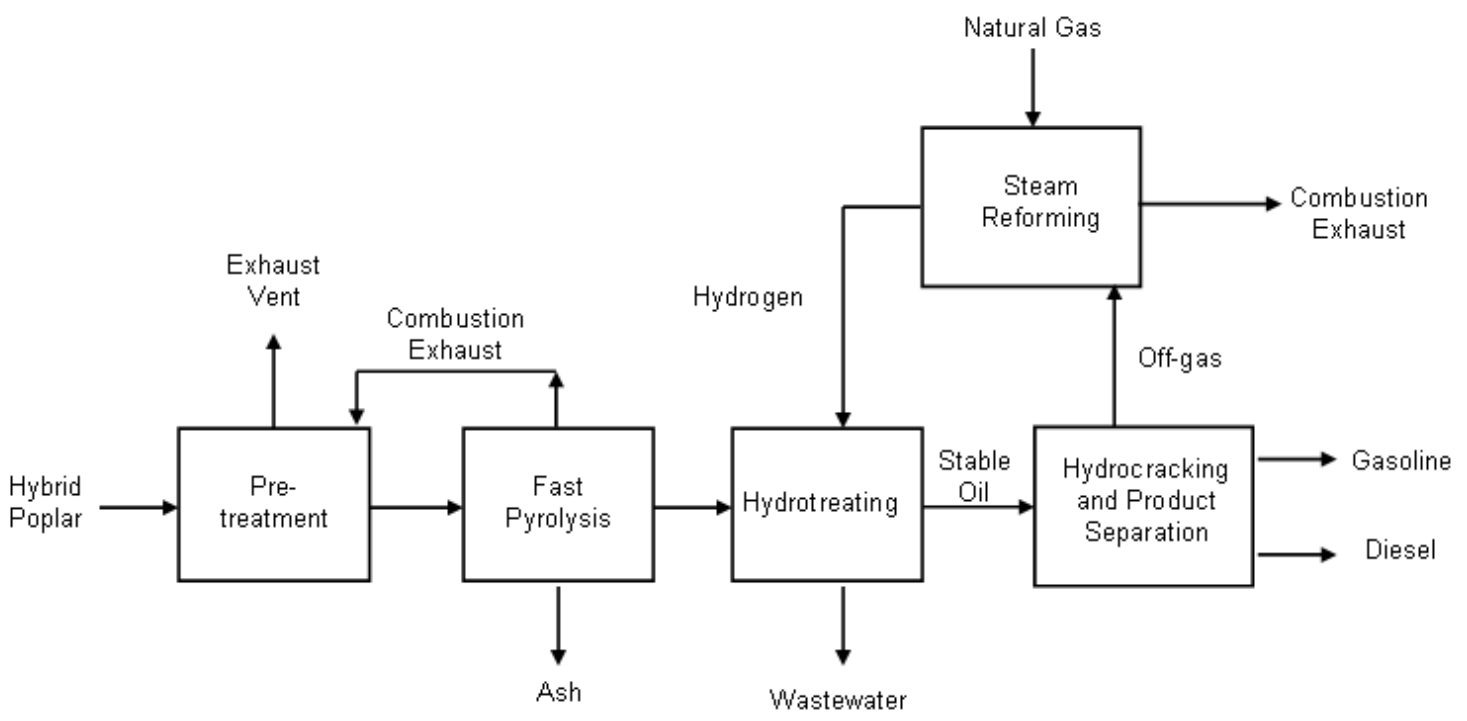

Figure 4.1. Block Diagram of Overall Design

Feed Handling and Preparation: The biomass feedstock is dried from its as-received moisture level to less than $10 \%$ to minimize water in the fast pyrolysis product liquid. It is then ground to 2-6 $\mathrm{mm}$ particle size to yield sufficiently small particles, ensuring rapid reaction in the pyrolysis reactor.

Fast Pyrolysis: Pyrolysis is the thermal decomposition of carbonaceous material in the absence of oxygen to produce char, gas, and a liquid product rich in oxygenated hydrocarbons. In general, pyrolysis is performed using a range of temperatures and residence times to optimize the desired product.

Figure 4.2 illustrates the approximate yields from different modes of pyrolysis (Bridgewater 2007).

Fast pyrolysis is assumed in this work. The biomass is heated to approximately $500^{\circ} \mathrm{C}$ in less than 1 second, and then rapidly cooled to stop the reaction. The liquid product, known as bio-oil, is obtained in yields up to $75 \%$ by weight on a dry feed basis. It can also be upgraded to lower the oxygen content and transported using the same trillion-dollar infrastructure used by the oil industry. In addition to being transported and stored at a lower cost than solid biomass, bio-oil and upgraded oil can be used in applications ranging from value-added chemicals to transportation fuels. 


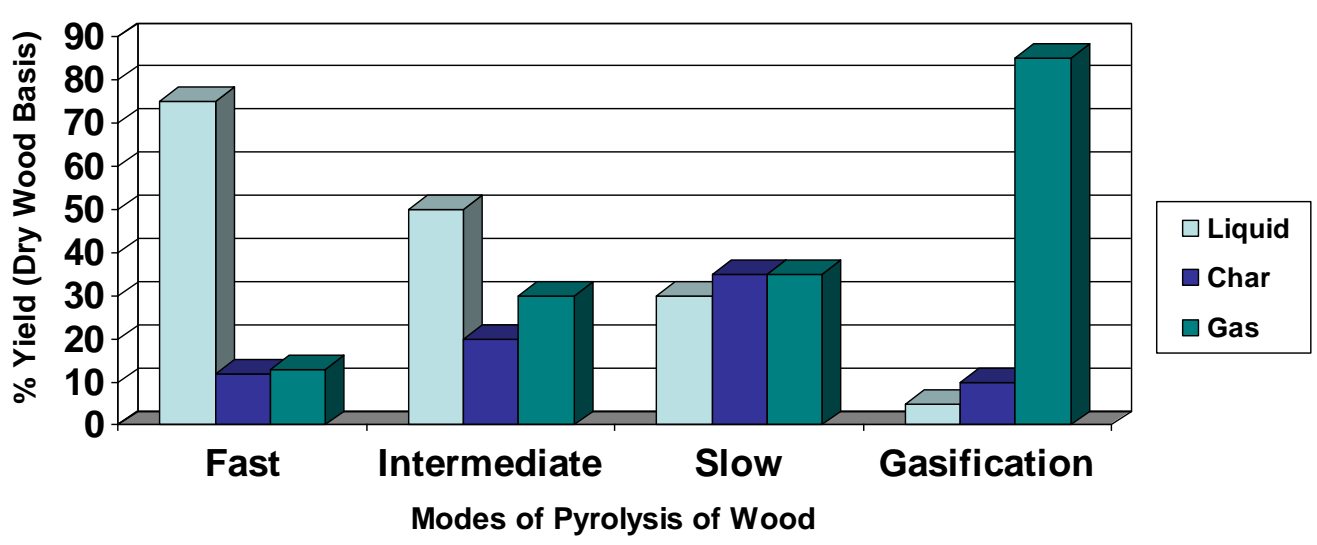

Figure 4.2. Typical Product Yields from Different Modes of Wood Pyrolysis

There are many types of pyrolysis reactor configurations, each with different advantages and disadvantages. The following paragraphs summarize the various reactor types:

- Ablative pyrolysis: Mechanical pressure is used to press carbonaceous material (usually wood) against a heated reactor wall. Material in contact with the wall essentially "melts" and, as it is moved away, the residual oil evaporates as pyrolysis vapors. There is no requirement for inert gas in this configuration, so processing equipment (on demonstration scales) can be smaller and potentially less expensive. The other advantage to this configuration is that feed materials do not require extensive grinding to achieve particle sizes sufficient for high heating rates. Conversely, this configuration is surface-area controlled so scaling is a linear function of the heat-transfer area and does not benefit from the same economies of scale as the other systems. The system is also slightly more complex due to the mechanical nature of the process. There is currently a 50 tpd demonstration plant using this technology in Germany. (Bridgewater 2007)

- Moving Bed or Auger Pyrolysis: This reactor utilizes a screw to mix hot sand and biomass. While it provides good control of residence times and does not dilute the products with fluidizing gas, the sand must be reheated separately, which leads to mechanical reliability issues. There are currently no large-scale commercial plants. (Bridgewater 2007)

- Entrained Flow Pyrolysis: This reactor configuration is popular for studies of thermochemical conversion kinetics and investigations of the effects of pressure. Feed material is typically fed into the top of the reactor, co-current with a gas stream. The flow through this configuration is assumed to approximate plug flow, with the residence time controlled by the length of the heated zone. Char buildup can be a troublesome trade-off for these simple and inexpensive reactors. Liquid yields are usually lower than fluid bed systems. (Bridgewater 2007)

- Rotating Cone: This reactor combines biomass and hot sand at the top of the vessel. The solids are mixed by a rotating cone inside the vessel. Hot pyrolysis oil vapors leave near the bottom of the reactor, while hot sand and char exit the reactor from the bottom of the cone. No carrier gas is needed, resulting in smaller downstream equipment. A 2 mtpd plant operating on palm oil empty fruit bunches was commissioned in Malaysia in 2006. (BTG 2009)

- Bubbling Fluidized Bed Pyrolysis: Here, biomass is introduced to hot sand fluidized by recirculated product gas. This technology is well understood, simple to construct and operate (on large scales), and very efficient in transferring heat to the biomass, resulting in high liquid yields. Small biomass 
particle sizes are required for this method in order to obtain high heating rates. Dynamotive currently operates two plants, one $100 \mathrm{mtpd}$ and one $200 \mathrm{mtpd}$, in Canada. (Bridgewater 2007, Dynamotive 2007)

- Circulating Fluidized Bed Pyrolysis: Similar to bubbling fluidized beds, these configurations circulate hot sand between the pyrolysis reactor and a sand re-heater. Char or product gas and char are burned to provide heat to the sand re-heater. Circulating fluid beds (CFBs) are widely used at very high throughputs in the petroleum industry and are potentially suitable for large biomass throughputs as well. Ensyn operates a 100 tpd (200 tpd green wood) plant in Canada. (Bridgewater 2007, Ensyn 2009)

Both fluidized bed configurations allow for greater control of vapor residence time, an important consideration for optimization of the high liquid yield associated with fast pyrolysis. A circulating fluidized bed was chosen, as this design is the most likely to be scalable to the $2000 \mathrm{mtpd}$ feed rate assumed in this report.

\subsection{Fast Pyrolysis Oil Upgrading}

Untreated bio-oil is a dark brown, free-flowing liquid with about $25 \%$ water that cannot be easily separated. It is a complex mixture of oxygenated compounds that is unstable in long-term storage (Oasmaa and Kuoppala 2003, Diebold 2000) and is not miscible with any conventional hydrocarbonbased fuel (Bridgewater 2007). Bio-oil can be stabilized and converted to a conventional hydrocarbon fuel by removing the oxygen through hydrotreating. Hydrotreating to remove nitrogen and sulfur from hydrocarbons is a common and well established refinery process. Oxygen removal on the scale needed to upgrade pyrolysis oil is relatively new and is in the research stages.

The upgrading step involves contacting the bio-oil with hydrogen under pressure and at moderate temperatures $\left(<400^{\circ} \mathrm{C}\right.$ or $\left.750^{\circ} \mathrm{F}\right)$ over fixed bed reactors. Single stage-hydrotreating has proved to be difficult, producing a heavy, tar-like product. Dual-stage processing, where mild hydrotreating is followed by more severe hydrotreating has been found to overcome the reactivity of the bio-oil (Elliot 2007). Overall, the pyrolysis oil is almost completely deoxygenated by a combination of hydrodeoxygenation and decarboxylation:

$$
\begin{aligned}
& \mathrm{C}_{\mathrm{n}} \mathrm{COOH} \stackrel{\text { Catalyst } / 3 \mathrm{H}_{2}}{\longrightarrow} \mathrm{C}_{\mathrm{n}+1}+2 \mathrm{H}_{2} \mathrm{O} \quad \text { Hydrodeoxygenation } \\
& \mathrm{C}_{\mathrm{n}} \mathrm{COOH} \stackrel{\text { Catalyst } / \mathrm{H}_{2}}{\longrightarrow} \mathrm{C}_{\mathrm{n}}+\mathrm{CO}_{2} \quad \text { Decarboxylation }
\end{aligned}
$$

Less than $2 \%$ oxygen remains in the treated, stable oil. Water and off-gas are produced as byproducts. The water phase contains some dissolved organics, while the off-gas contains light hydrocarbons, excess hydrogen, and carbon dioxide.

Once stabilized oil is produced it can be further processed into conventional fuels or sent to a refinery. Both options are considered in this report. 


\subsection{Process Design}

The design case assumes a standalone unit that combines feed pretreatment, fast pyrolysis, hydrotreating and hydrocracking of pyrolysis oil and separation to gasoline and diesel fuel blendstocks, and hydrogen generation.

\subsection{Feed Handling and Fast Pyrolysis}

Figure 5.1 shows the block diagram for the feed pretreatment, fast pyrolysis, and bio-oil quenching area. Hybrid poplar is dried from its 'as received (AR)' moisture level of $50 \mathrm{wt} \%$ to $7 \mathrm{wt} \%$ water using hot flue gases from the char combustor in a direct-contact dryer. It is then ground to approximately 2-6 $\mathrm{mm}$.

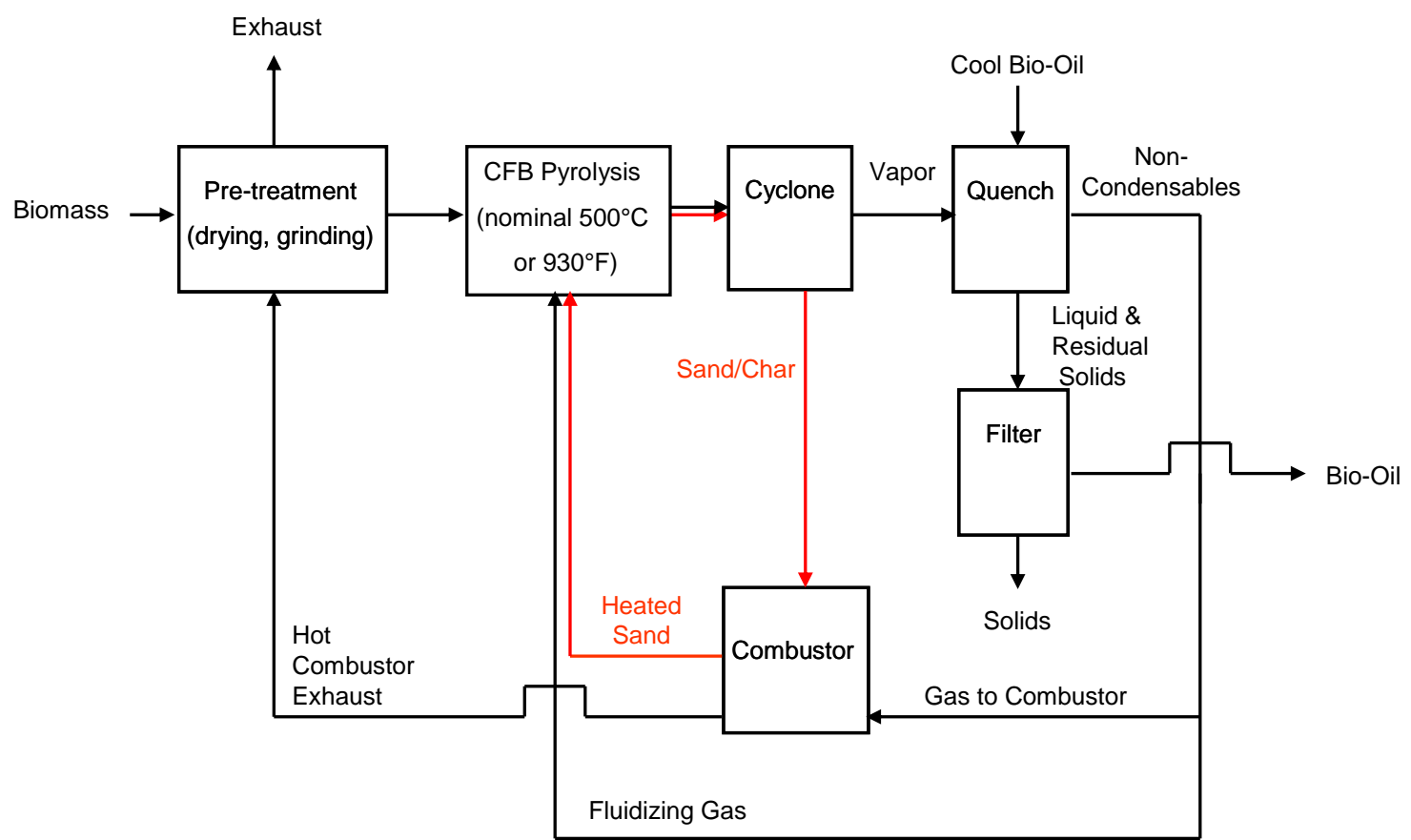

Figure 5.1. Block Diagram of Fast Pyrolysis

Table 5.1 summarizes the as received feedstock characteristics and feed requirements.

The dried, finely ground biomass is fed to a circulating fluidized pyrolysis reactor operating at $520^{\circ} \mathrm{C}$. Sand is used as the fluidizing medium and the residence time is less than a second. The biomass is converted into a mixture of gases, bio-oil, and char. A cyclone separates the sand and char from the gases and liquids. The hot bio-oil vapor is rapidly quenched with cooled bio-oil and then separated from the remaining vapors (Solantausta 2003, Freel and Graham 1995). High temperature heat recovery is not included due to the likelihood of severe fouling in the recuperators (Johnson et al. 2006). Most of the gases are recycled back to the pyrolysis reactor to assist fluidization. The char and a portion of the gas are burned to heat the circulating sand. The cooled pyrolysis oil contains about $20-25 \%$ associated water. 
Table 5.2 shows the product characterization. Note that the bio-oil yield is near the high end of the references. This choice is based on the assumption that improvements in bio-oil yield can be achieved by the 2015 time-frame.

Table 5.1. Feedstock and Processing Assumptions

\begin{tabular}{lc}
\hline & Assumed Value \\
\hline Hybrid Poplar Wood Chips & \\
AR Moisture, wt $\%$ & $50 \%$ \\
wt\% Carbon (dry) & $50.60^{(\mathrm{a})}$ \\
wt\% Hydrogen (dry) & $6.08^{(\mathrm{a})}$ \\
wt\% Oxygen (dry) & $40.75^{(\mathrm{a})}$ \\
wt\% Nitrogen (dry) & $0.61^{(\mathrm{a})}$ \\
wt\% Sulfur (dry) & $0.02^{(\mathrm{a})}$ \\
wt\% Chlorine (dry) & $0.01^{(\mathrm{a})}$ \\
wt\% Ash (dry) & $1.93^{(\mathrm{a})}$ \\
HHV, Btu/lb & $8405^{(\mathrm{a})}$ \\
Temperature, ${ }^{\circ} \mathrm{F}\left({ }^{\circ} \mathrm{C}\right)$ & $968(520)^{(\mathrm{b})}$ \\
Pressure & atmospheric \\
Feed Moisture to pyrolysis unit, wt $\%$ & $7^{(\mathrm{b})}$ \\
\hline (a) Hybrid Poplar. Phyllis Database for Biomass and Waste \\
(b) Solantausta 2003
\end{tabular}

Table 5.2. Product Characterization

\begin{tabular}{lccc}
\hline & Model Results & Reference Data $^{(\mathrm{a})}$ & Reference Data $^{(\mathrm{b})}$ \\
\hline Yields, lb/100 lb dry wood & 65 & 59.9 & 66 \\
Oil & 10 & 10.8 & 12 \\
Water & 13 & 16.2 & 8 \\
Char \& Ash & 12 & 13.1 & 11 \\
Gas & & & 3 \\
Loss & & & \\
Oil Composition & 21 & $15-30$ & \\
Water in oil, wt $\%$ & 58 & $55-58$ & \\
Carbon, wt $\%$ dry & 6 & $5.5-7.0$ & \\
Hydrogen, wt $\%$ dry & 36 & $35-40$ & \\
Oxygen, wt $\%$ dry & & & \\
\hline
\end{tabular}

(a) Ringer et al. 2006

(b) Mohan et al. 2006 
The detailed model flowsheet diagram and associated heat and material balance for the fast pyrolysis section can be found in Appendix A.

\subsection{Hydrotreating to Stable Oil}

The simplified flow diagram for the stand-alone upgrading portion of the plant is shown in Figure 5.2.

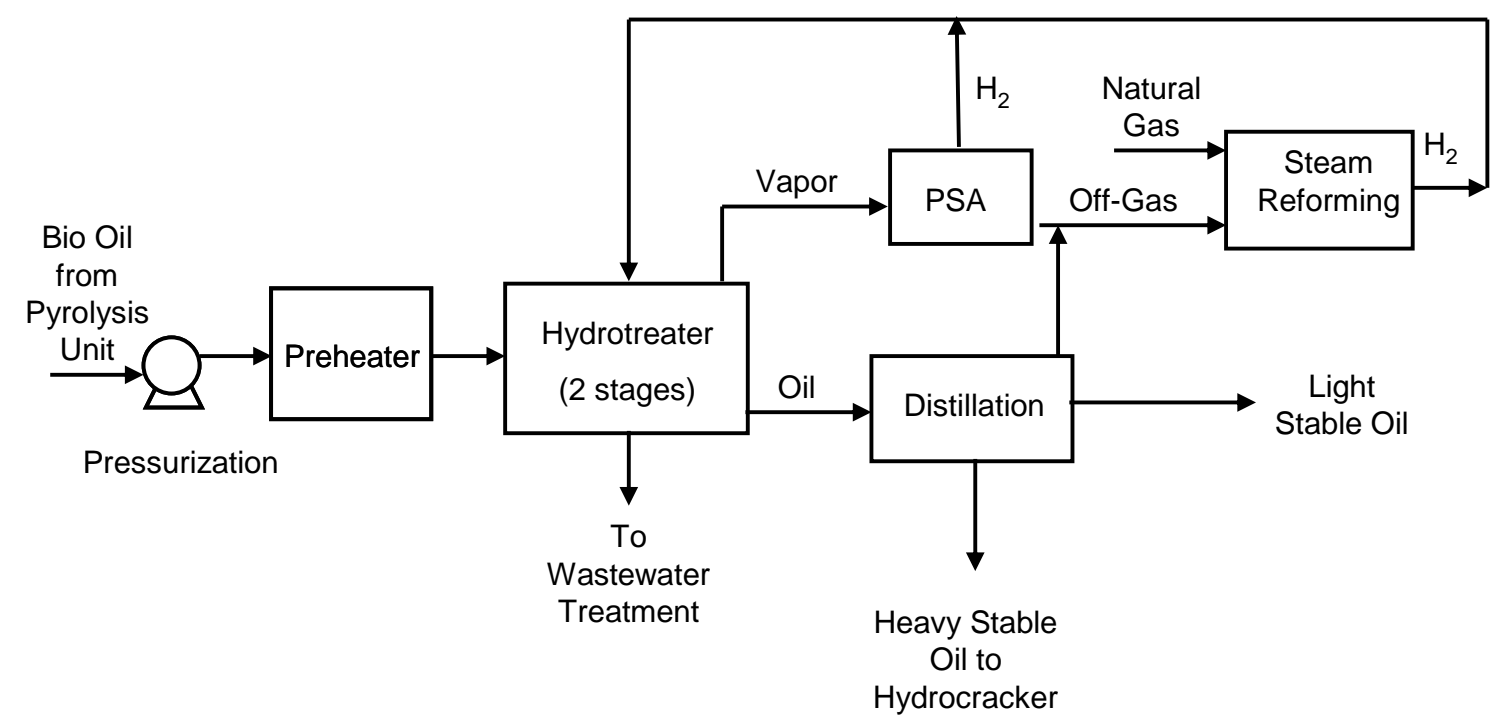

Figure 5.2. Block Diagram of Bio-Oil Upgrading

The filtered bio-oil product from the pyrolysis unit is pumped to high pressure, then combined with compressed hydrogen and preheated with reactor effluent. Two catalytic reaction stages are used. The first stage catalytic reactor serves to stabilize the bio-oil by mild hydrotreatment over cobalt molybdenum (CoMo) hydrotreating catalyst (Elliott 2007). The product oil is further processed in the second-stage hydrotreater. The second stage hydrotreater operates at higher temperature and lower space velocity than the first stage. CoMo catalyst is also used in this reactor. Reactor effluent and a fired heater provide feed preheat for the second stage. The second-stage product is separated into product oil, wastewater, and offgas streams.

The off-gas from the hydrotreaters is sent to a Pressure Swing Adsorption (PSA) system for recovery of the hydrogen gas. The recovered hydrogen is recycled back to the reactors. The low pressure PSA tail gas stream, which is rich in byproduct light hydrocarbons, is sent to the steam reformer for hydrogen production. A small portion of this off-gas is used in the fired heater that preheats feed for the secondstage hydrotreater.

Anaerobic digestion can be used to treat the less than $2 \%$ organics in the wastewater.

The processing conditions are listed in Table 5.3. The product oil is a mixture of hydrocarbons with a low level ( $2 \%$ ) of oxygen, as shown in Table 5.4. Data from Beckman et al. (1990) and Elliot (2007) were used to estimate the product slate. 
Table 5.3. Hydrotreating Conditions

\begin{tabular}{lcc}
\hline & $1^{\text {st }}$ Stage $^{(\mathrm{a})}$ & $2^{\text {nd }}$ Stage $^{(\mathrm{a})}$ \\
\hline Temperature, ${ }^{\circ} \mathrm{F}\left({ }^{\circ} \mathrm{C}\right)$ & $465(240)$ & $700(370)$ \\
Pressure, $\mathrm{psig}$ & 2500 & 2015 \\
LHSV, $\mathrm{v} / \mathrm{h} / \mathrm{v}$ & 1 & 0.14 \\
\hline (a) Beckman et al 1990 & &
\end{tabular}

Table 5.4. Hydrotreating Product Yields

\begin{tabular}{lccc}
\hline & Model & $\begin{array}{c}\text { Reference } \\
\text { Data }^{\text {(a) }}\end{array}$ & $\begin{array}{c}\text { Reference } \\
\text { Data }^{(\mathrm{b})}\end{array}$ \\
\hline Yields, lb /100 lb wet pyrolysis oil & & & 38 \\
$\quad$ Stable Oil (Stream 304) & 44 & & 50 \\
$\quad$ Water (Stream 230) & 48 & & 12 by difference \\
$\quad$ Gas (Streams 270 and 302) & 13 & & 3.45 \\
Chemical H2 Consumption, lb/100 lb dry oil & 4.96 & 5.01 & \\
Stable Oil Composition (Stream 304) & & & 0 \\
$\quad$ Water, ppm & 0 & 50 & Not reported \\
$\quad$ Aromatics, wt\% & & 10.0 & 10.8 \\
$\quad$ Carbon, wt\% dry & 88.1 & 86.8 & 2.5 \\
$\quad$ Hydrogen, wt\% dry & 10.5 & 13.2 & 0.93 \\
$\quad$ Oxygen, wt\% dry & 1.5 & 0.02 & 17,302 \\
Specific Gravity & 0.87 & 0.83 & 16,276 \\
Btu/lb, gross & 17,600 & 19,765 & \\
Btu/lb, net & 16,600 & 18,525 & \\
\hline (a) Tables 15 \& 16 in Elliot 2007 & & & \\
(b) Beckman et al. 1990, Chapter 5 & & & \\
\hline
\end{tabular}

\subsection{Hydrocracking and Product Separation}

Figure 5.3 shows the simplified flow diagram for the hydrocracking and product separations areas. The hydrotreated oil is stabilized by removing the butane and lighter components in a lights removal column. The stable oil stream is then separated into light and heavy fractions. The heavy fraction (which boils above $350^{\circ} \mathrm{C}\left(662^{\circ} \mathrm{F}\right)$ is sent to the hydrocracker to completely convert the oil to gasoline and diesel blend components. 


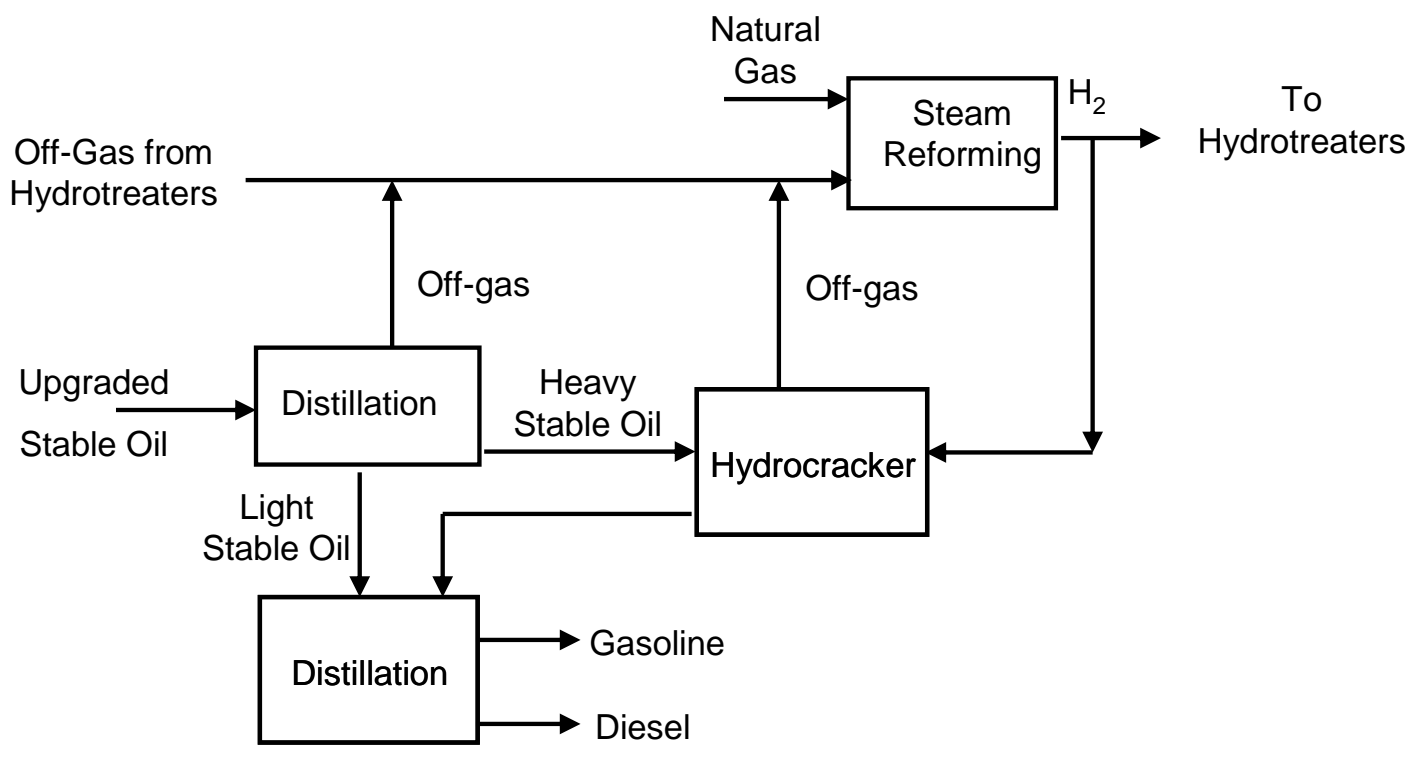

Figure 5.3. Block Diagram of Hydrocracking and Product Separation

The product is a mixture of liquids spanning the gasoline and diesel range and some byproduct gas. The gasoline and diesel range products are separated by distillation. These products are suitable for blending into finished fuel. The hydrocracking conditions and product yields are shown in Table 5.5.

Table 5.5. Hydrocracking Conditions

\begin{tabular}{lcc}
\hline & Model & Reference Data \\
\hline Nominal Temperature, ${ }^{\circ} \mathrm{F}\left({ }^{\circ} \mathrm{C}\right)$ & $800(427)$ & $775(413)^{(\mathrm{a})}$ \\
Pressure, psig & 1280 & $1051($ mild $)-2400($ resid $)$ \\
Gasoline, lb/100 lb feed & 95 & Depends on feed/conditions \\
Diesel,, $\mathrm{b} / 100 \mathrm{lb}$ feed & 5 & Depends on feed/conditions ${ }^{(\mathrm{a}, \mathrm{b})}$ \\
\hline (a) Parkash 2003 & & \\
(b) Gulf 2006 & & \\
\hline
\end{tabular}

\subsection{Hydrogen Production}

Figure 5.4 shows the simplified flow scheme for hydrogen generation by steam reforming of natural gas (SRI International 2007, Meyers 2004) and the off-gas streams from the hydrotreating and hydrocracking processes. The off-gas by itself is insufficient to produce the amount of hydrogen required by the hydrotreaters and hydrocrackers; supplemental natural gas is required. Most of the off-gas is used to fire the reformer; however, a portion of the off-gas is compressed and mixed with makeup natural gas which is then hydrodesulfurized (HDS). Hydrogen for the HDS unit is supplied by the off-gas stream. The gas exiting the HDS is then mixed with superheated steam and sent to the steam reformer to produce syngas. The syngas hydrogen content is increased by high temperature shift (HTS). After condensing out the water, the hydrogen is purified by pressure swing adsorption (PSA). Off-gas from the PSA is recycled to the reformer burners. 


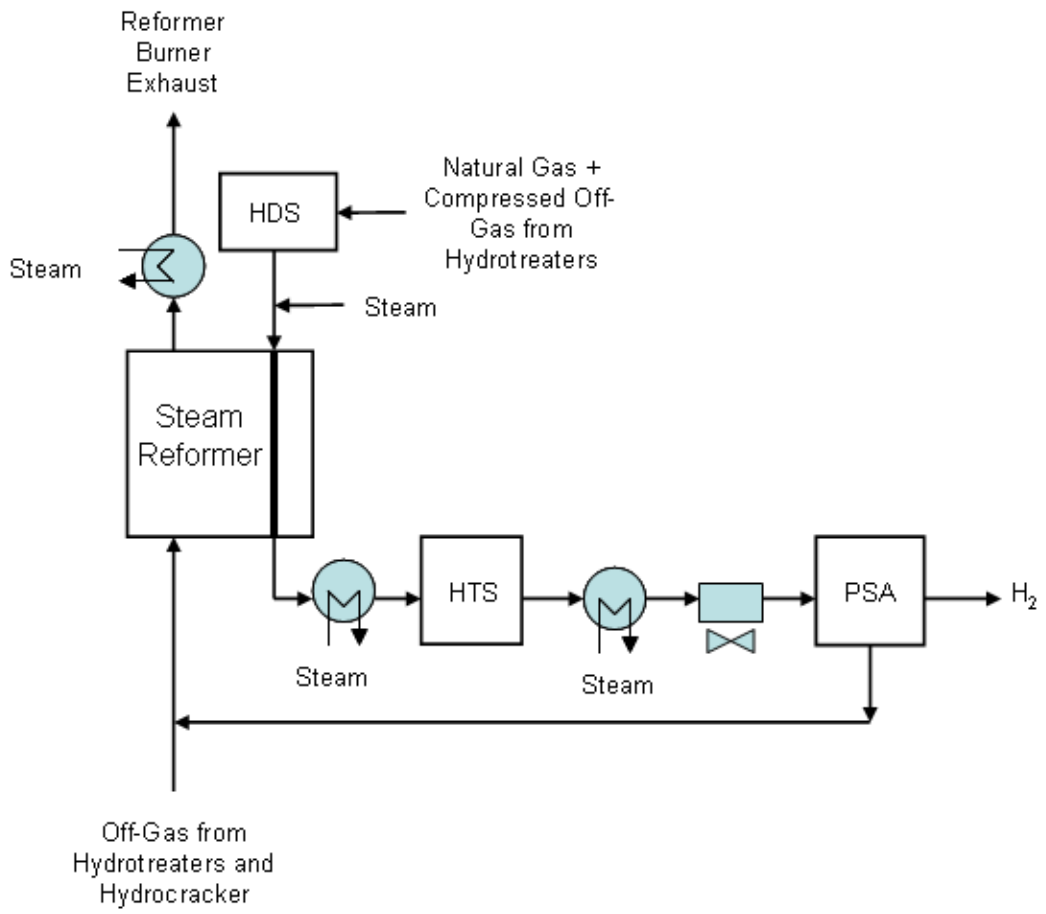

Figure 5.4. Block Diagram of Hydrogen Production

Saturated and superheated steam are generated by recuperating heat from the reformer exhaust and during syngas cooling. The steam is used to provide steam to the reformer and heat for process heaters and distillation column reboilers. A steam export credit is taken for the small amount of excess steam not used by the process. The heat and material balance for the steam reformer can be found in Appendix A.

\subsection{Cooling Water and Utilities}

Cooling water usage is minimized through the use of air fin coolers where applicable. The process water demands are shown in Table 5.6. Most of the cooling tower water is used to indirectly cool the fast pyrolysis bio-oil that is recirculated in the quench system. Optimizing the quench process could reduce this value further. For example, chillers could supply some of the cooling, however this would increase the power demand. Electricity is bought from the grid; no power is generated onsite. Waste water is treated in an onsite facility before discharge.

Table 5.6. Process Water Demands

\begin{tabular}{lc}
\hline Source of Water Demand & Model \\
\hline Cooling tower makeup, gpm & 373 \\
Steam reformer boiler feed water makeup, gpm & 113 \\
Total, gpm & 486 \\
Overall demand, gal water/gal product & 3.0 \\
\hline
\end{tabular}




\subsection{Process Yields and Consumptions}

The yield of product fuel from wood is shown in Table 5.7. The unadjusted yield, shown in the first row of Table 5.7, does not take into account the natural gas used in steam reforming for hydrogen production. It is of interest to know what the yield of fuel products would be if only renewable feedstocks were used. In the base case, hydrogen for the upgrading reactors is generated in a conventional steam reformer using offgas from the upgrading reactors plus natural gas. This hydrogen could also be derived from renewable resources, for example by 1) gasifying biomass, then shifting the syngas to hydrogen or by 2) steam reforming a portion of the fast pyrolysis oil. It is estimated that if the natural gas used to generate hydrogen was replaced by biomass or bio-oil, approximately one third of the biomass feedstock would be needed for hydrogen generation. The yield of fuel products on a $100 \%$ renewable basis is shown in the second row of Table 5.7. The third row of Table 5.7 shows the $100 \%$ renewable yield on an ethanol equivalent basis (lower heating value (LHV) adjusted). Table 5.7 also summarizes water, power and NG consumption.

Table 5.7. Overall Yields and Consumption

\begin{tabular}{lc}
\hline & Model \\
\hline Fuel Product, gal/st dry wood - unadjusted for natural gas usage in the reformer & 100 \\
Fuel Product, gal/st dry wood - adjusted to 100\% renewable feedstock basis & 65 \\
LHV ethanol equivalent Fuel Product, gal/st dry wood, 100\% renewable basis & $\sim 100$ \\
Gallons makeup water/gallons fuel product & 3.0 \\
Power, kWh/gallon fuel product & 2.5 \\
Natural Gas, scf/gallon fuel product & 42 \\
\hline
\end{tabular}

Table 5.8 shows the carbon balance. More than half of the carbon in the combined biomass plus natural gas feed is converted into fuel products.

Table 5.8. Carbon Balance

\begin{tabular}{llr}
\hline Feeds & Biomass & $88 \%$ \\
& Natural Gas & $12 \%$ \\
Fuel Products & Gasoline Pool & $100 \%$ \\
& Diesel Pool & $23 \%$ \\
& & $32 \%$ \\
Waste Products & Pyrolysis Unit Exhaust & $55 \%$ \\
& Upgrading Wastewater & $23 \%$ \\
& Upgrading Heaters Exhaust & $2 \%$ \\
& Reformer Exhaust & $20 \%$ \\
& & $45 \%$ \\
\hline
\end{tabular}

The heat and material balance for the Stand-Alone Design Case is located in Appendix A. 


\subsection{Process Economics}

\subsection{Capital Costs}

The cost basis assumes that this is the $\mathrm{n}^{\text {th }}$ plant. Capital costs for the pyrolysis unit, the hydrocracker unit, and the hydrogen plant are from literature sources. The heat and material balance was used to size standard equipment using $\mathrm{CHEMCAD}^{\odot}$ sizing routines or by using standard literature sources (Perry et al. 1984, Couper et al. 2005). ASPEN Icarus ${ }^{\mathrm{TM}}$ was used to obtain bare equipment costs for sized equipment. The 2007 annual Chemical Engineering Index was used to escalate capital costs to 2007. Equipment sizing and cost sources are summarized below. Additional details can be found in Appendix B.

\subsubsection{Pyrolysis Unit}

Existing pyrolysis units process 200 tpd of biomass or less, and capital cost data is limited. This report used data from Ringer et al. 2006, scaled to 2000 tpd. Costs associated with feed handling, pyrolysis reactor, quench, and product recovery were included. Heat recovery and power generation were excluded. The 35\% equipment contingency used in Ringer et al. 2006 was retained. As seen in Table 6.1 , these costs are within the average of the data shown.

Table 6.1. Pyrolysis Unit Literature Capital Cost

\begin{tabular}{|c|c|c|c|c|c|}
\hline $\begin{array}{l}\text { Study } \\
\text { Date }\end{array}$ & $\begin{array}{c}\text { Original Scale, } \\
\text { mtpd }\end{array}$ & $\begin{array}{c}2007 \text { TIC MM\$ } \\
\text { at } 2000 \text { tpd }\end{array}$ & $\begin{array}{c}\text { Power, } \\
\text { kW-h/tonne }\end{array}$ & Source & Notes \\
\hline 2003 & 96 & 68.7 & 40 & (a) & Cost for 5 96-tpd units \\
\hline 2003 & 490 & 55.5 & 156 & (b) & Estimated from 40-60 MWth data \\
\hline 2007 & 200 & 48.5 & & (c) & Dynamotive Plant \\
\hline 2006 & 550 & 44.5 & 192 & (d) & TIC includes $35 \%$ equipment contingency \\
\hline 1990 & 1001 & 33.7 & & (e) & 20 fluidized beds @ 100 tpd level \\
\hline 2003 & 500 & 39.2 & 156 & (b) & Estimated from 15-140 MWth data \\
\hline 2003 & 96 & 35.5 & & (f) & Cost scaled with $6 / 10$ rule \\
\hline 1990 & 1001 & 27.1 & 167 & (e) & 1 circulating fluidized-bed pyrolysis unit \\
\hline $\begin{array}{l}\text { (a) Brid } \\
\text { (b) Sola } \\
\text { (c) Dyn } \\
\text { (d) Ring } \\
\text { (e) Becl } \\
\text { (f) John }\end{array}$ & $\begin{array}{l}\text { sewater et al } 2002 \\
\text { tausta } 2003 \\
\text { motive } 2007 \\
\text { er et al } 2006 \\
\text { man et al } 1990 \\
\text { on et al } 2006\end{array}$ & & & & \\
\hline
\end{tabular}

\subsubsection{Pyrolysis Oil Hydrotreating and Hydrocracking}

Most of the equipment for this section were sized using CHEMCAD $^{\odot}$ and costed using ASPEN Icarus $^{\mathrm{TM}}$ or taken from vendor budgetary quotes. The cost of a small hydrocracker system processing hydrotreated bio-oil has been estimated by UOP (Marker et al. 2005). The large-diameter, high-pressure hydrotreater vessels are likely to be manufactured outside of the United States. A 15\% equipment contingency was added to account for uncertainty in the fabrication and hydrocracker unit costs. 


\subsubsection{Hydrogen Generation}

Hydrogen generation by steam reforming of natural gas is a well-known, mature process; therefore no equipment contingency was added. The SRI Yearbook (SRI International 2007) and Foster Wheeler (Gulf 2006, Meyer 2004) have published capital and operating data for plants of various capacities.

\subsubsection{Balance of Plant}

Storage capacity and cooling tower capital were estimated with ASPEN Icarus. Wastewater treatment costs are from Beckman et al. 1990. A 15\% process contingency was added.

Table 6.2 and Table 6.3 list the stand-alone design case installed equipment capital costs and the factors used to determine the total project investment, respectively. The factors in Table 6.2 are from Peters et al (2003).

Table 6.2. Total Project Investment Cost for the Design Case Stand-Alone Plant

\begin{tabular}{lcc}
\hline & 2007 MMUSD & \% Contribution \\
\hline Fast Pyrolysis & 92 & $30 \%$ \\
Hydrotreating & 81 & $27 \%$ \\
Hydrocracking and Separations & 29 & $10 \%$ \\
Hydrogen Generation & 86 & $28 \%$ \\
Utilities, etc. & 14 & $5 \%$ \\
& $303 *$ & 100 \\
* Summation higher due to rounding & & \\
\hline
\end{tabular}

Table 6.3. Total Project Investment Factors

\begin{tabular}{lrl}
\hline Total Purchased Equipment Cost (TPEC) & $100 \%$ & \\
Purchased Equipment Installation & $39 \%$ & of TPEC \\
Instrumentation and Controls & $26 \%$ & of TPEC \\
Piping & $31 \%$ & of TPEC \\
Electrical Systems & $10 \%$ & of TPEC \\
Buildings (including services) & $29 \%$ & of TPEC \\
Yard Improvements & $12 \%$ & of TPEC \\
Total Installed Cost (TIC) & $247 \%$ & \\
Indirect Costs & & \\
Engineering & $32 \%$ & of TPEC \\
Construction & $34 \%$ & of TPEC \\
Legal and Contractors Fees & $23 \%$ & of TPEC \\
Project Contingency & $37 \%$ & of TPEC \\
Total Indirect & $126 \%$ & \\
Total Project Investment & $373 \%$ & \\
\hline
\end{tabular}




\subsection{Operating Costs}

Table 6.4 lists the assumptions used to calculate the operating costs. Catalyst costs were escalated with the average Producer Price Index for 2007.

Table 6.4. Operating Cost Assumptions

\begin{tabular}{lc}
\hline & Value \\
\hline Raw Materials & \\
Hybrid Poplar Chips, \$/dry short ton & 50.70 \\
Ash Disposal, \$/short ton & $18^{(\mathrm{a})}$ \\
Hydrogen (refinery transfer), \$/lb & $0.56^{(\mathrm{b})}$ \\
Hydrotreating Catalyst, \$/lb (2007) & $15.5^{(\mathrm{c})}$ \\
Hydrocracking Catalyst, \$/lb (2007) & $15.5^{(\mathrm{c})}$ \\
Hydrogen Plant Catalysts, \$/1000 scf $\mathrm{H}_{2}(2007)$ & $3.6^{(\mathrm{c})}$ \\
& \\
Utilities & \\
Natural Gas, \$/1000scf (1000 Btu/scf) & $7.68^{(\mathrm{d})}$ \\
Electricity, $\$ /$ kwh & $6.36^{(\mathrm{d})}$ \\
& \\
Labor & \\
Operating labor, \$/hr burdened \& 10\% shift overlap & $37.66^{(\mathrm{c})}$ \\
Maintenance and overhead & 95\% of labor \& supervision ${ }^{(\mathrm{e})}$ \\
Materials & \\
Maintenance & investment \\
Local taxes \& insurance & \\
\hline (a) Phillips et al. 2007 of total project investment \\
(b) Holmgren et al. 2007 \\
(c) SRI International 2007 \\
(d) Energy Information Agency 2007 \\
(e) Phillips et al. 2007
\end{tabular}

\subsection{Minimum Fuel Selling Price}

The minimum fuel product selling price (MFSP) for the gasoline and diesel blendstock was determined using a discounted cash flow rate of return analysis. The methodology is identical to that used in Phillips et al. (2007). The MFSP is the selling price of the fuel that makes the net present value of the process equal to zero with a $10 \%$ discounted cash flow rate of return over a 20 year plant life. The stream factor (90\%) is lower than that used in Phillips et al. (2007) to account for the shorter catalyst life (1 year versus 5) assumed in this study. While two products are produced, (motor gasoline blendstock and diesel 
blendstock), they are combined and referred to as a "fuel product" for simplicity. All MFSP calculations are performed and reported on a combined product basis. Table 6.5 gives the economic parameters used to calculate the MFSP. A sensitivity analysis was conducted to determine the effect of different financial and operating assumptions on the MFSP.

Table 6.5. Economic Parameters

\begin{tabular}{|c|c|}
\hline & Value \\
\hline Stream Factor & $90 \%$ \\
\hline MACRS Depreciation, yrs & $7^{(\mathrm{a})}$ \\
\hline Internal Rate of Return, $\%$ & $10 \%{ }^{(\mathrm{a})}$ \\
\hline Plant life, yrs & $20^{(\mathrm{a})}$ \\
\hline $\begin{array}{l}\text { Construction Period } \\
1^{\text {st }} 6 \text { months' expenditure } \\
\text { Next } 12 \text { months' expenditure } \\
\text { Last } 12 \text { months' expenditure }\end{array}$ & $\begin{array}{c}2.5 \text { years }^{(\mathrm{a})} \\
8 \%^{(\mathrm{a})} \\
60 \%^{\text {(a) }} \\
32 \%^{(\mathrm{a})}\end{array}$ \\
\hline $\begin{array}{l}\text { Start-up time } \\
\text { Revenues } \\
\text { Variable Costs } \\
\text { Fixed Costs }\end{array}$ & $\begin{array}{c}6 \text { months }^{(\mathrm{a})} \\
50 \% \%^{(\mathrm{a})} \\
75 \%^{(\mathrm{a})} \\
100 \%^{(\mathrm{a})}\end{array}$ \\
\hline Working Capital & $5 \%$ of Total Capital Investment ${ }^{(a)}$ \\
\hline Land & $\begin{array}{l}6 \% \text { of Total Purchased Equipment Cost } \\
{\text { (taken as } 1^{\text {st }} \text { year construction expense) }}^{\text {(a) }}\end{array}$ \\
\hline
\end{tabular}

(a) Phillips et al. 2007

The variable operating costs were determined from the heat and material balances and checked against published data for the hydrocracker and steam reformer. These and the fixed operating costs are shown in Table 6.6. 
Table 6.6. Project Economics for the Stand-Alone Design Case Plant

\begin{tabular}{lcc}
\hline & \$/gal product & Contribution \\
\hline Feedstock & 0.48 & $23 \%$ \\
Natural Gas & 0.32 & $16 \%$ \\
Catalysts \& Chemicals & 0.15 & $7 \%$ \\
Waste Disposal & 0.01 & $0 \%$ \\
Utilities (Cooling Water, Electricity, Steam) & 0.17 & $8 \%$ \\
Fixed Costs (Labor, Operating Supplies, etc.) & 0.22 & $11 \%$ \\
& & \\
Capital Depreciation & 0.20 & $10 \%$ \\
Average Income Tax & 0.13 & $7 \%$ \\
Average ROI & 0.36 & $18 \%$ \\
& & \\
MFSP, \$/gal & 2.04 & \\
MFSP Ethanol Equivalent Basis, \$/gal & 1.34 & \\
\hline
\end{tabular}

The 2007 average refiner prices for gasoline and diesel were \$2.18 and \$2.20 respectively (Energy Information Agency 2007). Thus, at \$2.04/gal fuel product price, there is incentive to pursue motor fuels from biomass. 



\subsection{Economic and Technical Sensitivities}

The design case describes a single operating point for a stand-alone processing unit. This section investigates the production cost sensitivities to technical, financial, and market issues. These include plant size, ROI, feedstock costs, reactor conditions and product yields. Because hydrocarbon fuels are the final product, an important sensitivity is the possibility of co-locating the pyrolysis and upgrading facility with an existing refinery.

\subsection{Co-location with a Refinery}

An alternate configuration to the standalone plant described in Section 5 is a facility that is co-located with an existing refinery. Figure 7.1 shows the design case integrated with a refinery. The pyrolysis unit is the same as in the stand-alone case. Co-location eliminates the need for a PSA unit in the hydrotreating section if the upgrading unit off-gas can be sent to refinery hydrogen generation. In return, the upgrading unit receives refinery hydrogen at a lower cost. All final processing of the stable oil to fuels occurs in the refinery.

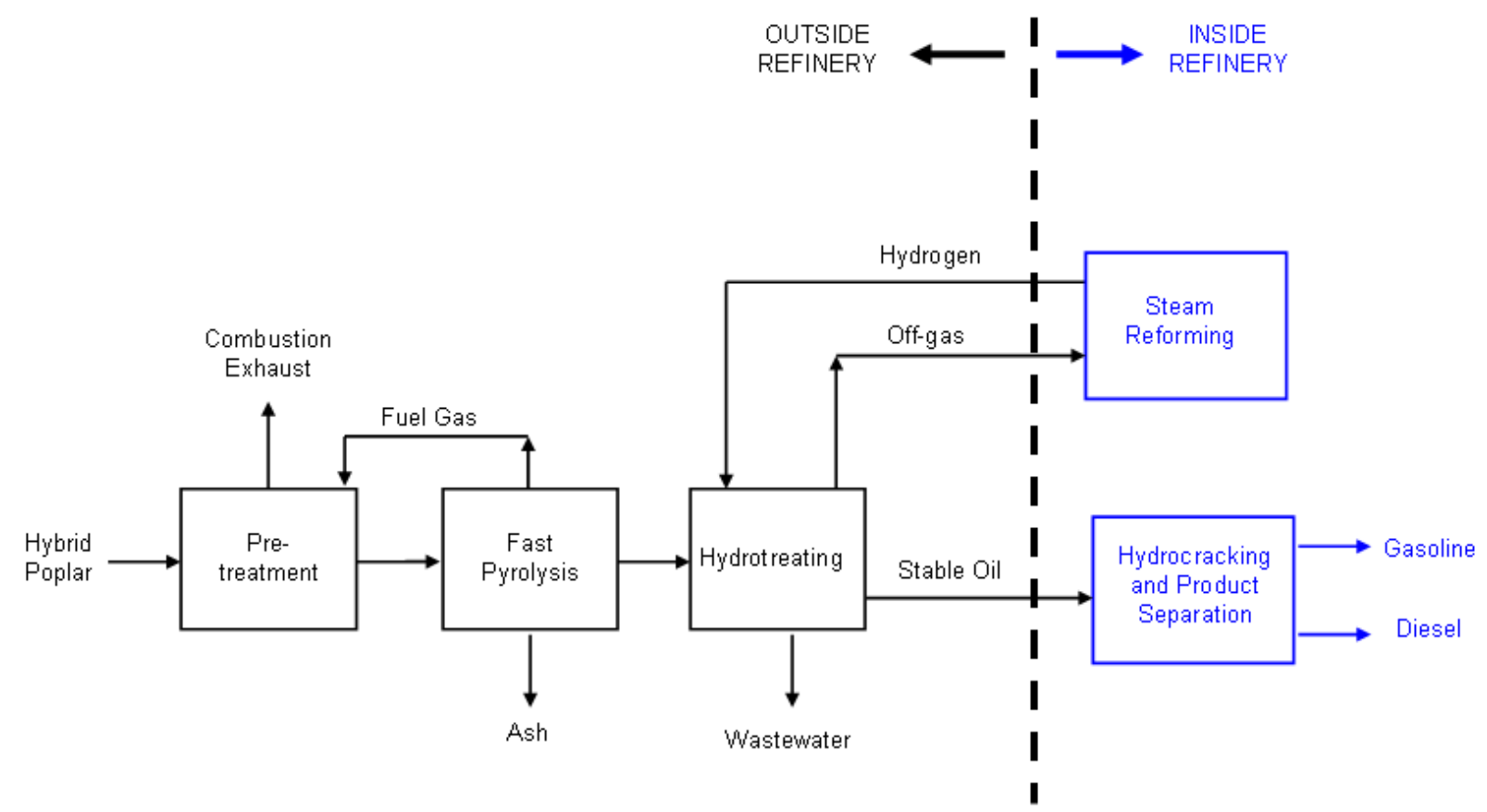

Figure 7.1. Block Diagram of Pyrolysis and Upgrading Plant Co-located with a Refinery

VTT and partners (Solantuasta 2006) and UOP (Marker et al 2005, Holmgren et al 2007) are separately pursuing producing bioproducts compatible with existing refinery infrastructure. This will lessen the initial investment; however, direct use of stable oil in a refinery requires complete deoxygenation and a low acid number to prevent corrosion. As an alternative, a finishing deoxygenation unit and/or a separate hydrotreating/hydrocracking operation using dedicated stainless steel equipment may be needed. The finishing hydrotreating unit may result in saturating aromatic compounds, in which case the light naphtha portion may need to be reformed in the refinery into aromatics before blending into gasoline. 
Table 7.1 compares the stand-alone and integrated economics. The capital cost calculations assume that the refinery equipment is fully depreciated and only operating costs apply to the refinery side. This greatly reduces the capital investment. A hydrogen transfer price of $\$ 0.56 / \mathrm{lb}$ (Holmgren et al 2007) assumes that all operating costs (including feedstock and fuel) to the hydrogen generation unit within the refinery are accounted for in that price. A credit is taken for the fuel gas sent from the upgrading unit to the refinery. The transfer price for the fuel gas to the refinery is determined by adjusting the current price of natural gas for the Btu value of the fuel gas. The product costs are significantly lower than those for the stand-alone plant due to reduced capital investment and the net cost difference between hydrogen and fuel gas.

Table 7.1. Comparison of Integrated and Standalone Facilities

\begin{tabular}{lccc}
\hline & $\begin{array}{c}\text { Capital } \\
\text { Investment, } \\
\text { MM\$ }\end{array}$ & $\begin{array}{c}\text { Minimum Selling } \\
\text { Price \$/gal fuel } \\
\text { product }\end{array}$ & $\begin{array}{c}\text { Minimum Selling } \\
\text { Price \$/gal ethanol } \\
\text { equivalent }\end{array}$ \\
\hline $\begin{array}{l}\text { Stand-Alone Plant - Design } \\
\text { Case }\end{array}$ & 303 & 2.04 & 1.34 \\
\begin{tabular}{l} 
Integrated Plant - Design Case \\
\hline
\end{tabular} & 188 & 1.74 & 1.14 \\
\hline
\end{tabular}

\subsection{Financial and Market Sensitivities}

The sensitivities to financial assumptions are shown in Figure 7.2. Refinery integration with a $\$ 0.56 /$ lb hydrogen transfer price reduces the base case MFSP by about $\$ 0.30 /$ gal. No refining capital costs were assumed. However, operating costs based on the amount of stable oil processed were included. It is possible that some revamping of refinery equipment will be needed to process the stable oil. The cost of modifying a hydrocracker was estimated by assuming that the incurred costs would not be greater than a small hydrocracker dedicated to stable oil. At a $\$ 0.56 / 1 b$ hydrogen transfer price, this option reduces the base MFSP by about $\$ 0.13 /$ gal. Finally, the hydrogen transfer price in an integrated facility was varied by $\$ 0.75 / \mathrm{lb}$ and $\$ 1.25 / \mathrm{lb}$ hydrogen. The MFSP of the integrated facility exceeds that of the base case at hydrogen transfer prices above $\$ 1.00 / \mathrm{lb}$, which is the approximate transfer price for hydrogen if new hydrogen generation facilities must be built.

Sensitivities to project contingency, capital investment, scale and ROI were determined for the standalone case. Reducing the project contingency to three percent of the total capital project, (similar to that used in Phillips et al. 2007), reduces the selling price by about $\$ 0.22 /$ gal. The accuracy of the capital estimate is in the range of $-10 \%$ to $+40 \%$, and gives an MFSP range of $\$ 1.79 /$ gal to $\$ 2.22 /$ gal or a difference of $-0.22 /$ gal to $+\$ 0.20 /$ gal.

The base plant assumes a $90 \%$ stream factor. This may be optimistic with single reactors for fast pyrolysis and upgrading. The equipment spare sensitivity determines the product cost increase if both the pyrolysis unit and upgrading units had 3 reactors at 50\% capacity each. This increases the selling price by about $\$ 0.21 / \mathrm{gal}$.

The cost of a single small pyrolysis with an upgrading unit at 500 tpd increases the selling price to almost $\$ 2.68 /$ gal. Four 500 tpd units feeding a single upgrading unit is more cost effective, assuming the feedstock cost is the same for both cases. The cost of transporting biomass feedstock is a limiting factor 
in the size of a biomass processing plant. It is possible that small, distributed pyrolysis plants can take advantage of lower feedstock costs and produce an easily transported product that can then be upgraded to fuel in a large, centralized facility. Further analysis is needed to look at the tradeoff between pyrolysis plant size and feedstock cost, and the transportation costs to a centralized upgrading plant.

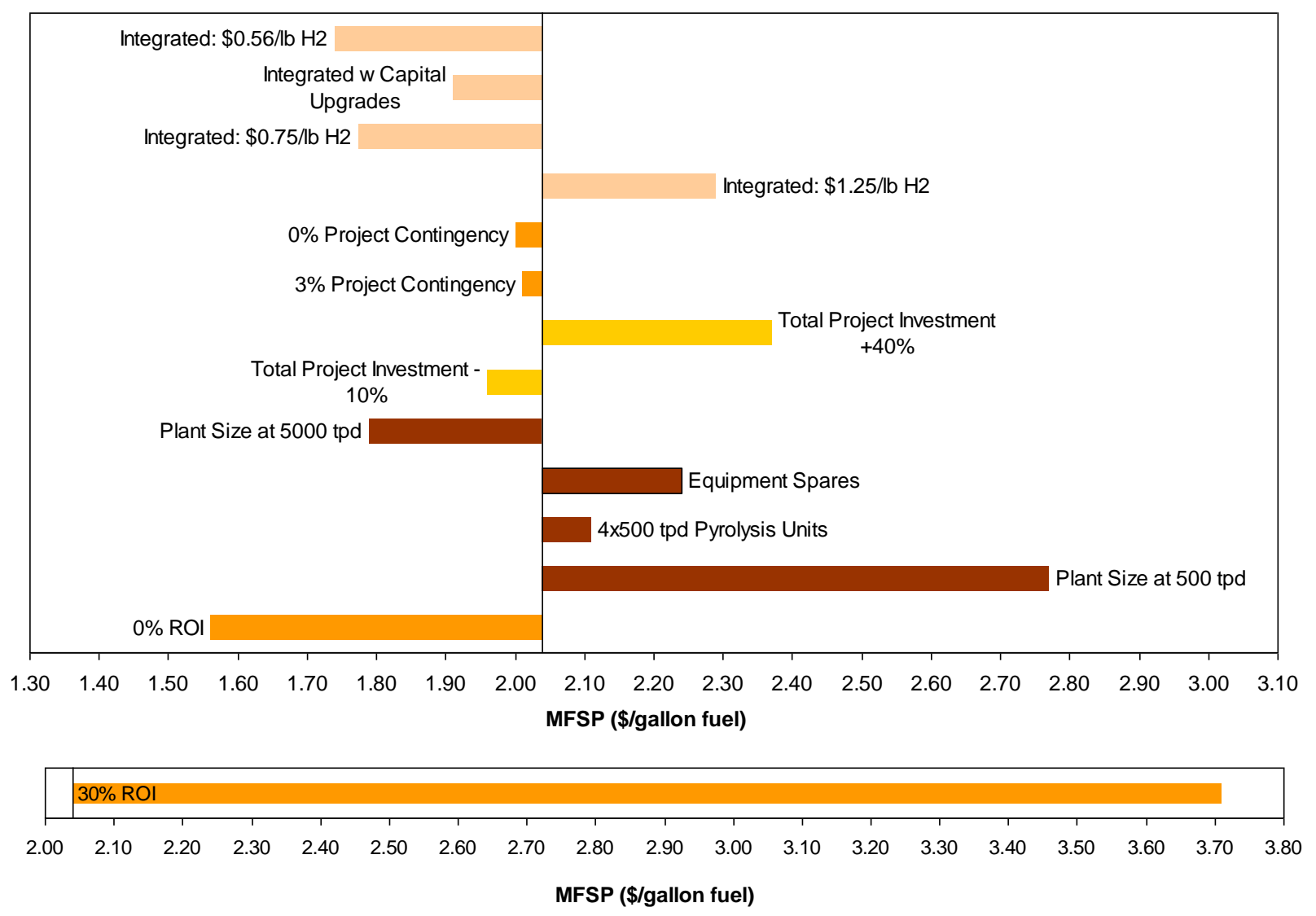

Figure 7.2. Financial/Market Sensitivities

The base case assumes a 10\% ROI. A 30\% return (shown on a separate scale to prevent making the other sensitivities illegible) nearly doubles the baseline estimated selling price. The $0 \%$ return represents the plant gate costs.

\subsection{Research Sensitivities}

The research sensitivities are shown in Figure 7.3. Feedstock cost, reactor space velocity, reactor pressure, and catalyst life all impact the minimum selling price for the standalone case. None of these costs alone make the process uneconomic. However, the potential combined effects, such as catalyst life and space velocity, are significant enough to warrant further research. Catalyst costs are important because there is little data on life and the appropriate catalyst composition. As a base case, this study assumes standard hydrotreating and hydrocracking catalysts.

The base case assumes that the two stage hydrotreaters described in Section 5.2 sufficiently deoxygenate the stable oil, and only the heavy tail end requires hydrocracking. If this is not sufficient, 
and the entire stable oil stream is sent to the hydrocracker, the size of the hydrocracker increases significantly. Hydrocracking the entire stable oil stream adds $\$ 0.10 /$ gal to price of the fuel.

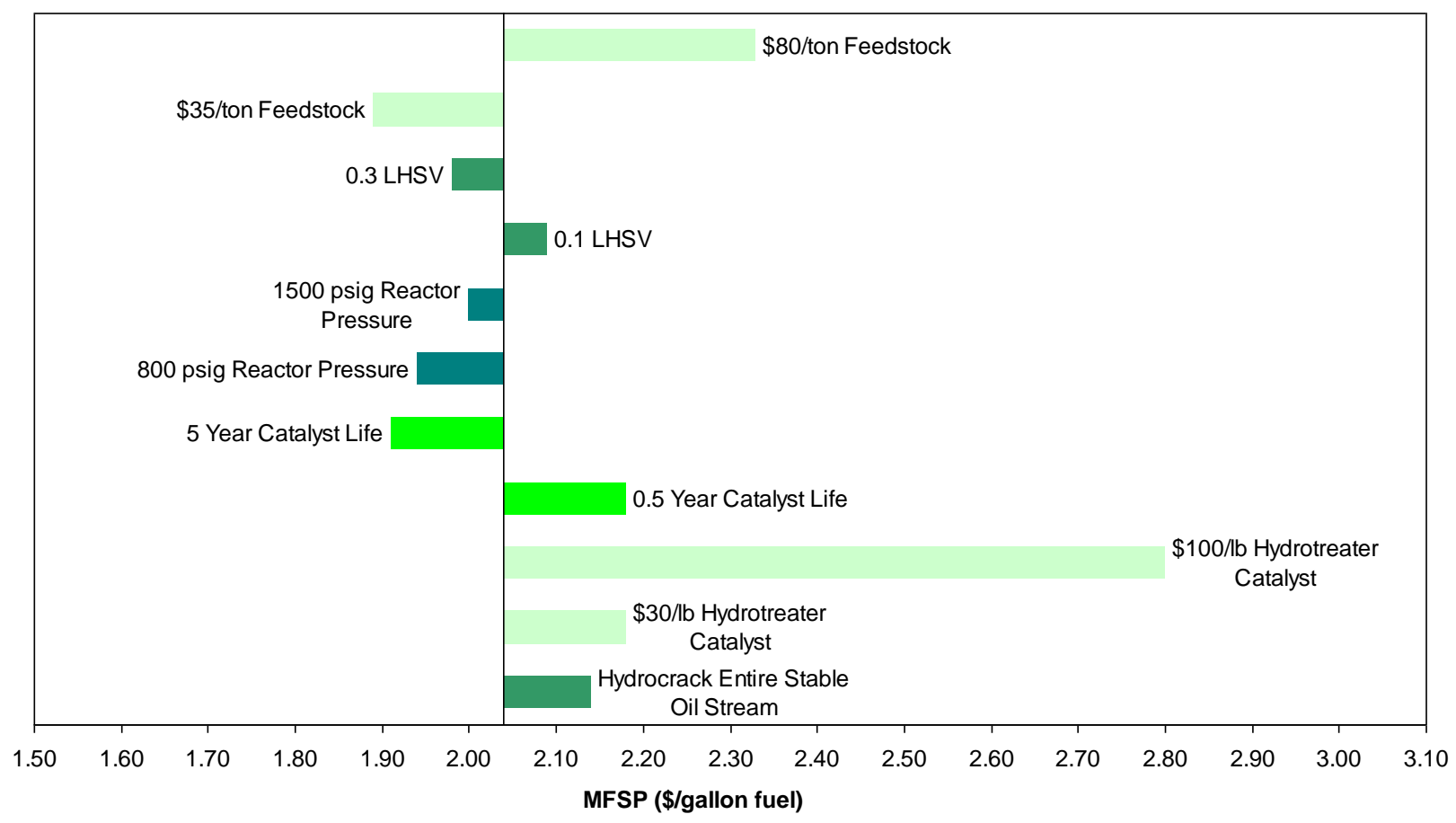

Figure 7.3. Research Sensitivities 


\subsection{Conclusions and Recommendations}

This analysis suggests that production of hydrocarbon motor fuels from biomass via the pyrolysis route is potentially economically attractive. The cost becomes even more favorable if the facility can be closely associated with an existing petroleum refinery to leverage that infrastructure. Both the standalone plant that combines fast pyrolysis with hydrotreating, upgrading and hydrocracking to fuels and the refinery-integrated plant fit with the existing infrastructure in terms of products and processing methods. Developing partnerships with industry suppliers and refiners is important for production development and product acceptance.

The pyrolysis pathway for producing hydrocarbon fuels is economically competitive with either the biological or thermochemical pathways for production of ethanol fuels. On an energy-equivalent basis, as shown in Table 7.1, the costs of either hydrocarbon or alcohol fuels are essentially the same when consistent analysis methodologies and underlying financial assumptions are used.

As indicated previously, other pyrolytic processes exist, and the economics of those processes may be different from the one analyzed here. This analysis suggests that cost-effective processing routes to hydrocarbon fuels exist, but does not attempt to compare this approach with others. If other pyrolytic processing routes have lower costs, the production of hydrocarbon fuels will be even more attractive.

The analysis describes a system with performance projected to be available in 2012. Further research and development is needed to understand the limitations of the process and where improvements can be made. The sensitivity analysis (Figure 7.3) suggests that the biggest impacts of technical improvements are in the area of catalysis as it relates to bio-oil upgrading. Catalyst lifetimes and performance are essential to the process and need additional development and testing. Pyrolytic processing of the biomass is a relatively small percentage of the overall cost, and changes to the pyrolysis process will have little direct impact on the fuel cost. However, research on pyrolytic processing that leads to a better quality bio-oil requiring less upgrading could also potentially reduce product costs.

The analysis (Figure 7.2) also shows the fuel costs are highly sensitive to plant size and ROI. The close coupling of the upgrading steps with a petroleum refinery helps leverage the economies of scale in the fuel production steps. The pyrolysis step to produce bio-oil is less sensitive to scale and can potentially be decoupled from the fuel upgrading step. This analysis uses figures for ROI that are consistent with previous biofuels analyses produced by DOE and allow comparison with other technology options. Industries attempting to build actual facilities may use different assumptions, and the costs for the resulting fuels would change accordingly.

To achieve the potential for producing hydrocarbon fuels from biomass, additional research and development are needed. A summary of needs includes the following:

- Understand the trade-off between the size of the pyrolysis oil plant and feedstock and transportation costs to a centralized upgrading facility.

- Incorporate the reductions in feed preprocessing (grinding and drying) by using a reactor ready feed.

- Understand pyrolysis reactor and upgrading reactor scale-up limitations if any.

- Improve the quality and consistency of bio-oil. 
- Determine detailed characterization of upgraded oil and products, for example:

- boiling point curves and densities

- compound types (\% aromatics, naphthenes, olefins, iso and normal) within the gasoline, diesel and heavy fraction ranges

- acid number.

- Conduct catalyst life studies for the pyrolysis oil upgrading catalysts.

- Develop better understanding of reactor limitations and opportunities by developing a predictive pyrolysis-oil production model and upgrading the reactor model to replace the stoichiometric models used in this study.

- Determine stable oil and product fuel specifications for oil refinery acceptance.

In addition, there are new initiatives for an advanced pyrolysis process for biomass, the details of which fall outside this base-case study. Incorporation of those new concepts into economic assessments of future cases for biomass pyrolysis should be the next stage of analysis. Advanced pyrolysis processes may include:

- new reactor system engineering involving improved heat transfer mechanisms

- pyrolysis including in-situ catalysis

- pyrolysis including in-situ chemical processing

- post pyrolysis processing to improve product bio-oil properties

- in-process separation systems to produce bio-oil fractions with useful properties

- post-process separations and subsequent treatment to produce improved products

- higher efficiency integrated systems with improved heat utilization. 


\subsection{References}

Aden A, M Ruth, K Ibsen, J Jechura, K Neeves, J Sheehan, B Wallace, L Montague, A Slayton, and J Lukas. 2002. Lignocellulosic Biomass to Ethanol Process Design and Economics Utilizing Co-Current Dilute Acid Prehydrolysis and Enzymatic Hydrolysis for Corn Stover. NREL/TP-510-32438, National Renewable Energy Laboratory, Golden, Colorado. http://www.nrel.gov/docs/fy02osti/32438.pdf

Beckman D, DC Elliott, B Gevert, C Hornell, B Kjellstrom, A Ostman, Y Solantausta, and V Tulnheimo. 1990. Techno-economic Assessment of Selected Biomass Liquefaction Processes. Research Report 697, VTT Technical Research Centre of Finland.

Bridgewater, T. 2007. Biomass Pyrolysis. T34:2007:01, International Energy Agency Bioenergy, Rotorua, New Zealand. http://www.ieabioenergy.com/MediaItem.aspx?id=5416

Bridgewater AV, AJ Toft, and JG Brammer. 2002. "A Techno-economic Comparison of Power Production by Biomass Fast Pyrolysis with Gasification and Combustion”. Renewable \& Sustainable Energy Reviews 6:181-248.

BTG website: http://www.btgworld.com. Accessed 1/2009.

Couper JR, WR Pennery, JR Fair, and SM Walas. 2005. Chemical Process Equipment Selection and Design. $2^{\text {nd }}$ ed. Elsevier, Amsterdam.

Diebold JP. 2000. A Review of the Chemical and Physical Mechanisms of the Storage Stability of Fast Pyrolysis Bio-Oils. NREL/SR-570-27613, Golden, Colorado.

http://www.nrel.gov/docs/fy00osti/27613.pdf

U.S. Department of Energy. 2008. Biomass Multi-Year Program Plan. Office of the Biomass Program, Energy Efficiency and Renewable Energy, U.S. Department of Energy, Washington D.C. http://www1.eere.energy.gov/biomass/pdfs/biomass_program mypp.pdf

Dynamotive. 2007. "Dynamotive, The Evolution of Energy." Accessed 2/5/2008 at http://www.dynamotive.com/en/news/releases/2007/december/071205.html

Energy Information Agency. Industrial Electricity and Natural Gas Prices Jan-Nov 2007 average. Retail Gasoline and Diesel Prices Jan-Sept. 2007. Available at http://www.eia.doe.gov/

Ensyn website 2009. http://www.ensyn.com/about.htm

Elliott, DC. 2007. "Historical Developments in Hydroprocessing Bio-oil.” Energy \& Fuels 21:1792-1815.

Freel B and R Graham. 1995. "Method and Apparatus for a Circulating Bed Transport Fast Pyrolysis Reactor System.” US Patent 5,792,340. Ensyn Technologies Inc.

Gulf Publishing Co. 2006. Hydrocarbon Processing; Refining Processes 2006. Gulf Publishing Co., Houston, Texas.

Holmgren J, C Gosling, R Mariangeli, T Marker, G Rafaci, and C Perego. 2007."New Developments in Renewable Fuels Offer More Choices." Hydrocarbon Processing 86:59-72. 
Johnson WL, GH Yavari, and D St A G Radelin. 2006. “Apparatus for Separating Fouling Contaminants from Non-Condensable Gases at the End of a Pyrolysis/Thermolysis of Biomass Process." US Patent 7,004,999 B2. Dynamotive Energy Systems.

Marker T, J Petri, T Kalnes, M McCall, D Mackowiak, B Jerosky, B Regan, L Nemeth, M Krawczyk, S Czernik, D Elliot, and D Shonnard. 2005. "Opportunities for Biorenewables in Oil Refineries." UOP, Des Plaines, Illinois. http://www.osti.gov/energycitations/product.biblio.jsp?osti id=861458

Meyers RA. 2004. Handbook of Petroleum Refining Processes. $3^{\text {rd }}$ ed. McGraw-Hill, New York.

Mohan D, C Pittman, and P Steele. 2006. "Pyrolysis of Wood/Biomass for Bio-oil: A Critical Review." Energy \& Fuels 20:848-889.

Oasmaa A and E Kuoppala. 2003. "Fast Pyrolysis of Forestry Residue. 3. Stability of Liquid Fuel." Energy \& Fuels 17:1075-1084.

Parkash, S. 2003. "Hydrocracking Processes." Chapter 3 in Refining Processes Handbook. Gulf Professional Publishing/Elsevier, Boston/Amsterdam.

Perry RH, DW Green, and JO Maloney. 1984. Perry's Chemical Engineers' Handbook. $6^{\text {th }}$ ed. McGrawHill, New York.

Peters MS, KD Timmerhaus, and RE West. 2003. Plant Design and Economics for Chemical Engineers. $5^{\text {th }}$ ed, McGraw-Hill, New York.

Phillips S, A Aden, and J Jechura, D Dayton, and T Eggman 2007. Thermochemical Ethanol via Indirect Gasification and Mixed Alcohol Synthesis of Lignocellulosic Biomass. NREL/TP-510-41168. National Renewable Energy Laboratory, Golden, Colorado. http://www.nrel.gov/docs/fy07osti/41168.pdf

Phyllis Database for Biomass and Waste. "Hybrid Poplar." Version 4.13. Energy Research Center of the Netherlands. http://www.ecn.nl/phyllis

Ringer M, V Putsche, and J Scahill. 2006. Large-Scale Pyrolysis Oil Production: A Technology Assessment and Economic Analysis. NREL/TP-510-37779. National Renewable Energy Laboratory, Golden, Colorado.

Solantausta Y. 2003. Techno-Economic Assessment, the Finnish Case Study. COMBIO Project NNE5CT-00604, VTT Technical Research Centre of Finland, http://www.combio-project.com/economics.htm

Solantuasta Y. 2006. "Co-Processing of Upgraded Bio-Liquids in Standard Refinery Units - BIOCOUP." European Conference on Biorefinery Research Proceedings. http://ec.europa.eu/research/energy/gp/gp events/biorefinery/article 3764 en.htm

Spath P, A Aden, T Eggeman, M Ringer, B Wallace, and J Jechura. 2005. Biomass to Hydrogen Production Detailed Design and Economics Utilizing the Battelle Columbus Laboratory IndirectlyHeated Gasifier. NREL/TP-510-37408, National Renewable Energy Laboratory, Golden, Colorado. http://www.nrel.gov/docs/fy05osti/37408.pdf

SRI International. 2007. "Hydrogen Production from Natural Gas.” PEP Yearbook International, Vol 1E, SRI International, Menlo Park, California. 
White House Office of Communications. 2007. Twenty in Ten: Strengthening America's Energy Security. White House Office of Communications, Washington D.C. Available at http://www.energy.gov/media/20in10FactSheet.pdf 
Appendix A

\section{Design Case - Stand-Alone Heat and Material Balance}




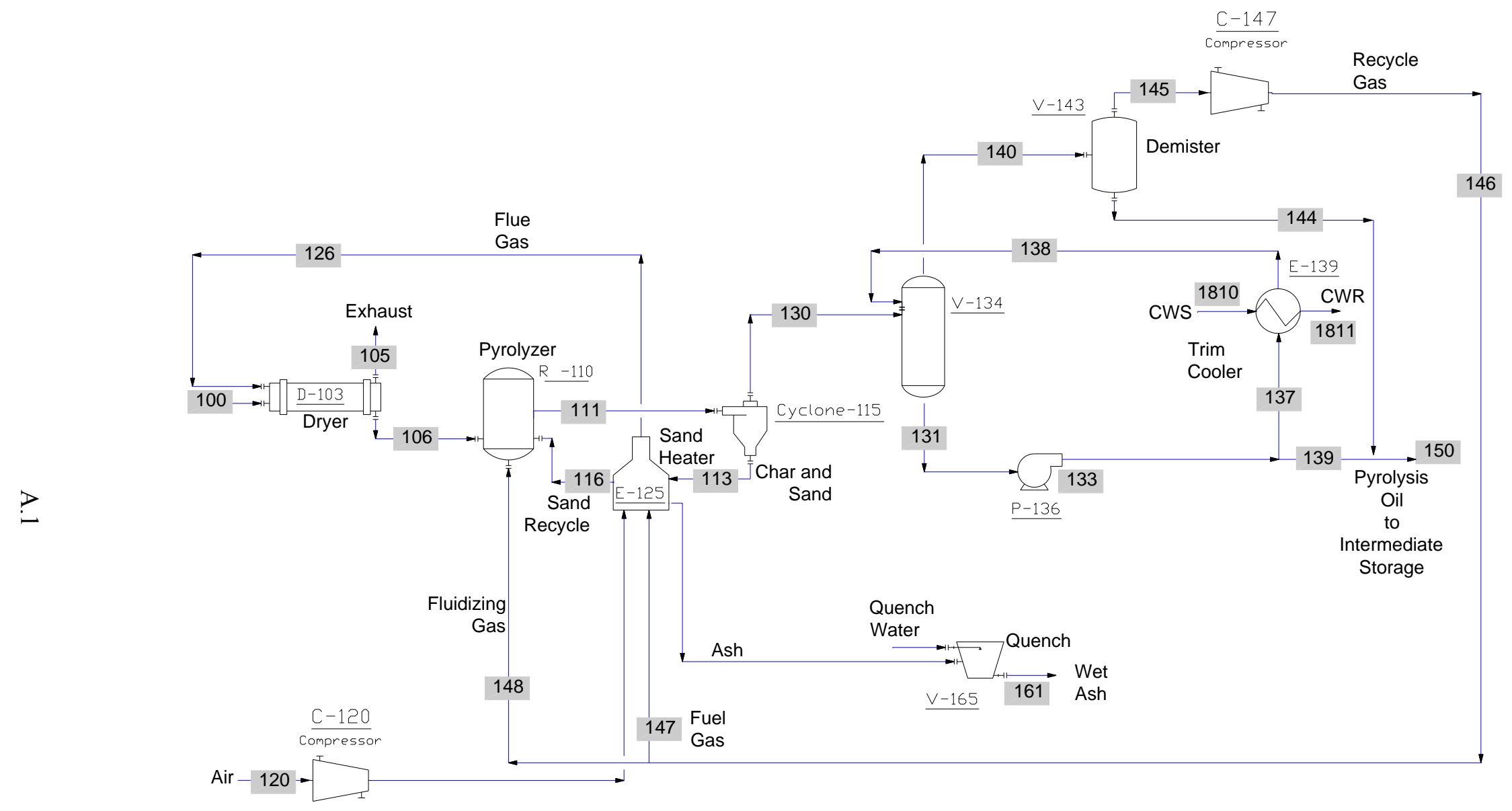

Figure A.1. Flow Diagram for Pyrolysis Unit 
Table A.1. Pyrolysis Unit Heat and Material Balance

\begin{tabular}{|c|c|c|c|c|c|c|c|c|c|c|c|}
\hline Stream No. & 100 & 105 & 106 & 111 & 113 & 116 & 120 & 126 & 130 & 131 & 133 \\
\hline Temp C & 20 & 176.587 & 66 & 499.421 & 499.421 & 592 & 15.5555 & 1211.84 & 499.421 & 43.7381 & 43.746 \\
\hline Pres psig & 3 & 3 & 3 & 1 & 1 & 1 & 0.3041 & 3 & 1 & 1 & 10 \\
\hline Enth MMBtu/h & -1743 & -1324.9 & -575.9 & -6192.3 & -5449.1 & -5322.2 & -1.4752 & -157.77 & -743.17 & -96574 & -96573 \\
\hline Vapor mass fraction & 0 & 1 & 0 & 1 & 1 & 0 & 1 & 1 & 1 & 0 & 4.17E-05 \\
\hline Total lb/h & 367436 & 560708 & 197546 & 3135535 & 2779270 & 2755767 & 350000 & 390817 & 356265 & $2.7 \mathrm{E}+07$ & 2.7E+07 \\
\hline \multicolumn{12}{|l|}{ Flowrates in lb/h } \\
\hline Oxygen & 0 & 24433.8 & 0 & 3873.85 & 3873.85 & 0 & 81520.1 & 24435 & 0 & 0 & 0 \\
\hline Nitrogen & 0 & 269595 & 0 & 10673.8 & 0 & 0 & 268480 & 269595 & 10673.8 & 80.5111 & 80.496 \\
\hline Water & 183718 & 180076 & 13828.2 & 32280.7 & 0 & 0 & 0 & 10186 & 32280.7 & 4480534 & 4480506 \\
\hline Hybrid Poplar & 183718 & 0 & 183718 & 0.0041 & 0.0041 & 0 & 0 & 0 & 0 & 0 & 0 \\
\hline Hydrogen & 0 & 2.0727 & 0 & 1403.29 & 963.918 & 0 & 0 & 2.0729 & 439.369 & 1.3593 & 1.359 \\
\hline Carbon & 0 & 0 & 0 & 15065.9 & 15065.9 & 0 & 0 & 0 & 0 & 0 & 0 \\
\hline Carbon Monoxide & 0 & 513.829 & 0 & 175437 & 0 & 0 & 0 & 513.888 & 175437 & 1272.26 & 1272.03 \\
\hline Carbon Dioxide & 0 & 86088.1 & 0 & 9738.7 & 0 & 0 & 0 & 86085.5 & 9738.7 & 2331.92 & 2331.05 \\
\hline Methane & 0 & 0.0002 & 0 & 876.195 & 0 & 0 & 0 & 0.0002 & 876.195 & 27.2094 & 27.2046 \\
\hline Ethylene & 0 & 0.0004 & 0 & 3488.06 & 0 & 0 & 0 & 0.0004 & 3488.06 & 475.291 & 475.223 \\
\hline Ethane & 0 & 0 & 0 & 0 & 0 & 0 & 0 & 0 & 0 & 0 & 0 \\
\hline Propylene & 0 & 0.0006 & 0 & 3629.54 & 0 & 0 & 0 & 0.0006 & 3629.54 & 2174.05 & 2173.91 \\
\hline Propane & 0 & 0 & 0 & 0 & 0 & 0 & 0 & 0 & 0 & 0 & 0 \\
\hline I-Butane & 0 & 0 & 0 & 0 & 0 & 0 & 0 & 0 & 0 & 0 & 0 \\
\hline Ammonia & 0 & 0.0003 & 0 & 285.508 & 0 & 0 & 0 & 0.0003 & 285.508 & 468.22 & 468.193 \\
\hline Pyro-lignin & 0 & 0 & 0 & 64485 & 0 & 0 & 0 & 0 & 64485 & $1.2 \mathrm{E}+07$ & $1.2 \mathrm{E}+07$ \\
\hline Cellobiose & 0 & 0 & 0 & 22689.1 & 0 & 0 & 0 & 0 & 22689.1 & 4500798 & 4501477 \\
\hline Levoglucosan & 0 & 0 & 0 & 5970.83 & 0 & 0 & 0 & 0 & 5970.83 & 1087896 & 1087571 \\
\hline Furfural & 0 & 0 & 0 & 11941.7 & 0 & 0 & 0 & 0 & 11941.7 & 2078346 & 2078007 \\
\hline HydroxyAcetone & 0 & 0 & 0 & 5970.83 & 0 & 0 & 0 & 0 & 5970.83 & 1098279 & 1098360 \\
\hline Acetic Acid & 0 & 0 & 0 & 8359.16 & 0 & 0 & 0 & 0 & 8359.16 & 1192790 & 1192921 \\
\hline Formaldehyde & 0 & 0 & 0 & 0 & 0 & 0 & 0 & 0 & 0 & 0 & 0 \\
\hline 2-5-Xylenol & 0 & 0 & 0 & 0 & 0 & 0 & 0 & 0 & 0 & 0 & 0 \\
\hline N-Heptane & 0 & 0 & 0 & 0 & 0 & 0 & 0 & 0 & 0 & 0 & 0 \\
\hline 1-ts-35-3С1СycС6 & 0 & 0 & 0 & 0 & 0 & 0 & 0 & 0 & 0 & 0 & 0 \\
\hline 3-3-5-TriMth-C7 & 0 & 0 & 0 & 0 & 0 & 0 & 0 & 0 & 0 & 0 & 0 \\
\hline N-PropylCyc-C6 & 0 & 0 & 0 & 0 & 0 & 0 & 0 & 0 & 0 & 0 & 0 \\
\hline 1-2-3-Mesitylene & 0 & 0 & 0 & 0 & 0 & 0 & 0 & 0 & 0 & 0 & 0 \\
\hline N-ButylCycHexane & 0 & 0 & 0 & 0 & 0 & 0 & 0 & 0 & 0 & 0 & 0 \\
\hline 1-2-DiC1-3C2-Bz & 0 & 0 & 0 & 0 & 0 & 0 & 0 & 0 & 0 & 0 & 0 \\
\hline Cis-Decalin & 0 & 0 & 0 & 0 & 0 & 0 & 0 & 0 & 0 & 0 & 0 \\
\hline Dimethyl-C11 & 0 & 0 & 0 & 0 & 0 & 0 & 0 & 0 & 0 & 0 & 0 \\
\hline 1-2-4-triethylbe & 0 & 0 & 0 & 0 & 0 & 0 & 0 & 0 & 0 & 0 & 0 \\
\hline 1-1-Bicyclohexyl & 0 & 0 & 0 & 0 & 0 & 0 & 0 & 0 & 0 & 0 & 0 \\
\hline Diphenyl & 0 & 0 & 0 & 0 & 0 & 0 & 0 & 0 & 0 & 0 & 0 \\
\hline diamantane & 0 & 0 & 0 & 0 & 0 & 0 & 0 & 0 & 0 & 0 & 0 \\
\hline Phenanthrene & 0 & 0 & 0 & 0 & 0 & 0 & 0 & 0 & 0 & 0 & 0 \\
\hline N-C15-CycloC5 & 0 & 0 & 0 & 0 & 0 & 0 & 0 & 0 & 0 & 0 & 0 \\
\hline Hexatriacontane & 0 & 0 & 0 & 0 & 0 & 0 & 0 & 0 & 0 & 0 & 0 \\
\hline $\mathrm{Ca}$ & 0 & 0 & 0 & 3496.15 & 3496.15 & 0 & 0 & 0 & 0 & 0 & 0 \\
\hline Sulphur & 0 & 0 & 0 & 36.0271 & 36.0271 & 0 & 0 & 0 & 0 & 0 & 0 \\
\hline Calcium Chloride & 0 & 0 & 0 & 67.057 & 67.057 & 0 & 0 & 0 & 0 & 0 & 0 \\
\hline Sand & 0 & 0 & 0 & 2755767 & 2755767 & 2755767 & 0 & 0 & 0 & 0 & 0 \\
\hline
\end{tabular}


Table A.1. (contd)

\begin{tabular}{|c|c|c|c|c|c|c|c|c|c|c|c|}
\hline Stream No. & 137 & 138 & 139 & 140 & 144 & 145 & 146 & 147 & 148 & 150 & 161 \\
\hline Temp C & 43.746 & 37.7778 & 43.746 & 43.7381 & 43.7381 & 43.7381 & 91.8145 & 91.8145 & 91.8145 & 43.7199 & 105.294 \\
\hline Pres psig & 10 & 5 & 10 & 1 & 1 & 1 & 8 & 8 & 8 & 1 & 3 \\
\hline Enth MMBtu/h & -96072 & -96222 & -501.34 & -391.99 & -69.9 & -332.32 & -327.7 & -33.491 & -294.2 & -571.24 & -37.313 \\
\hline Vapor mass fraction & 4.17E-05 & $4.70 \mathrm{E}-05$ & 4.17E-05 & 1 & 0 & 1 & 1 & 1 & 1 & $5.38 \mathrm{E}-05$ & 0.50092 \\
\hline Total lb/h & $3 \mathrm{E}+07$ & $2.7 \mathrm{E}+07$ & 139274 & 216984 & 12363 & 204621 & 204621 & 20912.8 & 183708 & 151637 & 9599.24 \\
\hline \multicolumn{12}{|l|}{ Flowrates in lb/h } \\
\hline Oxygen & 0 & 0 & 0 & 0 & 0 & 0 & 0 & 0 & 0 & 0 & 0 \\
\hline Nitrogen & 80.078 & 80.0782 & 0.4179 & 10673.4 & 0 & 10673.4 & 10673.4 & 1090.85 & 9582.52 & 0.4179 & 0 \\
\hline Water & $4 \mathrm{E}+06$ & 4457246 & 23259.8 & 8992.01 & 8902.09 & 89.9201 & 89.9201 & 9.1901 & 80.73 & 32161.8 & 6000 \\
\hline Hybrid Poplar & 0 & 0 & 0 & 0 & 0 & 0 & 0 & 0 & 0 & 0 & 0 \\
\hline Hydrogen & 1.352 & 1.352 & 0.0071 & 439.362 & 0 & 439.362 & 439.362 & 44.904 & 394.458 & 0.0071 & 0 \\
\hline Carbon & 0 & 0 & 0 & 0 & 0 & 0 & 0 & 0 & 0 & 0 & 0.0002 \\
\hline Carbon Monoxide & 1265.4 & 1265.43 & 6.6035 & 175430 & 0 & 175430 & 175430 & 17929.4 & 157500 & 6.6035 & 0 \\
\hline Carbon Dioxide & 2319 & 2318.95 & 12.1013 & 9725.74 & 0 & 9725.74 & 9725.74 & 993.998 & 8731.74 & 12.1012 & 0 \\
\hline Methane & 27.063 & 27.0633 & 0.1412 & 876.049 & 0 & 876.049 & 876.049 & 89.5347 & 786.514 & 0.1412 & 0 \\
\hline Ethylene & 472.76 & 472.756 & 2.467 & 3485.52 & 0 & 3485.52 & 3485.52 & 356.23 & 3129.29 & 2.467 & 0 \\
\hline Ethane & 0 & 0 & 0 & 0 & 0 & 0 & 0 & 0 & 0 & 0 & 0 \\
\hline Propylene & 2162.6 & 2162.62 & 11.2855 & 3618.11 & 0 & 3618.11 & 3618.11 & 369.781 & 3248.33 & 11.2855 & 0 \\
\hline Propane & 0 & 0 & 0 & 0 & 0 & 0 & 0 & 0 & 0 & 0 & 0 \\
\hline I-Butane & 0 & 0 & 0 & 0 & 0 & 0 & 0 & 0 & 0 & 0 & 0 \\
\hline Ammonia & 465.76 & 465.763 & 2.4305 & 283.051 & 0 & 283.051 & 283.051 & 28.9286 & 254.123 & 2.4305 & 0 \\
\hline Pyro-lignin & $1 \mathrm{E}+07$ & $1.2 \mathrm{E}+07$ & 64281.4 & 0.044 & 0.044 & 0 & 0 & 0 & 0 & 64281.4 & 0 \\
\hline Cellobiose & $4 \mathrm{E}+06$ & 4478109 & 23368.6 & 0.0129 & 0.0129 & 0 & 0 & 0 & 0 & 23368.7 & 0 \\
\hline Levoglucosan & $1 \mathrm{E}+06$ & 1081925 & 5645.94 & 0.0011 & 0.0011 & 0 & 0 & 0 & 0 & 5645.94 & 0 \\
\hline Furfural & $2 \mathrm{E}+06$ & 2067219 & 10787.6 & 814.207 & 814.207 & 0 & 0 & 0 & 0 & 11601.8 & 0 \\
\hline HydroxyAcetone & $1 \mathrm{E}+06$ & 1092658 & 5701.95 & 349.864 & 349.864 & 0 & 0 & 0 & 0 & 6051.81 & 0 \\
\hline Acetic Acid & $1 \mathrm{E}+06$ & 1186728 & 6192.84 & 2296.82 & 2296.82 & 0 & 0 & 0 & 0 & 8489.66 & 0 \\
\hline Formaldehyde & 0 & 0 & 0 & 0 & 0 & 0 & 0 & 0 & 0 & 0 & 0 \\
\hline 2-5-Xylenol & 0 & 0 & 0 & 0 & 0 & 0 & 0 & 0 & 0 & 0 & 0 \\
\hline N-Heptane & 0 & 0 & 0 & 0 & 0 & 0 & 0 & 0 & 0 & 0 & 0 \\
\hline 1-ts-35-3C1СycС6 & 0 & 0 & 0 & 0 & 0 & 0 & 0 & 0 & 0 & 0 & 0 \\
\hline 3-3-5-TriMth-C7 & 0 & 0 & 0 & 0 & 0 & 0 & 0 & 0 & 0 & 0 & 0 \\
\hline N-PropylCyc-C6 & 0 & 0 & 0 & 0 & 0 & 0 & 0 & 0 & 0 & 0 & 0 \\
\hline 1-2-3-Mesitylene & 0 & 0 & 0 & 0 & 0 & 0 & 0 & 0 & 0 & 0 & 0 \\
\hline N-ButylCycHexane & 0 & 0 & 0 & 0 & 0 & 0 & 0 & 0 & 0 & 0 & 0 \\
\hline 1-2-DiC1-3C2-Bz & 0 & 0 & 0 & 0 & 0 & 0 & 0 & 0 & 0 & 0 & 0 \\
\hline Cis-Decalin & 0 & 0 & 0 & 0 & 0 & 0 & 0 & 0 & 0 & 0 & 0 \\
\hline Dimethyl-C11 & 0 & 0 & 0 & 0 & 0 & 0 & 0 & 0 & 0 & 0 & 0 \\
\hline 1-2-4-triethylbe & 0 & 0 & 0 & 0 & 0 & 0 & 0 & 0 & 0 & 0 & 0 \\
\hline 1-1-Bicyclohexyl & 0 & 0 & 0 & 0 & 0 & 0 & 0 & 0 & 0 & 0 & 0 \\
\hline Diphenyl & 0 & 0 & 0 & 0 & 0 & 0 & 0 & 0 & 0 & 0 & 0 \\
\hline diamantane & 0 & 0 & 0 & 0 & 0 & 0 & 0 & 0 & 0 & 0 & 0 \\
\hline Phenanthrene & 0 & 0 & 0 & 0 & 0 & 0 & 0 & 0 & 0 & 0 & 0 \\
\hline N-C15-CycloC5 & 0 & 0 & 0 & 0 & 0 & 0 & 0 & 0 & 0 & 0 & 0 \\
\hline Hexatriacontane & 0 & 0 & 0 & 0 & 0 & 0 & 0 & 0 & 0 & 0 & 0 \\
\hline $\mathrm{Ca}$ & 0 & 0 & 0 & 0 & 0 & 0 & 0 & 0 & 0 & 0 & 3496.16 \\
\hline Sulphur & 0 & 0 & 0 & 0 & 0 & 0 & 0 & 0 & 0 & 0 & 36.0271 \\
\hline Calcium Chloride & 0 & 0 & 0 & 0 & 0 & 0 & 0 & 0 & 0 & 0 & 67.057 \\
\hline Sand & 0 & 0 & 0 & 0 & 0 & 0 & 0 & 0 & 0 & 0 & 0 \\
\hline
\end{tabular}


Table A.1. (contd)

\begin{tabular}{|c|c|c|}
\hline Stream No. & 1810 & 1811 \\
\hline Temp C & 32.2222 & 40.5555 \\
\hline Pres psig & 50 & 45 \\
\hline Enth MMBtu/h & -68430 & -68279 \\
\hline Vapor mass fraction & 0 & 0 \\
\hline Total lb/h & 10044315 & 10044310 \\
\hline \multicolumn{3}{|l|}{ Flowrates in lb/h } \\
\hline Oxygen & 0 & 0 \\
\hline Nitrogen & 0 & 0 \\
\hline Water & 10044315 & 10044310 \\
\hline Hybrid Poplar & 0 & 0 \\
\hline Hydrogen & 0 & 0 \\
\hline Carbon & 0 & 0 \\
\hline Carbon Monoxide & 0 & 0 \\
\hline Carbon Dioxide & 0 & 0 \\
\hline Methane & 0 & 0 \\
\hline Ethylene & 0 & 0 \\
\hline Ethane & 0 & 0 \\
\hline Propylene & 0 & 0 \\
\hline Propane & 0 & 0 \\
\hline I-Butane & 0 & 0 \\
\hline Ammonia & 0 & 0 \\
\hline Pyro-lignin & 0 & 0 \\
\hline Cellobiose & 0 & 0 \\
\hline Levoglucosan & 0 & 0 \\
\hline Furfural & 0 & 0 \\
\hline HydroxyAcetone & 0 & 0 \\
\hline Acetic Acid & 0 & 0 \\
\hline Formaldehyde & 0 & 0 \\
\hline 2-5-Xylenol & 0 & 0 \\
\hline N-Heptane & 0 & 0 \\
\hline 1-ts-35-3C1СycC6 & 0 & 0 \\
\hline 3-3-5-TriMth-C7 & 0 & 0 \\
\hline N-PropylCyc-C6 & 0 & 0 \\
\hline 1-2-3-Mesitylene & 0 & 0 \\
\hline N-ButylCycHexane & 0 & 0 \\
\hline 1-2-DiC1-3C2-Bz & 0 & 0 \\
\hline Cis-Decalin & 0 & 0 \\
\hline Dimethyl-C11 & 0 & 0 \\
\hline 1-2-4-triethylbe & 0 & 0 \\
\hline 1-1-Bicyclohexyl & 0 & 0 \\
\hline Diphenyl & 0 & 0 \\
\hline diamantane & 0 & 0 \\
\hline Phenanthrene & 0 & 0 \\
\hline N-C15-CycloC5 & 0 & 0 \\
\hline Hexatriacontane & 0 & 0 \\
\hline $\mathrm{Ca}$ & 0 & 0 \\
\hline Sulphur & 0 & 0 \\
\hline Calcium Chloride & 0 & 0 \\
\hline Sand & 0 & 0 \\
\hline
\end{tabular}




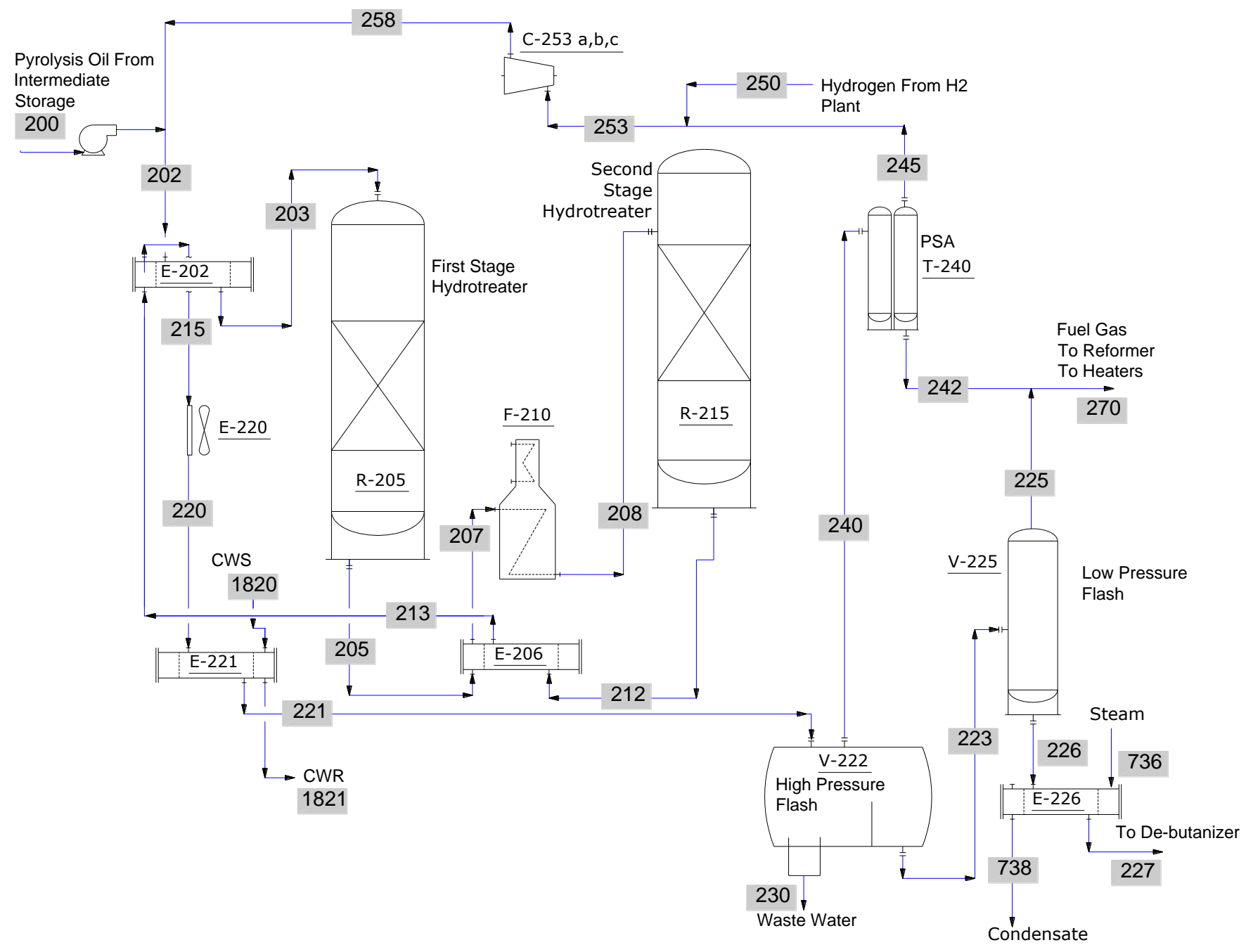

Figure A.2. Flow Diagram for Pyrolysis Oil Stabilization 
Table A.2. Pyrolysis Oil Hydrotreating Heat and Material Balance

\begin{tabular}{|c|c|c|c|c|c|c|c|c|c|c|c|}
\hline Stream No. & 200 & 202 & 203 & 205 & 207 & 208 & 212 & 213 & 215 & 220 & 221 \\
\hline Temp F & 110.6798 & 174.8342 & 430 & 465.5045 & 470 & 700 & 484.8971 & 481.4931 & 319.3935 & 150 & 110 \\
\hline Pres psig & 1 & 2500 & 2495 & 2495 & 2490 & 2475 & 2475 & 2470 & 710.3041 & 705.3041 & 700.3041 \\
\hline Enth MMBtu/h & -579.38 & -572.13 & -533.75 & -533.75 & -532.53 & -493.17 & -493.17 & -494.39 & -532.77 & -560.91 & -566.01 \\
\hline Vapor mass fraction & 0 & 0.062243 & 0.15953 & 0.24881 & 0.25969 & 0.52647 & 0.6898 & 0.67505 & 0.22969 & 0.12881 & 0.12332 \\
\hline Total lb/h & 151607.6 & 161371 & 161371 & 161371 & 161371 & 161371 & 161371 & 161374.8 & 161374.8 & 161374.8 & 161374.8 \\
\hline \multicolumn{12}{|l|}{ Flowrates in lb/h } \\
\hline Water & 32161.65 & 32161.64 & 32161.64 & 44375.22 & 44375.22 & 44375.22 & 71936 & 71936 & 71936 & 71936 & 71936 \\
\hline Hydrogen & 0 & 9763.431 & 9763.431 & 8474.411 & 8474.411 & 8474.411 & 3839.811 & 3843.556 & 3843.557 & 3843.557 & 3843.557 \\
\hline Carbon Dioxide & 0 & 0 & 0 & 1000 & 1000 & 1000 & 9000.002 & 9000.002 & 9000.003 & 9000.003 & 9000.004 \\
\hline Methane & 0 & 0 & 0 & 50 & 50 & 50 & 3350 & 3350 & 3350 & 3350 & 3350 \\
\hline Ethane & 0 & 0 & 0 & 6.9 & 6.9 & 6.9 & 2006.899 & 2006.9 & 2006.9 & 2006.9 & 2006.9 \\
\hline Propane & 0 & 0 & 0 & 5.1 & 5.1 & 5.1 & 1705.1 & 1705.101 & 1705.101 & 1705.101 & 1705.101 \\
\hline I-Butane & 0 & 0 & 0 & 4.4 & 4.4 & 4.4 & 1504.4 & 1504.4 & 1504.4 & 1504.4 & 1504.4 \\
\hline Pyro-lignin & 64305.6 & 64305.58 & 64305.58 & 54819.78 & 54819.78 & 54819.79 & 0 & 0 & 0 & 0 & 0 \\
\hline Cellobiose & 23313.63 & 23313.62 & 23313.62 & 13988.17 & 13988.17 & 13988.17 & 0.0037 & 0.0051 & 0.0051 & 0.0051 & 0.0051 \\
\hline Levoglucosan & 5674.065 & 5674.063 & 5674.063 & 2724.021 & 2724.021 & 2724.021 & 0.001 & 0.0014 & 0.0014 & 0.0014 & 0.0014 \\
\hline Furfural & 11633.4 & 11633.4 & 11633.4 & 0 & 0 & 0 & 0 & 0 & 0 & 0 & 0 \\
\hline HydroxyAcetone & 6044.922 & 6044.922 & 6044.922 & 4835.938 & 4835.938 & 4835.938 & 0 & 0 & 0 & 0 & 0 \\
\hline Acetic Acid & 8474.371 & 8474.367 & 8474.367 & 5084.619 & 5084.619 & 5084.619 & 0 & 0 & 0 & 0 & 0 \\
\hline 2-5-Xylenol & 0 & 0 & 0 & 26002.45 & 26002.45 & 26002.45 & 8000.004 & 8000.002 & 8000.001 & 8000.001 & 8000.001 \\
\hline $\mathrm{N}$-Heptane & 0 & 0 & 0 & 0 & 0 & 0 & 3275.653 & 3275.653 & 3275.654 & 3275.654 & 3275.655 \\
\hline 1-ts-35-3С1СycС6 & 0 & 0 & 0 & 0 & 0 & 0 & 4892.768 & 4892.769 & 4892.768 & 4892.768 & 4892.769 \\
\hline 3-3-5-TriMth-C7 & 0 & 0 & 0 & 0 & 0 & 0 & 1994.707 & 1994.707 & 1994.707 & 1994.707 & 1994.707 \\
\hline N-PropylCyc-C6 & 0 & 0 & 0 & 0 & 0 & 0 & 4892.767 & 4892.769 & 4892.769 & 4892.769 & 4892.77 \\
\hline 1-2-3-Mesitylene & 0 & 0 & 0 & 0 & 0 & 0 & 642.0663 & 642.0664 & 642.0664 & 642.0664 & 642.0665 \\
\hline N-ButylCycHexane & 0 & 0 & 0 & 0 & 0 & 0 & 234.2028 & 234.2029 & 234.2029 & 234.2029 & 234.2029 \\
\hline 1-2-DiC1-3C2-Bz & 0 & 0 & 0 & 0 & 0 & 0 & 1593.217 & 1593.217 & 1593.217 & 1593.217 & 1593.217 \\
\hline Cis-Decalin & 0 & 0 & 0 & 0 & 0 & 0 & 3186.433 & 3186.433 & 3186.433 & 3186.433 & 3186.433 \\
\hline Dimethyl-C11 & 0 & 0 & 0 & 0 & 0 & 0 & 8635.319 & 8635.321 & 8635.321 & 8635.321 & 8635.322 \\
\hline 1-2-4-triethylbe & 0 & 0 & 0 & 0 & 0 & 0 & 3186.432 & 3186.434 & 3186.434 & 3186.434 & 3186.433 \\
\hline 1-1-Bicyclohexyl & 0 & 0 & 0 & 0 & 0 & 0 & 238.9825 & 238.9825 & 238.9825 & 238.9825 & 238.9825 \\
\hline Diphenyl & 0 & 0 & 0 & 0 & 0 & 0 & 4383.289 & 4383.289 & 4383.289 & 4383.289 & 4383.289 \\
\hline diamantane & 0 & 0 & 0 & 0 & 0 & 0 & 8635.319 & 8635.321 & 8635.321 & 8635.321 & 8635.322 \\
\hline Phenanthrene & 0 & 0 & 0 & 0 & 0 & 0 & 6087.9 & 6087.901 & 6087.901 & 6087.901 & 6087.902 \\
\hline N-C15-CycloC5 & 0 & 0 & 0 & 0 & 0 & 0 & 291.442 & 291.4421 & 291.442 & 291.442 & 291.442 \\
\hline Hexatriacontane & 0 & 0 & 0 & 0 & 0 & 0 & 0 & 0 & 0 & 0 & 0 \\
\hline Chrysene & 0 & 0 & 0 & 0 & 0 & 0 & 6120.283 & 6120.284 & 6120.283 & 6120.283 & 6120.283 \\
\hline Cyclopentane & 0 & 0 & 0 & 0 & 0 & 0 & 0 & 0 & 0 & 0 & 0 \\
\hline N-Pentadecane & 0 & 0 & 0 & 0 & 0 & 0 & 0 & 0 & 0 & 0 & 0 \\
\hline $\mathrm{N}$-Octadecane & 0 & 0 & 0 & 0 & 0 & 0 & 0 & 0 & 0 & 0 & 0 \\
\hline Tetralin & 0 & 0 & 0 & 0 & 0 & 0 & 0 & 0 & 0 & 0 & 0 \\
\hline Ethylbenzene & 0 & 0 & 0 & 0 & 0 & 0 & 0 & 0 & 0 & 0 & 0 \\
\hline Benzene & 0 & 0 & 0 & 0 & 0 & 0 & 0 & 0 & 0 & 0 & 0 \\
\hline N-Butane & 0 & 0 & 0 & 0 & 0 & 0 & 0 & 0 & 0 & 0 & 0 \\
\hline Toluene & 0 & 0 & 0 & 0 & 0 & 0 & 0 & 0 & 0 & 0 & 0 \\
\hline 1-3-5-Mesitylene & 0 & 0 & 0 & 0 & 0 & 0 & 0 & 0 & 0 & 0 & 0 \\
\hline P-Xylene & 0 & 0 & 0 & 0 & 0 & 0 & 1738.065 & 1738.064 & 1738.064 & 1738.064 & 1738.065 \\
\hline N-Propylbenzene & 0 & 0 & 0 & 0 & 0 & 0 & 0.0131 & 0.0102 & 0.0102 & 0.0102 & 0.0102 \\
\hline
\end{tabular}


Table A.2. (contd)

\begin{tabular}{|c|c|c|c|c|c|c|c|c|c|c|c|}
\hline Stream No. & 223 & 225 & 226 & 227 & 230 & 240 & 242 & 245 & 250 & 253 & 258 \\
\hline Temp F & 100 & 99.9329 & 99.9329 & 200 & 100 & 100 & 44.3597 & 100 & 77 & 84.6947 & 303.1303 \\
\hline Pres psig & 700.3041 & 35.3041 & 35.3041 & 35.3041 & 700.3041 & 700.3041 & 35 & 300 & 300 & 300 & 2500 \\
\hline Enth MMBtu/h & -33.374 & -0.07606 & -33.298 & -30.008 & -487.88 & -46.01 & -45.02 & -0.20059 & -0.90996 & -1.1106 & 6.2841 \\
\hline Vapor mass fraction & 0 & 1 & 0 & 0.000449 & 0 & 1 & 0.99656 & 1 & 1 & 1 & 1 \\
\hline Total lb/h & 69520.25 & 25.2322 & 69495.02 & 69495.01 & 72156.03 & 19698.48 & 16435.05 & 3263.436 & 6500 & 9763.431 & 9763.431 \\
\hline \multicolumn{12}{|l|}{ Flowrates in lb/h } \\
\hline Water & 242.2865 & 0.2879 & 241.9986 & 241.9986 & 71621.36 & 72.3108 & 72.3111 & 0 & 0 & 0 & 0 \\
\hline Hydrogen & 0.4663 & 0.455 & 0.0113 & 0.0113 & 3.7543 & 3839.336 & 575.9001 & 3263.436 & 6500 & 9763.431 & 9763.431 \\
\hline Carbon Dioxide & 31.1286 & 17.3243 & 13.8043 & 13.8043 & 250.624 & 8718.251 & 8718.251 & 0 & 0 & 0 & 0 \\
\hline Methane & 0.6464 & 0.6206 & 0.0258 & 0.0258 & 5.2046 & 3344.148 & 3344.149 & 0 & 0 & 0 & 0 \\
\hline Ethane & 0.5571 & 0.5241 & 0.0331 & 0.0331 & 0.0423 & 2006.3 & 2006.3 & 0 & 0 & 0 & 0 \\
\hline Propane & 730.0195 & 3.4583 & 726.5612 & 726.5612 & 17.2753 & 957.8062 & 957.8062 & 0 & 0 & 0 & 0 \\
\hline I-Butane & 889.0693 & 2.1131 & 886.9562 & 886.9562 & 6.5343 & 608.7963 & 608.7963 & 0 & 0 & 0 & 0 \\
\hline Pyro-lignin & 0 & 0 & 0 & 0 & 0 & 0 & 0 & 0 & 0 & 0 & 0 \\
\hline Cellobiose & 0 & 0 & 0 & 0 & 0.0051 & 0 & 0 & 0 & 0 & 0 & 0 \\
\hline Levoglucosan & 0 & 0 & 0 & 0 & 0.0014 & 0 & 0 & 0 & 0 & 0 & 0 \\
\hline Furfural & 0 & 0 & 0 & 0 & 0 & 0 & 0 & 0 & 0 & 0 & 0 \\
\hline HydroxyAcetone & 0 & 0 & 0 & 0 & 0 & 0 & 0 & 0 & 0 & 0 & 0 \\
\hline Acetic Acid & 0 & 0 & 0 & 0 & 0 & 0 & 0 & 0 & 0 & 0 & 0 \\
\hline 2-5-Xylenol & 7748.411 & 0.0064 & 7748.406 & 7748.406 & 249.3144 & 2.2761 & 2.2761 & 0 & 0 & 0 & 0 \\
\hline $\mathrm{N}$-Heptane & 3193.759 & 0.2507 & 3193.508 & 3193.508 & 0.7128 & 81.1817 & 81.1817 & 0 & 0 & 0 & 0 \\
\hline 1-ts-35-3С 1СусC6 & 4857.789 & 0.0991 & 4857.69 & 4857.689 & 0.1593 & 34.8195 & 34.8196 & 0 & 0 & 0 & 0 \\
\hline 3-3-5-TriMth-C7 & 1987.447 & 0.0195 & 1987.427 & 1987.427 & 0.015 & 7.2457 & 7.2457 & 0 & 0 & 0 & 0 \\
\hline N-PropylCyc-C6 & 4878.879 & 0.0392 & 4878.839 & 4878.839 & 0.1611 & 13.7284 & 13.7284 & 0 & 0 & 0 & 0 \\
\hline 1-2-3-Mesitylene & 641.6517 & 0.001 & 641.6508 & 641.6508 & 0.0785 & 0.3363 & 0.3363 & 0 & 0 & 0 & 0 \\
\hline N-ButylCycHexane & 233.9581 & 0.0007 & 233.9575 & 233.9575 & 0.0024 & 0.2423 & 0.2423 & 0 & 0 & 0 & 0 \\
\hline 1-2-DiC1-3C2-Bz & 1592.735 & 0.0012 & 1592.733 & 1592.733 & 0.0573 & 0.4248 & 0.4248 & 0 & 0 & 0 & 0 \\
\hline Cis-Decalin & 3184.489 & 0.0052 & 3184.483 & 3184.483 & 0.0499 & 1.8948 & 1.8948 & 0 & 0 & 0 & 0 \\
\hline Dimethyl-C11 & 8633.4 & 0.0045 & 8633.395 & 8633.395 & 0.0018 & 1.9188 & 1.9189 & 0 & 0 & 0 & 0 \\
\hline 1-2-4-triethylbe & 3186.106 & 0.0008 & 3186.105 & 3186.105 & 0.0099 & 0.3178 & 0.3178 & 0 & 0 & 0 & 0 \\
\hline 1-1-Bicyclohexyl & 238.9565 & 0.0001 & 238.9565 & 238.9565 & 0.0004 & 0.0256 & 0.0256 & 0 & 0 & 0 & 0 \\
\hline Diphenyl & 4383.134 & 0.0003 & 4383.133 & 4383.133 & 0.0454 & 0.1092 & 0.1092 & 0 & 0 & 0 & 0 \\
\hline diamantane & 8633.234 & 0.0054 & 8633.229 & 8633.229 & 0.0045 & 2.0826 & 2.0826 & 0 & 0 & 0 & 0 \\
\hline Phenanthrene & 6087.885 & 0 & 6087.884 & 6087.884 & 0.0107 & 0.0052 & 0.0052 & 0 & 0 & 0 & 0 \\
\hline N-C15-CycloC5 & 291.442 & 0 & 291.442 & 291.442 & 0 & 0.0001 & 0.0001 & 0 & 0 & 0 & 0 \\
\hline Hexatriacontane & 0 & 0 & 0 & 0 & 0 & 0 & 0 & 0 & 0 & 0 & 0 \\
\hline Chrysene & 6120.283 & 0 & 6120.283 & 6120.283 & 0.0003 & 0 & 0 & 0 & 0 & 0 & 0 \\
\hline Cyclopentane & 0 & 0 & 0 & 0 & 0 & 0 & 0 & 0 & 0 & 0 & 0 \\
\hline N-Pentadecane & 0 & 0 & 0 & 0 & 0 & 0 & 0 & 0 & 0 & 0 & 0 \\
\hline N-Octadecane & 0 & 0 & 0 & 0 & 0 & 0 & 0 & 0 & 0 & 0 & 0 \\
\hline Tetralin & 0 & 0 & 0 & 0 & 0 & 0 & 0 & 0 & 0 & 0 & 0 \\
\hline Ethylbenzene & 0 & 0 & 0 & 0 & 0 & 0 & 0 & 0 & 0 & 0 & 0 \\
\hline Benzene & 0 & 0 & 0 & 0 & 0 & 0 & 0 & 0 & 0 & 0 & 0 \\
\hline N-Butane & 0 & 0 & 0 & 0 & 0 & 0 & 0 & 0 & 0 & 0 & 0 \\
\hline Toluene & 0 & 0 & 0 & 0 & 0 & 0 & 0 & 0 & 0 & 0 & 0 \\
\hline 1-3-5-Mesitylene & 0 & 0 & 0 & 0 & 0 & 0 & 0 & 0 & 0 & 0 & 0 \\
\hline P-Xylene & 1732.51 & 0.015 & 1732.494 & 1732.494 & 0.6275 & 4.927 & 4.927 & 0 & 0 & 0 & 0 \\
\hline N-Propylbenzene & 0.0102 & 0 & 0.0102 & 0.0102 & 0 & 0 & 0 & 0 & 0 & 0 & 0 \\
\hline
\end{tabular}


Table A.2. (contd)

\begin{tabular}{|c|c|c|c|c|c|}
\hline Stream No. & 270 & 736 & 738 & 1820 & 1821 \\
\hline Temp F & 44.4289 & 700.0002 & 496.55 & 90 & 105 \\
\hline Pres psig & 35 & 645 & 645 & 60 & 55 \\
\hline Enth MMBtu/h & -45.096 & -22.468 & -25.758 & -2320.7 & -2315.6 \\
\hline Vapor mass fraction & 0.99656 & 1 & $1.00 \mathrm{E}-06$ & 0 & 0 \\
\hline Total lb/h & 16460.28 & 4037.127 & 4037.127 & 341022.1 & 341022.1 \\
\hline \multicolumn{6}{|l|}{ Flowrates in $\mathrm{lb} / \mathrm{h}$} \\
\hline Water & 72.5986 & 4037.127 & 4037.127 & 341022.1 & 341022.1 \\
\hline Hydrogen & 576.3552 & 0 & 0 & 0 & 0 \\
\hline Carbon Dioxide & 8735.575 & 0 & 0 & 0 & 0 \\
\hline Methane & 3344.769 & 0 & 0 & 0 & 0 \\
\hline Ethane & 2006.824 & 0 & 0 & 0 & 0 \\
\hline Propane & 961.2645 & 0 & 0 & 0 & 0 \\
\hline I-Butane & 610.9094 & 0 & 0 & 0 & 0 \\
\hline Pyro-lignin & 0 & 0 & 0 & 0 & 0 \\
\hline Cellobiose & 0 & 0 & 0 & 0 & 0 \\
\hline Levoglucosan & 0 & 0 & 0 & 0 & 0 \\
\hline Furfural & 0 & 0 & 0 & 0 & 0 \\
\hline HydroxyAcetone & 0 & 0 & 0 & 0 & 0 \\
\hline Acetic Acid & 0 & 0 & 0 & 0 & 0 \\
\hline 2-5-Xylenol & 2.2824 & 0 & 0 & 0 & 0 \\
\hline N-Heptane & 81.4324 & 0 & 0 & 0 & 0 \\
\hline 1-ts-35-3С1СусC6 & 34.9186 & 0 & 0 & 0 & 0 \\
\hline 3-3-5-TriMth-C7 & 7.2652 & 0 & 0 & 0 & 0 \\
\hline N-PropylCyc-C6 & 13.7676 & 0 & 0 & 0 & 0 \\
\hline 1-2-3-Mesitylene & 0.3373 & 0 & 0 & 0 & 0 \\
\hline N-ButylCycHexane & 0.243 & 0 & 0 & 0 & 0 \\
\hline 1-2-DiC1-3C2-Bz & 0.426 & 0 & 0 & 0 & 0 \\
\hline Cis-Decalin & 1.9 & 0 & 0 & 0 & 0 \\
\hline Dimethyl-C11 & 1.9233 & 0 & 0 & 0 & 0 \\
\hline 1-2-4-triethylbe & 0.3186 & 0 & 0 & 0 & 0 \\
\hline 1-1-Bicyclohexyl & 0.0257 & 0 & 0 & 0 & 0 \\
\hline Diphenyl & 0.1094 & 0 & 0 & 0 & 0 \\
\hline diamantane & 2.088 & 0 & 0 & 0 & 0 \\
\hline Phenanthrene & 0.0052 & 0 & 0 & 0 & 0 \\
\hline N-C15-CycloC5 & 0.0001 & 0 & 0 & 0 & 0 \\
\hline Hexatriacontane & 0 & 0 & 0 & 0 & 0 \\
\hline Chrysene & 0 & 0 & 0 & 0 & 0 \\
\hline Cyclopentane & 0 & 0 & 0 & 0 & 0 \\
\hline N-Pentadecane & 0 & 0 & 0 & 0 & 0 \\
\hline N-Octadecane & 0 & 0 & 0 & 0 & 0 \\
\hline Tetralin & 0 & 0 & 0 & 0 & 0 \\
\hline Ethylbenzene & 0 & 0 & 0 & 0 & 0 \\
\hline Benzene & 0 & 0 & 0 & 0 & 0 \\
\hline N-Butane & 0 & 0 & 0 & 0 & 0 \\
\hline Toluene & 0 & 0 & 0 & 0 & 0 \\
\hline 1-3-5-Mesitylene & 0 & 0 & 0 & 0 & 0 \\
\hline P-Xylene & 4.942 & 0 & 0 & 0 & 0 \\
\hline N-Propylbenzene & 0 & 0 & 0 & 0 & 0 \\
\hline
\end{tabular}




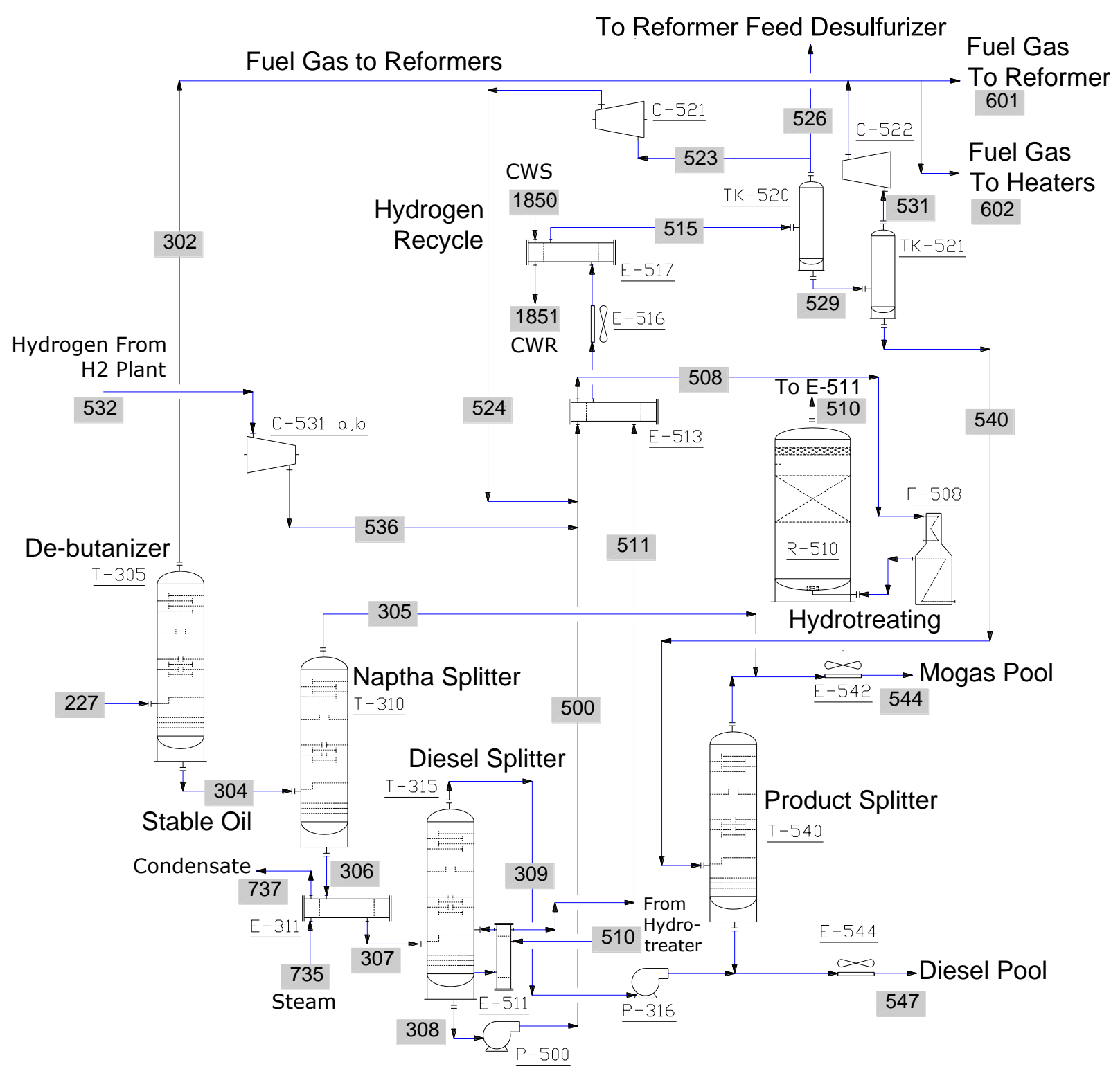

Figure A.3. Flow Diagram for Hydrocracking and Product Separation 
Table A.3. Hydrocracking and Product Separation Heat and Material Balance

\begin{tabular}{|c|c|c|c|c|c|c|c|c|c|c|c|}
\hline Stream No. & 227 & 302 & 304 & 305 & 306 & 307 & 308 & 309 & 310 & 500 & 508 \\
\hline Temp F & 200 & 203.3611 & 457.477 & 308.4405 & 427.7641 & 470 & 734.4869 & 398.6693 & 398.8038 & 744.7188 & 366 \\
\hline Pres psig & 35.3041 & 35.3041 & 35.3041 & 5 & 5 & 2 & 1 & 1 & 15 & 1300 & 1295 \\
\hline Enth MMBtu/h & -30.008 & -4.1857 & -15.689 & -12.8 & -5.6145 & -1.3824 & 5.6133 & -10.415 & -10.413 & 5.6658 & 5.651 \\
\hline Vapor mass fraction & 0.000449 & 1 & 0 & 0 & 0 & 0.52048 & 0 & 0 & 0 & 0 & 0.20116 \\
\hline Total lb/h & 69495.01 & 3466.51 & 66028.52 & 19360.17 & 46668.37 & 46668.38 & 8800.003 & 37868.36 & 37868.37 & 8800.005 & 11010 \\
\hline \multicolumn{12}{|l|}{ Flowrates in lb/h } \\
\hline Water & 241.9986 & 241.9984 & 0 & 0 & 0 & 0 & 0 & 0 & 0 & 0 & 0 \\
\hline Hybrid Poplar Ch & 0 & 0 & 0 & 0 & 0 & 0 & 0 & 0 & 0 & 0 & 0 \\
\hline Hydrogen & 0.0113 & 0.0113 & 0 & 0 & 0 & 0 & 0 & 0 & 0 & 0 & 2129.363 \\
\hline Carbon Dioxide & 13.8043 & 13.8043 & 0 & 0 & 0 & 0 & 0 & 0 & 0 & 0 & 0 \\
\hline Methane & 0.0258 & 0.0258 & 0 & 0 & 0 & 0 & 0 & 0 & 0 & 0 & 0 \\
\hline Ethane & 0.0331 & 0.0331 & 0 & 0 & 0 & 0 & 0 & 0 & 0 & 0 & 0 \\
\hline Propane & 726.5612 & 726.5609 & 0 & 0 & 0 & 0 & 0 & 0 & 0 & 0 & 0 \\
\hline I-Butane & 886.9562 & 886.956 & 0 & 0 & 0 & 0 & 0 & 0 & 0 & 0 & 0 \\
\hline 2-5-Xylenol & 7748.406 & 0.0001 & 7748.407 & 3162.434 & 4585.977 & 4585.977 & 0.0083 & 4585.968 & 4585.968 & 0.0083 & 0.0083 \\
\hline N-Heptane & 3193.508 & 1596.752 & 1596.765 & 1596.766 & 0 & 0 & 0 & 0 & 0 & 0 & 0 \\
\hline 1-ts-35-3С1СусC6 & 4857.689 & 0.0486 & 4857.643 & 4541.519 & 316.1233 & 316.1233 & 0.0016 & 316.1216 & 316.1216 & 0.0016 & 0.0016 \\
\hline 3-3-5-TriMth-C7 & 1987.427 & 0.0002 & 1987.428 & 1856.982 & 130.4458 & 130.4458 & 0.0003 & 130.4456 & 130.4456 & 0.0003 & 0.0003 \\
\hline N-PropylCyc-C6 & 4878.839 & 0.0006 & 4878.839 & 3903.073 & 975.7652 & 975.7652 & 0.0087 & 975.7564 & 975.7565 & 0.0087 & 0.0087 \\
\hline 1-2-3-Mesitylene & 641.6508 & 0 & 641.6508 & 128.3304 & 513.3206 & 513.3206 & 0.0191 & 513.3015 & 513.3015 & 0.0191 & 0.0191 \\
\hline N-ButylCycHexane & 233.9575 & 0 & 233.9575 & 125.987 & 107.9707 & 107.9707 & 0.0016 & 107.9691 & 107.9691 & 0.0016 & 0.0016 \\
\hline 1-2-DiC1-3C2-Bz & 1592.733 & 0 & 1592.733 & 135.2346 & 1457.499 & 1457.499 & 0.0871 & 1457.412 & 1457.412 & 0.0871 & 0.0871 \\
\hline Cis-Decalin & 3184.483 & 0 & 3184.484 & 1024.104 & 2160.379 & 2160.379 & 0.0983 & 2160.281 & 2160.281 & 0.0983 & 0.0984 \\
\hline Dimethyl-C11 & 8633.395 & 0 & 8633.397 & 1406.676 & 7226.72 & 7226.72 & 0.0961 & 7226.625 & 7226.625 & 0.0961 & 0.0961 \\
\hline 1-2-4-triethylbe & 3186.105 & 0 & 3186.106 & 49.8727 & 3136.233 & 3136.233 & 0.2496 & 3135.983 & 3135.984 & 0.2496 & 0.2497 \\
\hline 1-1-Bicyclohexyl & 238.9565 & 0 & 238.9565 & 4.0338 & 234.9227 & 234.9227 & 0.035 & 234.8877 & 234.8877 & 0.035 & 0.035 \\
\hline Diphenyl & 4383.133 & 0 & 4383.134 & 2.1702 & 4380.966 & 4380.966 & 6.4693 & 4374.497 & 4374.496 & 6.4693 & 6.4695 \\
\hline diamantane & 8633.229 & 0 & 8633.231 & 174.8519 & 8458.38 & 8458.38 & 15.8027 & 8442.577 & 8442.577 & 15.8027 & 15.8052 \\
\hline Phenanthrene & 6087.884 & 0 & 6087.887 & 0 & 6087.889 & 6087.889 & 2653.667 & 3434.22 & 3434.221 & 2653.668 & 2653.667 \\
\hline N-C15-CycloC5 & 291.442 & 0 & 291.442 & 0 & 291.4421 & 291.4421 & 3.1626 & 288.2794 & 288.2794 & 3.1626 & 3.1626 \\
\hline Chrysene & 6120.283 & 0 & 6120.284 & 0 & 6120.288 & 6120.288 & 6120.288 & 0.0001 & 0.0001 & 6120.288 & 6120.286 \\
\hline 1-Pentene & 0 & 0 & 0 & 0 & 0 & 0 & 0 & 0 & 0 & 0 & 0 \\
\hline O-Xylene & 0 & 0 & 0 & 0 & 0 & 0 & 0 & 0 & 0 & 0 & 0 \\
\hline Cyclopentane & 0 & 0 & 0 & 0 & 0 & 0 & 0 & 0 & 0 & 0 & 0.0552 \\
\hline N-Pentadecane & 0 & 0 & 0 & 0 & 0 & 0 & 0 & 0 & 0 & 0 & 0 \\
\hline $\mathrm{N}$-Octadecane & 0 & 0 & 0 & 0 & 0 & 0 & 0 & 0 & 0 & 0 & 0 \\
\hline Tetralin & 0 & 0 & 0 & 0 & 0 & 0 & 0 & 0 & 0 & 0 & 0.0439 \\
\hline Ethylbenzene & 0 & 0 & 0 & 0 & 0 & 0 & 0 & 0 & 0 & 0 & 0 \\
\hline Benzene & 0 & 0 & 0 & 0 & 0 & 0 & 0 & 0 & 0 & 0 & 0 \\
\hline N-Butane & 0 & 0 & 0 & 0 & 0 & 0 & 0 & 0 & 0 & 0 & 28.8114 \\
\hline Toluene & 0 & 0 & 0 & 0 & 0 & 0 & 0 & 0 & 0 & 0 & 0 \\
\hline 1-3-5-Mesitylene & 0 & 0 & 0 & 0 & 0 & 0 & 0 & 0 & 0 & 0 & 0 \\
\hline P-Xylene & 1732.494 & 0.3188 & 1732.176 & 1248.131 & 484.0454 & 484.0454 & 0.0088 & 484.0365 & 484.0366 & 0.0088 & 0.0088 \\
\hline N-Propylbenzene & 0.0102 & 0 & 0.0102 & 0.0064 & 0.0038 & 0.0038 & 0 & 0.0038 & 0.0038 & 0 & 0 \\
\hline N-Butylbenzene & 0 & 0 & 0 & 0 & 0 & 0 & 0 & 0 & 0 & 0 & 0 \\
\hline O-Ethyltoluene & 0 & 0 & 0 & 0 & 0 & 0 & 0 & 0 & 0 & 0 & 0 \\
\hline $\mathrm{C} 9 \mathrm{H} 18$ & 0 & 0 & 0 & 0 & 0 & 0 & 0 & 0 & 0 & 0 & 13.652 \\
\hline MthCyclohexane & 0 & 0 & 0 & 0 & 0 & 0 & 0 & 0 & 0 & 0 & 38.0712 \\
\hline
\end{tabular}


Table A.3. (contd)

\begin{tabular}{|c|c|c|c|c|c|c|c|c|c|c|c|}
\hline Stream No. & 510 & 511 & 515 & 523 & 524 & 526 & 529 & 531 & 532 & 536 & 540 \\
\hline Temp F & 1247.858 & 402.8347 & 110 & 110 & 118.5025 & 110 & 110 & 109.9931 & 77 & 95 & 109.9931 \\
\hline Pres psig & 1275 & 1275 & 1255 & 1255 & 1300 & 1255 & 1255 & 1 & 300 & 1300 & 1 \\
\hline Enth MMBtu/h & 5.6979 & -4.3021 & -7.9143 & -0.09247 & -0.06215 & -0.01709 & -7.8047 & -0.00062 & -0.15399 & -0.08641 & -7.8041 \\
\hline Vapor mass fraction & 1 & 0.6392 & 0.11945 & 1 & 1 & 1 & 0 & 1 & 1 & 1 & 0 \\
\hline Total lb/h & 11010.12 & 11010.12 & 11010.12 & 1110 & 1110 & 205.1373 & 9694.978 & 0.9811 & 1100 & 1100 & 9694 \\
\hline \multicolumn{12}{|l|}{ Flowrates in lb/h } \\
\hline Water & 0 & 0 & 0 & 0 & 0 & 0 & 0 & 0 & 0 & 0 & 0 \\
\hline Hybrid Poplar Ch & 0 & 0 & 0 & 0 & 0 & 0 & 0 & 0 & 0 & 0 & 0 \\
\hline Hydrogen & 1219.721 & 1219.721 & 1219.77 & 1029.363 & 1029.363 & 190.2349 & 0.172 & 0.1702 & 1100 & 1100 & 0.0018 \\
\hline Carbon Dioxide & 0 & 0 & 0 & 0 & 0 & 0 & 0 & 0 & 0 & 0 & 0 \\
\hline Methane & 0 & 0 & 0 & 0 & 0 & 0 & 0 & 0 & 0 & 0 & 0 \\
\hline Ethane & 0 & 0 & 0 & 0 & 0 & 0 & 0 & 0 & 0 & 0 & 0 \\
\hline Propane & 0 & 0 & 0 & 0 & 0 & 0 & 0 & 0 & 0 & 0 & 0 \\
\hline I-Butane & 0 & 0 & 0 & 0 & 0 & 0 & 0 & 0 & 0 & 0 & 0 \\
\hline 2-5-Xylenol & 0.0083 & 0.0083 & 0.0083 & 0.0001 & 0.0001 & 0 & 0.0083 & 0 & 0 & 0 & 0.0083 \\
\hline N-Heptane & 0 & 0 & 0 & 0 & 0 & 0 & 0 & 0 & 0 & 0 & 0 \\
\hline 1-ts-35-3С1СycС6 & 0.0016 & 0.0016 & 0.0016 & 0 & 0 & 0 & 0.0016 & 0 & 0 & 0 & 0.0016 \\
\hline 3-3-5-TriMth-C7 & 0.0003 & 0.0003 & 0.0003 & 0 & 0 & 0 & 0.0003 & 0 & 0 & 0 & 0.0003 \\
\hline N-PropylCyc-C6 & 0.0087 & 0.0087 & 0.0087 & 0 & 0 & 0 & 0.0087 & 0 & 0 & 0 & 0.0087 \\
\hline 1-2-3-Mesitylene & 0.0191 & 0.0191 & 0.0191 & 0 & 0 & 0 & 0.0191 & 0 & 0 & 0 & 0.0191 \\
\hline N-ButylCycHexane & 0.0016 & 0.0016 & 0.0016 & 0 & 0 & 0 & 0.0016 & 0 & 0 & 0 & 0.0016 \\
\hline 1-2-DiC1-3C2-Bz & 0.0871 & 0.0871 & 0.0871 & 0 & 0 & 0 & 0.0871 & 0 & 0 & 0 & 0.0871 \\
\hline Cis-Decalin & 0.0984 & 0.0984 & 0.0984 & 0 & 0 & 0 & 0.0983 & 0 & 0 & 0 & 0.0983 \\
\hline Dimethyl-C11 & 0.0961 & 0.0961 & 0.0961 & 0 & 0 & 0 & 0.0961 & 0 & 0 & 0 & 0.0961 \\
\hline 1-2-4-triethylbe & 0.2497 & 0.2497 & 0.2497 & 0 & 0 & 0 & 0.2496 & 0 & 0 & 0 & 0.2496 \\
\hline 1-1-Bicyclohexyl & 0.035 & 0.035 & 0.035 & 0 & 0 & 0 & 0.035 & 0 & 0 & 0 & 0.035 \\
\hline Diphenyl & 6.4695 & 6.4695 & 6.4695 & 0.0002 & 0.0002 & 0 & 6.4693 & 0 & 0 & 0 & 6.4693 \\
\hline diamantane & 15.8052 & 15.8052 & 15.8052 & 0.0026 & 0.0026 & 0.0005 & 15.8022 & 0 & 0 & 0 & 15.8022 \\
\hline Phenanthrene & 0 & 0 & 0 & 0 & 0 & 0 & 0 & 0 & 0 & 0 & 0 \\
\hline N-C15-CycloC5 & 0.0032 & 0.0032 & 0.0032 & 0 & 0 & 0 & 0.0032 & 0 & 0 & 0 & 0.0032 \\
\hline Chrysene & 0 & 0 & 0 & 0 & 0 & 0 & 0 & 0 & 0 & 0 & 0 \\
\hline 1-Pentene & 0 & 0 & 0 & 0 & 0 & 0 & 0 & 0 & 0 & 0 & 0 \\
\hline O-Xylene & 0 & 0 & 0 & 0 & 0 & 0 & 0 & 0 & 0 & 0 & 0 \\
\hline Cyclopentane & 0.8451 & 0.8451 & 0.845 & 0.0552 & 0.0552 & 0.0102 & 0.7796 & 0.0006 & 0 & 0 & 0.779 \\
\hline N-Pentadecane & 2.3923 & 2.3923 & 2.3923 & 0 & 0 & 0 & 2.3923 & 0 & 0 & 0 & 2.3923 \\
\hline $\mathrm{N}$-Octadecane & 0 & 0 & 0 & 0 & 0 & 0 & 0 & 0 & 0 & 0 & 0 \\
\hline Tetralin & 196.8838 & 196.8838 & 196.8838 & 0.0439 & 0.0439 & 0.0081 & 196.8318 & 0.0004 & 0 & 0 & 196.8314 \\
\hline Ethylbenzene & 0 & 0 & 0 & 0 & 0 & 0 & 0 & 0 & 0 & 0 & 0 \\
\hline Benzene & 0 & 0 & 0 & 0 & 0 & 0 & 0 & 0 & 0 & 0 & 0 \\
\hline N-Butane & 115.3507 & 115.3507 & 115.3013 & 28.8121 & 28.8121 & 5.3247 & 81.1645 & 0.2964 & 0 & 0 & 80.8681 \\
\hline Toluene & 0 & 0 & 0 & 0 & 0 & 0 & 0 & 0 & 0 & 0 & 0 \\
\hline 1-3-5-Mesitylene & 0 & 0 & 0 & 0 & 0 & 0 & 0 & 0 & 0 & 0 & 0 \\
\hline P-Xylene & 0.0088 & 0.0088 & 0.0088 & 0 & 0 & 0 & 0.0088 & 0 & 0 & 0 & 0.0088 \\
\hline N-Propylbenzene & 0 & 0 & 0 & 0 & 0 & 0 & 0 & 0 & 0 & 0 & 0 \\
\hline N-Butylbenzene & 0 & 0 & 0 & 0 & 0 & 0 & 0 & 0 & 0 & 0 & 0 \\
\hline O-Ethyltoluene & 0 & 0 & 0 & 0 & 0 & 0 & 0 & 0 & 0 & 0 & 0 \\
\hline $\mathrm{C} 9 \mathrm{H} 18$ & 6782.503 & 6782.503 & 6782.505 & 13.652 & 13.652 & 2.523 & 6766.33 & 0.1299 & 0 & 0 & 6766.2 \\
\hline MthCyclohexane & 2669.528 & 2669.528 & 2669.527 & 38.0711 & 38.0711 & 7.0359 & 2624.419 & 0.3836 & 0 & 0 & 2624.036 \\
\hline
\end{tabular}


Table A.3. (contd)

\begin{tabular}{|c|c|c|c|c|c|c|c|c|c|c|c|}
\hline Stream No. & 544 & 547 & 601 & 602 & 735 & 737 & 1850 & 1851 & & & \\
\hline Temp F & 150 & 150 & 85.0536 & 85.0536 & 700.0002 & 496.55 & 90 & 105 & & & \\
\hline Pres psig & 1 & 15 & 35 & 35 & 645 & 645 & 45.3041 & 40.3041 & & & \\
\hline Enth MMBtu/h & -21.85 & -15.53 & -39.134 & -10.149 & -28.903 & -33.135 & -129.5 & -129.21 & & & \\
\hline Vapor mass fraction & 0 & 0 & 0.98769 & 0.98769 & 1 & $1.00 \mathrm{E}-06$ & 0 & 0 & & & \\
\hline Total lb/h & 28555.25 & 38367.25 & 15824.14 & 4103.631 & 5193.402 & 5193.402 & 19029.97 & 19029.96 & & & \\
\hline \multicolumn{12}{|l|}{ Flowrates in lb/h } \\
\hline Water & 0 & 0 & 249.8139 & 64.7836 & 5193.402 & 5193.402 & 19029.97 & 19029.96 & & & \\
\hline Hybrid Poplar Ch & 0 & 0 & 0 & 0 & 0 & 0 & 0 & 0 & & & \\
\hline Hydrogen & 0.0018 & 0 & 457.8133 & 118.7234 & 0 & 0 & 0 & 0 & & & \\
\hline Carbon Dioxide & 0 & 0 & 6947.662 & 1801.718 & 0 & 0 & 0 & 0 & & & \\
\hline Methane & 0 & 0 & 2656.017 & 688.7776 & 0 & 0 & 0 & 0 & & & \\
\hline Ethane & 0 & 0 & 1593.595 & 413.2626 & 0 & 0 & 0 & 0 & & & \\
\hline Propane & 0 & 0 & 1340.26 & 347.5659 & 0 & 0 & 0 & 0 & & & \\
\hline I-Butane & 0 & 0 & 1189.417 & 308.4483 & 0 & 0 & 0 & 0 & & & \\
\hline 2-5-Xylenol & 3162.44 & 4585.968 & 1.8125 & 0.47 & 0 & 0 & 0 & 0 & & & \\
\hline N-Heptane & 1596.764 & 0 & 1332.604 & 345.5806 & 0 & 0 & 0 & 0 & & & \\
\hline 1-ts-35-3С1СycC6 & 4541.518 & 316.1217 & 27.7666 & 7.2006 & 0 & 0 & 0 & 0 & & & \\
\hline 3-3-5-TriMth-C7 & 1856.981 & 130.4455 & 5.7693 & 1.4961 & 0 & 0 & 0 & 0 & & & \\
\hline N-PropylCyc-C6 & 3903.079 & 975.7582 & 10.933 & 2.8352 & 0 & 0 & 0 & 0 & & & \\
\hline 1-2-3-Mesitylene & 128.3341 & 513.3166 & 0.2678 & 0.0695 & 0 & 0 & 0 & 0 & & & \\
\hline N-ButylCycHexane & 125.9872 & 107.9704 & 0.193 & 0.05 & 0 & 0 & 0 & 0 & & & \\
\hline 1-2-DiC1-3C2-Bz & 135.2398 & 1457.493 & 0.3383 & 0.0877 & 0 & 0 & 0 & 0 & & & \\
\hline Cis-Decalin & 1024.112 & 2160.371 & 1.5088 & 0.3913 & 0 & 0 & 0 & 0 & & & \\
\hline Dimethyl-C11 & 1406.674 & 7226.722 & 1.5272 & 0.3961 & 0 & 0 & 0 & 0 & & & \\
\hline 1-2-4-triethylbe & 49.8727 & 3136.233 & 0.253 & 0.0656 & 0 & 0 & 0 & 0 & & & \\
\hline 1-1-Bicyclohexyl & 4.0338 & 234.9227 & 0.0204 & 0.0053 & 0 & 0 & 0 & 0 & & & \\
\hline Diphenyl & 2.1701 & 4380.964 & 0.0869 & 0.0225 & 0 & 0 & 0 & 0 & & & \\
\hline diamantane & 174.8532 & 8458.38 & 1.6581 & 0.43 & 0 & 0 & 0 & 0 & & & \\
\hline Phenanthrene & 0 & 3434.22 & 0.0042 & 0.0011 & 0 & 0 & 0 & 0 & & & \\
\hline N-C15-CycloC5 & 0 & 288.2826 & 0.0001 & 0 & 0 & 0 & 0 & 0 & & & \\
\hline Chrysene & 0 & 0.0001 & 0 & 0 & 0 & 0 & 0 & 0 & & & \\
\hline 1-Pentene & 0 & 0 & 0 & 0 & 0 & 0 & 0 & 0 & & & \\
\hline O-Xylene & 0 & 0 & 0 & 0 & 0 & 0 & 0 & 0 & & & \\
\hline Cyclopentane & 0.779 & 0 & 0.0005 & 0.0001 & 0 & 0 & 0 & 0 & & & \\
\hline N-Pentadecane & 0 & 2.3923 & 0 & 0 & 0 & 0 & 0 & 0 & & & \\
\hline $\mathrm{N}$-Octadecane & 0 & 0 & 0 & 0 & 0 & 0 & 0 & 0 & & & \\
\hline Tetralin & 4.8831 & 191.9483 & 0.0003 & 0.0001 & 0 & 0 & 0 & 0 & & & \\
\hline Ethylbenzene & 0 & 0 & 0 & 0 & 0 & 0 & 0 & 0 & & & \\
\hline Benzene & 0 & 0 & 0 & 0 & 0 & 0 & 0 & 0 & & & \\
\hline N-Butane & 80.868 & 0 & 0.2354 & 0.061 & 0 & 0 & 0 & 0 & & & \\
\hline Toluene & 0 & 0 & 0 & 0 & 0 & 0 & 0 & 0 & & & \\
\hline 1-3-5-Mesitylene & 0 & 0 & 0 & 0 & 0 & 0 & 0 & 0 & & & \\
\hline P-Xylene & 1248.139 & 484.0367 & 4.1775 & 1.0833 & 0 & 0 & 0 & 0 & & & \\
\hline N-Propylbenzene & 0.0064 & 0.0038 & 0 & 0 & 0 & 0 & 0 & 0 & & & \\
\hline N-Butylbenzene & 0 & 0 & 0 & 0 & 0 & 0 & 0 & 0 & & & \\
\hline O-Ethyltoluene & 0 & 0 & 0 & 0 & 0 & 0 & 0 & 0 & & & \\
\hline $\mathrm{C} 9 \mathrm{H} 18$ & 6484.484 & 281.7122 & 0.1032 & 0.0268 & 0 & 0 & 0 & 0 & & & \\
\hline MthCyclohexane & 2624.033 & 0 & 0.3046 & 0.079 & 0 & 0 & 0 & 0 & & & \\
\hline
\end{tabular}




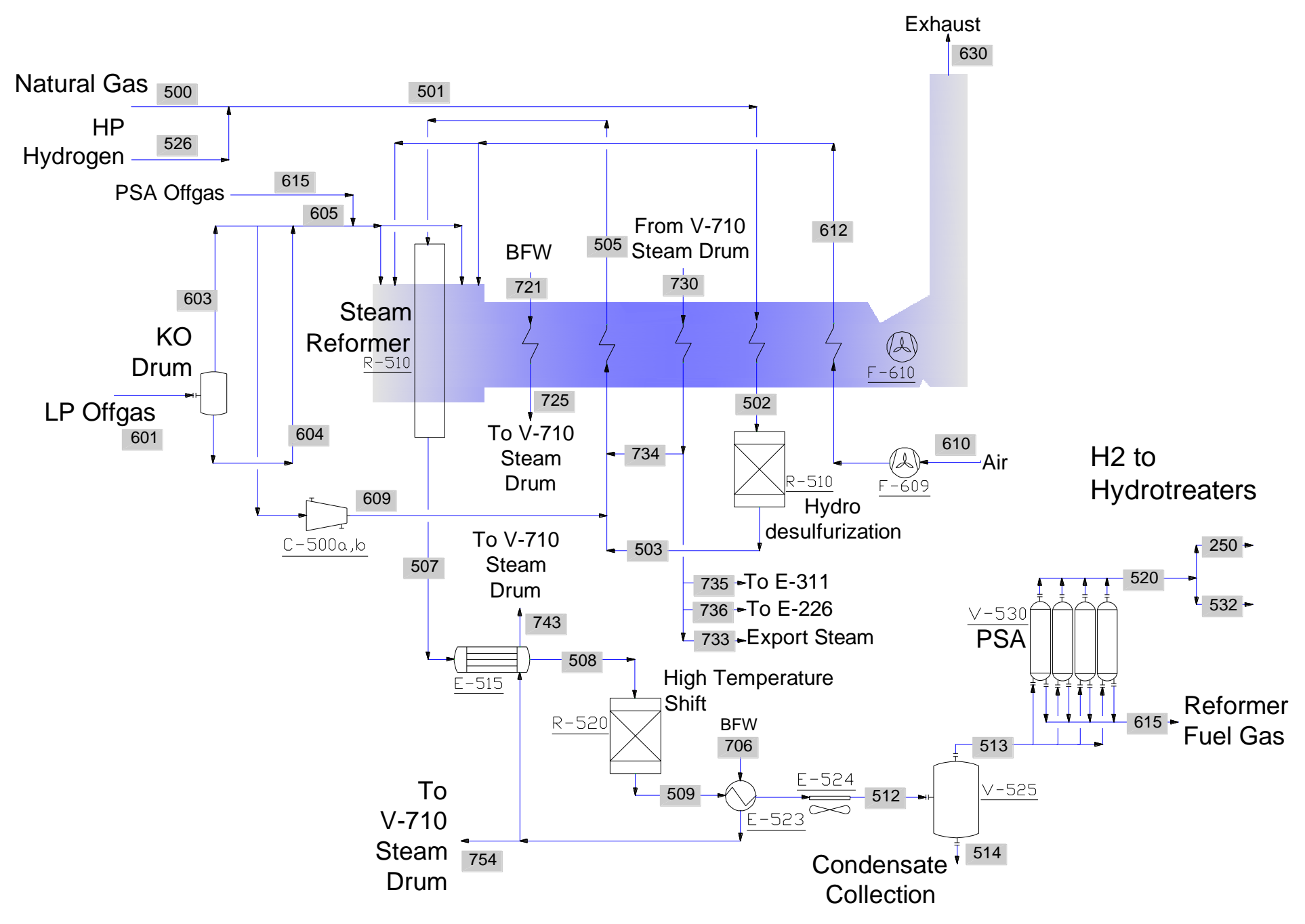

Figure A.4. Flow Diagram for Hydrogen Generation by Steam Reforming 
Table A.4. Hydrogen Generation by Steam Reforming Heat and Material Balance

\begin{tabular}{|c|c|c|c|c|c|c|c|c|c|c|c|}
\hline Stream No. & 250 & 532 & 500 & 501 & 502 & 503 & 505 & 507 & 508 & 509 & 512 \\
\hline Temp F & 77 & 77 & 60 & 61.8717 & 700 & 700 & 1050 & 1562 & 549.1881 & 667.5483 & 150 \\
\hline Pres psig & 300 & 300 & 400 & 400 & 399.5 & 399.5 & 389.5 & 359.5 & 354.5 & 344.5 & 329.5 \\
\hline Enth MMBtu/h & -0.90996 & -0.15399 & -34.902 & -34.892 & -26.96 & -26.96 & -498.35 & -367.68 & -440.7 & -440.7 & -526.32 \\
\hline Vapor mass fraction & 1 & 1 & 1 & 1 & 1 & 1 & 1 & 1 & 1 & 1 & 0.53835 \\
\hline Total lb/h & 6500 & 1100 & 17196.06 & 17401.2 & 17401.2 & 17401.2 & 110098.3 & 110098.4 & 110098.4 & 110098.8 & 110098.8 \\
\hline \multicolumn{12}{|l|}{ Flowrates in lb/h } \\
\hline Water & 0 & 0 & 0 & 0 & 0 & 0 & 88044.1 & 60993.9 & 60993.9 & 51908.3 & 51908.3 \\
\hline Hydrogen & 6500.0 & 1100.0 & 0.0 & 190.2 & 190.2 & 190.2 & 327.6 & 7450.3 & 7450.3 & 8466.9 & 8466.9 \\
\hline Carbon & 0 & 0 & 0 & 0 & 0 & 0 & 0 & 0 & 0 & 0 & 0 \\
\hline Carbon Monoxide & 0 & 0 & 0 & 0 & 0 & 0 & 0 & 17026.3 & 17026.3 & 2899.8 & 2899.8 \\
\hline Carbon Dioxide & 0 & 0 & 0 & 0 & 0 & 0 & 2084.2 & 21749.5 & 21749.5 & 43945.3 & 43945.3 \\
\hline Methane & 0 & 0 & 17196.1 & 17196.1 & 17196.1 & 17196.1 & 17992.9 & 2878.1 & 2878.1 & 2878.1 & 2878.1 \\
\hline Ethylene & 0 & 0 & 0 & 0 & 0 & 0 & 0 & 0 & 0 & 0 & 0 \\
\hline Ethane & 0 & 0 & 0 & 0 & 0 & 0 & 478.0 & 0.1 & 0.1 & 0.1 & 0.1 \\
\hline Propylene & 0 & 0 & 0 & 0 & 0 & 0 & 0 & 0 & 0 & 0 & 0 \\
\hline Propane & 0 & 0 & 0 & 0 & 0 & 0 & 401.9 & 0 & 0 & 0 & 0 \\
\hline I-Butane & 0 & 0 & 0 & 0 & 0 & 0 & 356.5 & 0 & 0 & 0 & 0 \\
\hline Formaldehyde & 0 & 0 & 0 & 0 & 0 & 0 & 0 & 0.2 & 0.2 & 0.2 & 0.2 \\
\hline 2-5-Xylenol & 0 & 0 & 0 & 0 & 0 & 0 & 0.1 & 0 & 0 & 0 & 0 \\
\hline $\mathrm{N}$-Heptane & 0 & 0 & 0 & 0 & 0 & 0 & 385.5 & 0 & 0 & 0 & 0 \\
\hline 1-ts-35-3С1 СycC6 & 0 & 0 & 0 & 0 & 0 & 0 & 6.9 & 0 & 0 & 0 & 0 \\
\hline 3-3-5-TriMth-C7 & 0 & 0 & 0 & 0 & 0 & 0 & 1.3 & 0 & 0 & 0 & 0 \\
\hline N-PropylCyc-C6 & 0 & 0 & 0 & 0 & 0 & 0 & 2.6 & 0 & 0 & 0 & 0 \\
\hline 1-2-3-Mesitylene & 0 & 0 & 0 & 0 & 0 & 0 & 0 & 0 & 0 & 0 & 0 \\
\hline N-ButylCycHexane & 0 & 0 & 0 & 0 & 0 & 0 & 0 & 0 & 0 & 0 & 0 \\
\hline 1-2-DiC1-3C2-Bz & 0 & 0 & 0 & 0 & 0 & 0 & 0 & 0 & 0 & 0 & 0 \\
\hline Cis-Decalin & 0 & 0 & 0 & 0 & 0 & 0 & 0.2 & 0 & 0 & 0 & 0 \\
\hline Dimethyl-C11 & 0 & 0 & 0 & 0 & 0 & 0 & 0.1 & 0 & 0 & 0 & 0 \\
\hline 1-2-4-triethylbe & 0 & 0 & 0 & 0 & 0 & 0 & 0 & 0 & 0 & 0 & 0 \\
\hline 1-1-Bicyclohexyl & 0 & 0 & 0 & 0 & 0 & 0 & 0 & 0 & 0 & 0 & 0 \\
\hline Diphenyl & 0 & 0 & 0 & 0 & 0 & 0 & 0 & 0 & 0 & 0 & 0 \\
\hline diamantane & 0 & 0 & 0 & 0 & 0 & 0 & 0.1 & 0 & 0 & 0 & 0 \\
\hline Phenanthrene & 0 & 0 & 0 & 0 & 0 & 0 & 0 & 0 & 0 & 0 & 0 \\
\hline N-C15-CycloC5 & 0 & 0 & 0 & 0 & 0 & 0 & 0 & 0 & 0 & 0 & 0 \\
\hline Cyclopentane & 0 & 0 & 0 & 0 & 0 & 0 & 0 & 0 & 0 & 0 & 0 \\
\hline $\mathrm{N}$-Pentadecane & 0 & 0 & 0 & 0 & 0 & 0 & 0 & 0 & 0 & 0 & 0 \\
\hline $\mathrm{N}$-Octadecane & 0 & 0 & 0 & 0 & 0 & 0 & 0 & 0 & 0 & 0 & 0 \\
\hline Tetralin & 0 & 0 & 0 & 0 & 0 & 0 & 0 & 0 & 0 & 0 & 0 \\
\hline Ethylbenzene & 0 & 0 & 0 & 0 & 0 & 0 & 0 & 0 & 0 & 0 & 0 \\
\hline Benzene & 0 & 0 & 0 & 0 & 0 & 0 & 0 & 0 & 0 & 0 & 0 \\
\hline N-Butane & 0 & 0 & 0 & 5.3 & 5.3 & 5.3 & 5.4 & 0 & 0 & 0 & 0 \\
\hline Toluene & 0 & 0 & 0 & 0 & 0 & 0 & 0 & 0 & 0 & 0 & 0 \\
\hline 1-3-5-Mesitylene & 0 & 0 & 0 & 0 & 0 & 0 & 0 & 0 & 0 & 0 & 0 \\
\hline P-Xylene & 0 & 0 & 0 & 0 & 0 & 0 & 1.1 & 0 & 0 & 0 & 0 \\
\hline $\mathrm{C} 9 \mathrm{H} 18$ & 0 & 0 & 0 & 2.5 & 2.5 & 2.5 & 2.5 & 0 & 0 & 0 & 0 \\
\hline MthCyclohexane & 0 & 0 & 0 & 7.0 & 7.0 & 7.0 & 7.1 & 0 & 0 & 0 & 0 \\
\hline
\end{tabular}


Table A.4. (contd)

\begin{tabular}{|c|c|c|c|c|c|c|c|c|c|c|c|}
\hline Stream No. & 513 & 514 & 520 & 526 & 601 & 603 & 604 & 605 & 609 & 610 & 612 \\
\hline Temp F & 150 & 150 & 150 & 110 & 85.0536 & 85.0536 & 85.0536 & 85.0536 & 256.2011 & 60 & 550 \\
\hline Pres psig & 329.5 & 329.5 & 329.5 & 1255 & 35 & 35 & 35 & 35 & 400 & 0.001 & 2 \\
\hline Enth MMBtu/h & -183.1 & -343.22 & 1.9013 & 0.009921 & -39.131 & -38.37 & -0.76068 & -26.859 & -11.172 & -0.97388 & 26.657 \\
\hline Vapor mass fraction & 1 & 0 & 1 & 1 & 0.98944 & 1 & 0 & 1 & 1 & 1 & 1 \\
\hline Total lb/h & 59271.69 & 50827.07 & 7620.208 & 205.1373 & 15824.14 & 15657.06 & 167.0814 & 10959.94 & 4697.12 & 230000 & 230000 \\
\hline \multicolumn{12}{|l|}{ Flowrates in lb/h } \\
\hline Water & 1081.2 & 50827.1 & 0 & 0 & 249.8 & 147.0 & 102.8 & 102.9 & 44.1 & 0 & 0 \\
\hline Hydrogen & 8466.9 & 0 & 7620.2 & 190.2 & 457.8 & 457.8 & 0.0 & 320.5 & 137.3 & 0 & 0 \\
\hline Carbon & 0.0 & 0 & 0 & 0 & 0 & 0 & 0 & 0 & 0 & 0 & 0 \\
\hline Carbon Monoxide & 2899.8 & 0 & 0 & 0 & 0 & 0 & 0 & 0 & 0 & 0 & 0 \\
\hline Carbon Dioxide & 43945.3 & 0 & 0 & 0 & 6947.7 & 6947.3 & 0.4 & 4863.1 & 2084.2 & 0 & 0 \\
\hline Methane & 2878.1 & 0 & 0 & 0 & 2656.0 & 2656.0 & 0.0 & 1859.2 & 796.8 & 0 & 0 \\
\hline Ethylene & 0 & 0 & 0 & 0 & 0 & 0 & 0 & 0 & 0 & 0 & 0 \\
\hline Ethane & 0.1 & 0 & 0 & 0 & 1593.6 & 1593.4 & 0.1 & 1115.4 & 478.0 & 0 & 0 \\
\hline Propylene & 0 & 0 & 0 & 0 & 0 & 0 & 0 & 0 & 0 & 0 & 0 \\
\hline Propane & 0 & 0 & 0 & 0 & 1340.3 & 1339.8 & 0.4 & 937.9 & 401.9 & 0 & 0 \\
\hline I-Butane & 0 & 0 & 0 & 0 & 1189.4 & 1188.5 & 1.0 & 831.9 & 356.5 & 0 & 0 \\
\hline Formaldehyde & 0.2 & 0 & 0 & 0 & 0 & 0 & 0 & 0 & 0 & 0 & 0 \\
\hline 2-5-Xylenol & 0.0 & 0 & 0 & 0 & 1.8 & 0.4 & 1.4 & 0.3 & 0.1 & 0 & 0 \\
\hline $\mathrm{N}$-Heptane & 0 & 0 & 0 & 0 & 1332.6 & 1285.0 & 47.6 & 899.5 & 385.5 & 0 & 0 \\
\hline 1-ts-35-3C1CycC6 & 0 & 0 & 0 & 0 & 27.8 & 23.1 & 4.7 & 16.1 & 6.9 & 0 & 0 \\
\hline 3-3-5-TriMth-C7 & 0 & 0 & 0 & 0 & 5.8 & 4.3 & 1.5 & 3.0 & 1.3 & 0 & 0 \\
\hline N-PropylCyc-C6 & 0 & 0 & 0 & 0 & 10.9 & 8.7 & 2.3 & 6.1 & 2.6 & 0 & 0 \\
\hline 1-2-3-Mesitylene & 0 & 0 & 0 & 0 & 0.3 & 0.2 & 0.1 & 0.1 & 0 & 0 & 0 \\
\hline N-ButylCycHexane & 0 & 0 & 0 & 0 & 0.2 & 0.1 & 0.1 & 0.1 & 0 & 0 & 0 \\
\hline 1-2-DiC1-3C2-Bz & 0 & 0 & 0 & 0 & 0.3 & 0.1 & 0.2 & 0.1 & 0 & 0 & 0 \\
\hline Cis-Decalin & 0 & 0 & 0 & 0 & 1.5 & 0.7 & 0.8 & 0.5 & 0.2 & 0 & 0 \\
\hline Dimethyl-C11 & 0 & 0 & 0 & 0 & 1.5 & 0.2 & 1.3 & 0.1 & 0.1 & 0 & 0 \\
\hline 1-2-4-triethylbe & 0 & 0 & 0 & 0 & 0.3 & 0 & 0.2 & 0 & 0 & 0 & 0 \\
\hline 1-1-Bicyclohexyl & 0 & 0 & 0 & 0 & 0.0 & 0 & 0 & 0 & 0 & 0 & 0 \\
\hline Diphenyl & 0 & 0 & 0 & 0 & 0.1 & 0 & 0.1 & 0 & 0 & 0 & 0 \\
\hline diamantane & 0 & 0 & 0 & 0 & 1.7 & 0.3 & 1.4 & 0.2 & 0.1 & 0 & 0 \\
\hline Phenanthrene & 0 & 0 & 0 & 0 & 0 & 0 & 0 & 0 & 0 & 0 & 0 \\
\hline N-C15-CycloC5 & 0 & 0 & 0 & 0 & 0 & 0 & 0 & 0 & 0 & 0 & 0 \\
\hline Cyclopentane & 0 & 0 & 0 & 0 & 0 & 0 & 0 & 0 & 0 & 0 & 0 \\
\hline N-Pentadecane & 0 & 0 & 0 & 0 & 0 & 0 & 0 & 0 & 0 & 0 & 0 \\
\hline $\mathrm{N}$-Octadecane & 0 & 0 & 0 & 0 & 0 & 0 & 0 & 0 & 0 & 0 & 0 \\
\hline Tetralin & 0 & 0 & 0 & 0 & 0 & 0 & 0 & 0 & 0 & 0 & 0 \\
\hline Ethylbenzene & 0 & 0 & 0 & 0 & 0 & 0 & 0 & 0 & 0 & 0 & 0 \\
\hline Benzene & 0 & 0 & 0 & 0 & 0 & 0 & 0 & 0 & 0 & 0 & 0 \\
\hline N-Butane & 0 & 0 & 0 & 5.3 & 0.2 & 0.2 & 0.0 & 0.2 & 0.1 & 0 & 0 \\
\hline Toluene & 0 & 0 & 0 & 0 & 0 & 0 & 0 & 0 & 0 & 0 & 0 \\
\hline 1-3-5-Mesitylene & 0 & 0 & 0 & 0 & 0 & 0 & 0 & 0 & 0 & 0 & 0 \\
\hline P-Xylene & 0 & 0 & 0 & 0 & 4.2 & 3.6 & 0.6 & 2.5 & 1.1 & 0 & 0 \\
\hline $\mathrm{C} 9 \mathrm{H} 18$ & 0 & 0 & 0 & 2.5 & 0.1 & 0.1 & 0 & 0.1 & 0 & 0 & 0 \\
\hline MthCyclohexane & 0 & 0 & 0 & 7.0 & 0.3 & 0.3 & 0 & 0.2 & 0.1 & 0 & 0 \\
\hline
\end{tabular}


Table A.4. (contd)

\begin{tabular}{|c|c|c|c|c|c|c|c|c|c|c|c|}
\hline Stream No. & 615 & 630 & 706 & 707 & 721 & 725 & 730 & 733 & 734 & 735 & 736 \\
\hline Temp F & 150 & 311.6723 & 276.468 & 276.468 & 497.3775 & 497.3795 & 497.3795 & 700.0002 & 700 & 700 & 700 \\
\hline Pres psig & 329.5 & 1.5 & 670 & 670 & 650 & 650 & 650 & 645 & 645 & 645 & 645 \\
\hline Enth MMBtu/h & -185.86 & -447.3 & -1133.3 & -0.00703 & -1371.1 & -1316.6 & -675.88 & -121.47 & -486.09 & -28.903 & -22.468 \\
\hline Vapor mass fraction & 0.98557 & 1 & 0 & 0 & 0 & 0.355 & 1 & 1 & 1 & 1 & 1 \\
\hline Total lb/h & 51651.48 & 292778.2 & 171067 & 1.0604 & 214800.3 & 214800 & 119221.6 & 21991.57 & 88000 & 5193 & 4037 \\
\hline \multicolumn{12}{|l|}{ Flowrates in $\mathrm{lb} / \mathrm{h}$} \\
\hline Water & 1081.2 & 28603.1 & 171067.0 & 1.1 & 214800.3 & 214800.0 & 119221.6 & 21991.6 & 88000 & 5193.0 & 4037.0 \\
\hline Hydrogen & 846.7 & 0 & 0 & 0 & 0 & 0 & 0 & 0 & 0 & 0 & 0 \\
\hline Carbon & 0 & 0 & 0 & 0 & 0 & 0 & 0 & 0 & 0 & 0 & 0 \\
\hline Carbon Monoxide & 2899.8 & 0 & 0 & 0 & 0 & 0 & 0 & 0 & 0 & 0 & 0 \\
\hline Carbon Dioxide & 43945.3 & 78010.5 & 0 & 0 & 0 & 0 & 0 & 0 & 0 & 0 & 0 \\
\hline Methane & 2878.1 & 0 & 0 & 0 & 0 & 0 & 0 & 0 & 0 & 0 & 0 \\
\hline Ethylene & 0 & 0 & 0 & 0 & 0 & 0 & 0 & 0 & 0 & 0 & 0 \\
\hline Ethane & 0.1 & 0 & 0 & 0 & 0 & 0 & 0 & 0 & 0 & 0 & 0 \\
\hline Propylene & 0 & 0 & 0 & 0 & 0 & 0 & 0 & 0 & 0 & 0 & 0 \\
\hline Propane & 0 & 0 & 0 & 0 & 0 & 0 & 0 & 0 & 0 & 0 & 0 \\
\hline I-Butane & 0 & 0 & 0 & 0 & 0 & 0 & 0 & 0 & 0 & 0 & 0 \\
\hline Formaldehyde & 0 & 0 & 0 & 0 & 0 & 0 & 0 & 0 & 0 & 0 & 0 \\
\hline 2-5-Xylenol & 0 & 0 & 0 & 0 & 0 & 0 & 0 & 0 & 0 & 0 & 0 \\
\hline $\mathrm{N}$-Heptane & 0 & 0 & 0 & 0 & 0 & 0 & 0 & 0 & 0 & 0 & 0 \\
\hline 1-ts-35-3C1CycC6 & 0 & 0 & 0 & 0 & 0 & 0 & 0 & 0 & 0 & 0 & 0 \\
\hline 3-3-5-TriMth-C7 & 0 & 0 & 0 & 0 & 0 & 0 & 0 & 0 & 0 & 0 & 0 \\
\hline N-PropyICyc-C6 & 0 & 0 & 0 & 0 & 0 & 0 & 0 & 0 & 0 & 0 & 0 \\
\hline 1-2-3-Mesitylene & 0 & 0 & 0 & 0 & 0 & 0 & 0 & 0 & 0 & 0 & 0 \\
\hline N-ButylCycHexane & 0 & 0 & 0 & 0 & 0 & 0 & 0 & 0 & 0 & 0 & 0 \\
\hline 1-2-DiC1-3C2-Bz & 0 & 0 & 0 & 0 & 0 & 0 & 0 & 0 & 0 & 0 & 0 \\
\hline Cis-Decalin & 0 & 0 & 0 & 0 & 0 & 0 & 0 & 0 & 0 & 0 & 0 \\
\hline Dimethyl-C11 & 0 & 0 & 0 & 0 & 0 & 0 & 0 & 0 & 0 & 0 & 0 \\
\hline 1-2-4-triethylbe & 0 & 0 & 0 & 0 & 0 & 0 & 0 & 0 & 0 & 0 & 0 \\
\hline 1-1-Bicyclohexyl & 0 & 0 & 0 & 0 & 0 & 0 & 0 & 0 & 0 & 0 & 0 \\
\hline Diphenyl & 0 & 0 & 0 & 0 & 0 & 0 & 0 & 0 & 0 & 0 & 0 \\
\hline diamantane & 0 & 0 & 0 & 0 & 0 & 0 & 0 & 0 & 0 & 0 & 0 \\
\hline Phenanthrene & 0 & 0 & 0 & 0 & 0 & 0 & 0 & 0 & 0 & 0 & 0 \\
\hline N-C15-CycloC5 & 0 & 0 & 0 & 0 & 0 & 0 & 0 & 0 & 0 & 0 & 0 \\
\hline Cyclopentane & 0 & 0 & 0 & 0 & 0 & 0 & 0 & 0 & 0 & 0 & 0 \\
\hline N-Pentadecane & 0 & 0 & 0 & 0 & 0 & 0 & 0 & 0 & 0 & 0 & 0 \\
\hline N-Octadecane & 0 & 0 & 0 & 0 & 0 & 0 & 0 & 0 & 0 & 0 & 0 \\
\hline Tetralin & 0 & 0 & 0 & 0 & 0 & 0 & 0 & 0 & 0 & 0 & 0 \\
\hline Ethylbenzene & 0 & 0 & 0 & 0 & 0 & 0 & 0 & 0 & 0 & 0 & 0 \\
\hline Benzene & 0 & 0 & 0 & 0 & 0 & 0 & 0 & 0 & 0 & 0 & 0 \\
\hline N-Butane & 0 & 0 & 0 & 0 & 0 & 0 & 0 & 0 & 0 & 0 & 0 \\
\hline Toluene & 0 & 0 & 0 & 0 & 0 & 0 & 0 & 0 & 0 & 0 & 0 \\
\hline 1-3-5-Mesitylene & 0 & 0 & 0 & 0 & 0 & 0 & 0 & 0 & 0 & 0 & 0 \\
\hline P-Xylene & 0 & 0 & 0 & 0 & 0 & 0 & 0 & 0 & 0 & 0 & 0 \\
\hline $\mathrm{C} 9 \mathrm{H} 18$ & 0 & 0 & 0 & 0 & 0 & 0 & 0 & 0 & 0 & 0 & 0 \\
\hline MthCyclohexane & 0 & 0 & 0 & 0 & 0 & 0 & 0 & 0 & 0 & 0 & 0 \\
\hline
\end{tabular}


Table A.4. (contd)

\begin{tabular}{|c|c|c|}
\hline Stream No. & 743 & 754 \\
\hline Temp F & 499.8419 & 400 \\
\hline Pres psig & 665 & 665 \\
\hline Enth MMBtu/h & -501.74 & -536.23 \\
\hline Vapor mass fraction & 1 & 0 \\
\hline Total lb/h & 88500 & 82567.1 \\
\hline \multicolumn{3}{|l|}{ Flowrates in lb/h } \\
\hline Water & 88500.0 & 82567.1 \\
\hline Hydrogen & 0 & 0 \\
\hline Carbon & 0 & 0 \\
\hline Carbon Monoxide & 0 & 0 \\
\hline Carbon Dioxide & 0 & 0 \\
\hline Methane & 0 & 0 \\
\hline Ethylene & 0 & 0 \\
\hline Ethane & 0 & 0 \\
\hline Propylene & 0 & 0 \\
\hline Propane & 0 & 0 \\
\hline I-Butane & 0 & 0 \\
\hline Formaldehyde & 0 & 0 \\
\hline 2-5-Xylenol & 0 & 0 \\
\hline $\mathrm{N}$-Heptane & 0 & 0 \\
\hline 1-ts-35-3C1CycC6 & 0 & 0 \\
\hline 3-3-5-TriMth-C7 & 0 & 0 \\
\hline N-PropylCyc-C6 & 0 & 0 \\
\hline 1-2-3-Mesitylene & 0 & 0 \\
\hline N-ButylCycHexane & 0 & 0 \\
\hline 1-2-DiC1-3C2-Bz & 0 & 0 \\
\hline Cis-Decalin & 0 & 0 \\
\hline Dimethyl-C11 & 0 & 0 \\
\hline 1-2-4-triethylbe & 0 & 0 \\
\hline 1-1-Bicyclohexyl & 0 & 0 \\
\hline Diphenyl & 0 & 0 \\
\hline diamantane & 0 & 0 \\
\hline Phenanthrene & 0 & 0 \\
\hline N-C15-CycloC5 & 0 & 0 \\
\hline Cyclopentane & 0 & 0 \\
\hline N-Pentadecane & 0 & 0 \\
\hline $\mathrm{N}$-Octadecane & 0 & 0 \\
\hline Tetralin & 0 & 0 \\
\hline Ethylbenzene & 0 & 0 \\
\hline Benzene & 0 & 0 \\
\hline N-Butane & 0 & 0 \\
\hline Toluene & 0 & 0 \\
\hline 1-3-5-Mesitylene & 0 & 0 \\
\hline P-Xylene & 0 & 0 \\
\hline $\mathrm{C} 9 \mathrm{H} 18$ & 0 & 0 \\
\hline MthCyclohexane & 0 & 0 \\
\hline
\end{tabular}




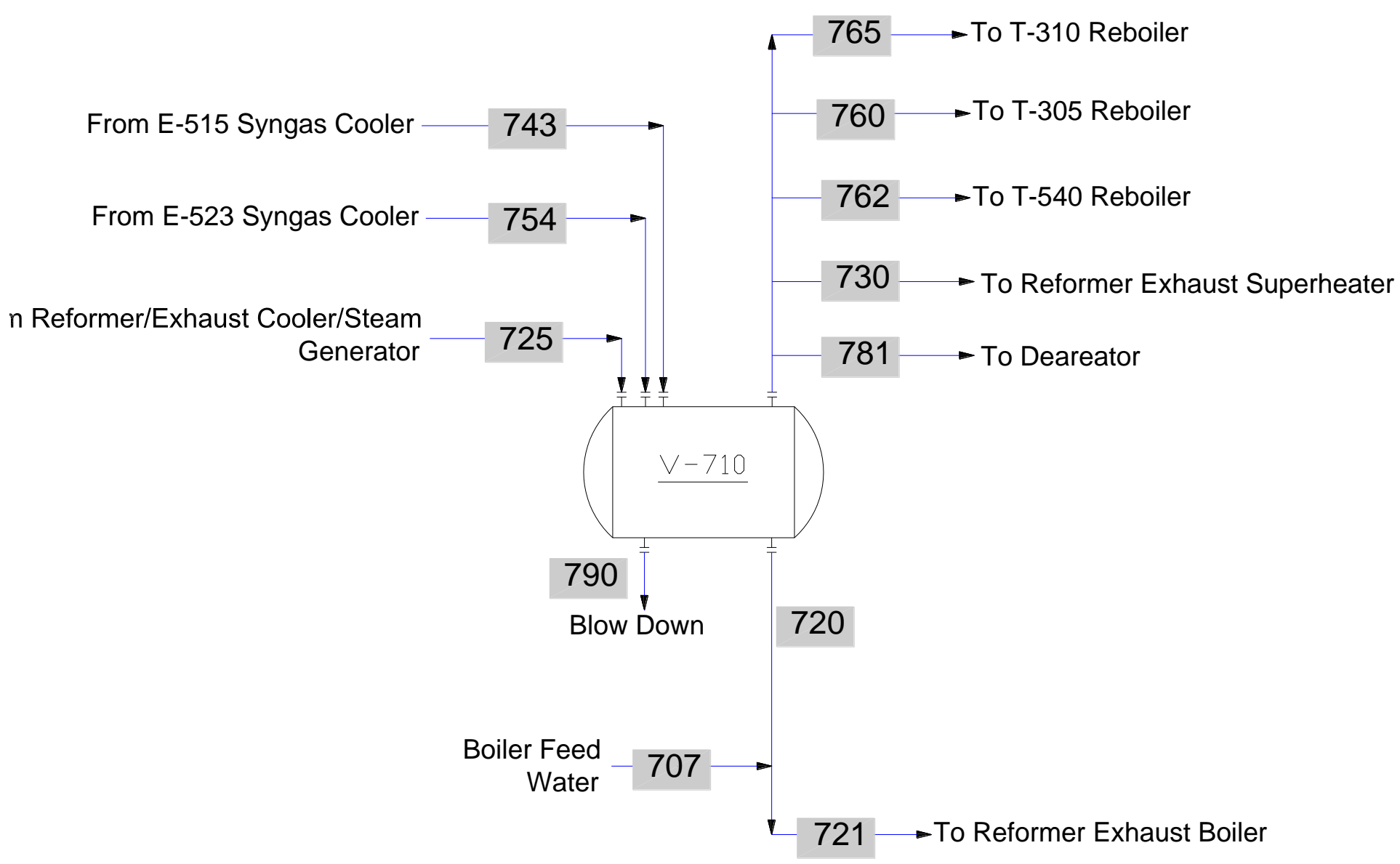

Figure A.5. Flow Diagram for the Steam Reformer Steam Drum 
Table A.5. Steam Reformer Steam Drum Heat and Material Balance

\begin{tabular}{|l|r|r|r|r|r|r|}
\hline Stream No. & 707 & 720 & 721 & 725 & 730 & 743 \\
\hline Temp F & 276.5 & 497.4 & 497.4 & 497.4 & 497.4 & 499.8 \\
\hline Pres psig & 670 & 650 & 650 & 650 & 650 & 665 \\
\hline Enth MMBtu/h & -0.007 & -1371.1 & -1371.1 & -1316.6 & -675.88 & -501.74 \\
\hline $\begin{array}{l}\text { Vapor mass } \\
\text { fraction }\end{array}$ & 0 & 0 & 0 & 0.355 & 1 & 1 \\
\hline Total lb/h & 1.1 & 214799.2 & 214800.3 & 214800.0 & 119221.6 & 88500.0 \\
\hline Flowrates in Ib/h & & & & & & 88500.0 \\
\hline Water & 1.1 & 214799.2 & 214800.3 & 214800.0 & 119221.6 & 8 \\
\hline
\end{tabular}

\begin{tabular}{|l|r|r|r|r|r|r|}
\hline Stream No. & 754 & 760 & 762 & 765 & 781 & 790 \\
\hline Temp F & 400.0 & 497.4 & 497.4 & 497.4 & 497.4 & 497.4 \\
\hline Pres psig & 665 & 650 & 650 & 650 & 650 & 650 \\
\hline Enth MMBtu/h & -536.23 & -91.839 & -21.543 & -23.81 & -47.62 & -122.87 \\
\hline $\begin{array}{l}\text { Vapor mass } \\
\text { fraction }\end{array}$ & 0 & 1 & 1 & 1 & 1 & 0 \\
\hline Total Ib/h & 82567.1 & 16200.0 & 3800.0 & 4200.0 & 8400.0 & 19250.0 \\
\hline Flowrates in Ib/h & & & & & & \\
\hline Water & 82567.1 & 16200.0 & 3800.0 & 4200.0 & 8400.0 & 19250.0 \\
\hline
\end{tabular}




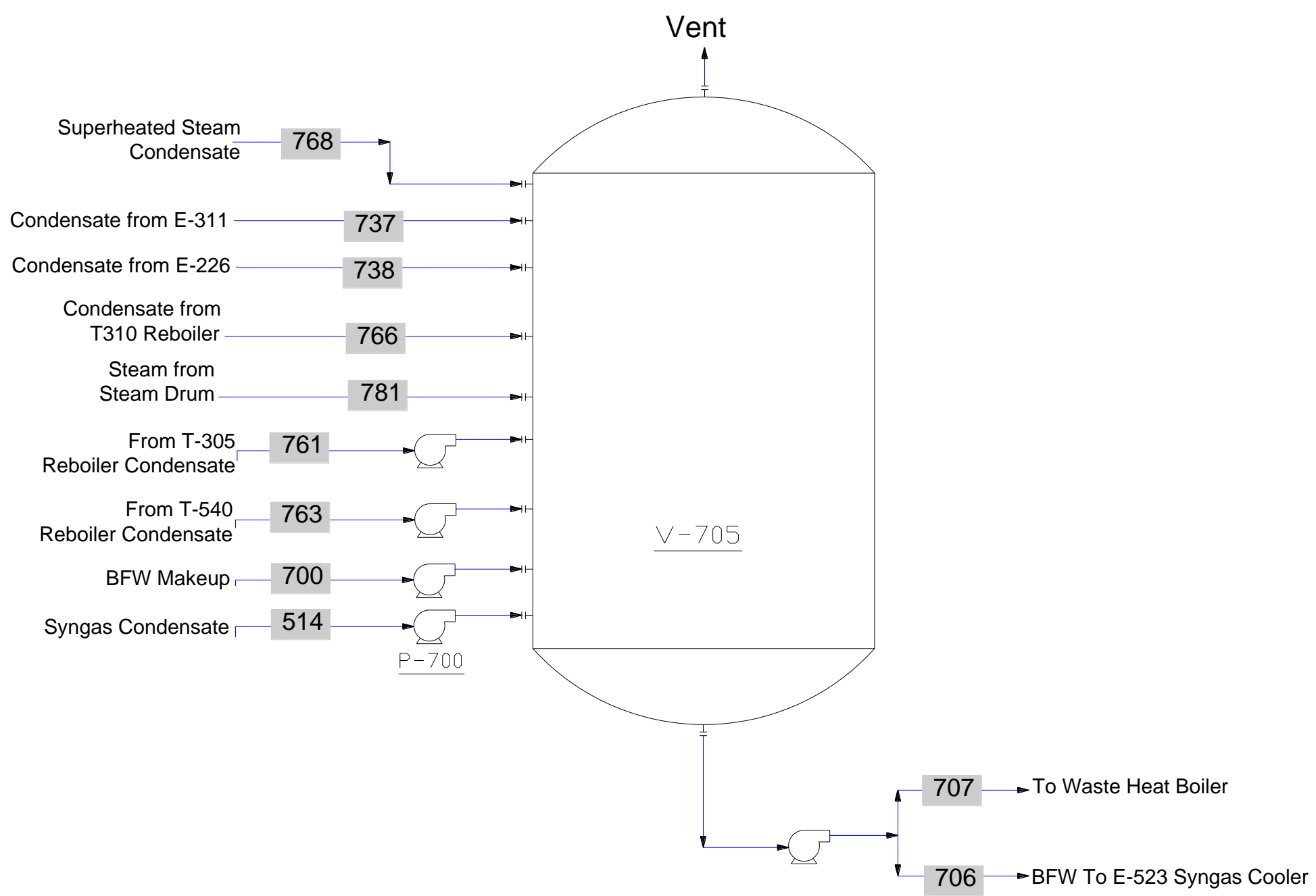

Figure A.6. Flow Diagram for Condensate Collection 
Table A.6. Condensate Collection Heat and Material Balance

\begin{tabular}{|l|r|r|r|r|r|r|}
\hline Stream No. & 514 & 700 & 706 & 707 & 737 & 738 \\
\hline Temp F & 150.0 & 60.0 & 276.5 & 276.5 & 496.6 & 496.6 \\
\hline Pres psig & 329.5 & 20 & 670 & 670 & 645 & 645 \\
\hline Enth MMBtu/h & -343.22 & -386.06 & -1133.3 & -0.0070253 & -33.135 & -25.758 \\
\hline $\begin{array}{l}\text { Vapor mass } \\
\text { fraction }\end{array}$ & 0 & 0 & 0 & 0 & $1.00 \mathrm{E}-06$ & $1.00 \mathrm{E}-06$ \\
\hline Total Ib/h & 50827.1 & 56419.0 & 171067.0 & 1.1 & 5193.4 & 4037.1 \\
\hline Flowrates in Ib/h & & & & & & \\
\hline Water & 50827.1 & 56419.0 & 171067.0 & 1.1 & 5193.4 & 4037.1 \\
\hline
\end{tabular}

\begin{tabular}{|l|r|r|r|r|r|r|}
\hline Stream No. & 761 & 763 & 766 & 768 & 781 & \\
\hline Temp F & 495.6 & 497.4 & 496.6 & 366.0 & 497.4 & \\
\hline Pres psig & 645 & 650 & 645 & 150 & 650 & \\
\hline Enth MMBtu/h & -103.44 & -24.193 & -26.71 & -143.64 & -47.62 & \\
\hline $\begin{array}{l}\text { Vapor mass } \\
\text { fraction }\end{array}$ & 0 & 0.023151 & 0.034147 & 0 & 1 & \\
\hline Total Ib/h & 16200.0 & 3800.0 & 4200.0 & 21992.0 & 8400.0 & \\
\hline Flowrates in Ib/h & & & & & & \\
\hline Water & 16200.0 & 3800.0 & 4200.0 & 21992.0 & 8400.0 & \\
\hline
\end{tabular}





\section{Appendix B}

\section{Equipment Cost Details}





\section{Appendix B}

\section{Equipment Cost Details}

Table B.1 lists the equipment cost details. Table B.2 lists the specifications for the standard equipment. 
Table B.1. Equipment Capital Cost Detail

\begin{tabular}{|c|c|c|c|c|c|c|c|c|c|c|c|c|c|}
\hline $\begin{array}{c}\# \\
\text { Reqd }\end{array}$ & Equipment Name & $\begin{array}{l}\text { Original } \\
\text { Stream } \\
\text { Metric } \\
\end{array}$ & $\begin{array}{l}\text { New } \\
\text { Stream } \\
\text { Metric }\end{array}$ & $\begin{array}{l}\text { Scaling } \\
\text { Units }\end{array}$ & $\begin{array}{l}\text { Size } \\
\text { Ratio } \\
\end{array}$ & $\begin{array}{l}\text { Original } \\
\text { Equip Cost } \\
\text { (per unit) }\end{array}$ & Base Year & $\begin{array}{l}\text { Scaling } \\
\text { Exp }\end{array}$ & $\begin{array}{l}\text { Install } \\
\text { Factor } \\
\end{array}$ & $\begin{array}{l}\text { Scaled and } \\
\text { Installed Cost } \\
\text { in Base Year }\end{array}$ & $\begin{array}{c}\text { Installed Cost } \\
\text { in } 2007 \$\end{array}$ & $\begin{array}{c}\text { Bare Equip } \\
\text { cost in } 2007 \$\end{array}$ & $\begin{array}{l}\text { Equip } \\
\text { Cost } \\
\text { Source } \\
\end{array}$ \\
\hline \multicolumn{14}{|c|}{ A100 Pyrolysis Oil } \\
\hline 1 & Feedstock Handling & 500 & 2,000 & tpd & 4.00 & $\$ 5,570,000$ & 2003 & 0.7 & 2.47 & $14,699,318$ & $19,212,106$ & $\$ 7,778,181$ & 1 \\
\hline 1 & CFB Pyrolyzer & 500 & 2,000 & tpd & 4.00 & $\$ 3,392,000$ & 2003 & 0.7 & 2.47 & $8,951,542$ & $11,699,724$ & $\$ 4,736,731$ & 1 \\
\hline 1 & Quench & 500 & 2,000 & tpd & 4.00 & $\$ 1,940,000$ & 2003 & 0.7 & 2.47 & $5,119,691$ & $6,691,470$ & $\$ 2,709,097$ & 1 \\
\hline 1 & Heat recovery & 500 & 0 & tpd & 0.00 & $\$ 1,140,000$ & 2003 & 0.7 & 2.47 & 0 & 0 & $\$ 0$ & 1 \\
\hline 1 & Product recovery and storage & 500 & 2,000 & tpd & 4.00 & $\$ 800,000$ & 2003 & 0.7 & 2.47 & $2,111,213$ & $2,759,369$ & $\$ 1,117,153$ & 1 \\
\hline 1 & Recycle & 500 & 2,000 & tpd & 4.00 & $\$ 1,380,000$ & 2003 & 0.7 & 2.47 & $3,641,842$ & $4,759,911$ & $\$ 1,927,090$ & 1 \\
\hline 1 & Steam and Power production & 500 & 0 & tpd & 0.00 & $\$ 3,160,000$ & 2003 & 0.7 & 2.47 & 0 & 0 & $\$ 0$ & 1 \\
\hline \multirow[t]{4}{*}{1} & Utilities & 500 & 0 & tpd & 0.00 & $\$ 3,130,000$ & 2003 & 0.7 & 2.47 & 0 & 0 & $\$ 0$ & 1 \\
\hline & & & & & & & & & & $\$ 34,523,605$ & $45,122,581$ & $\$ 18,268,251$ & \\
\hline & Equipment Contingency & & & & & & $35 \%$ & & & & $\$ 15,792,903$ & $\$ 6,393,888$ & \\
\hline & & & & & & & & & & & $60,915,484$ & $\$ 24,662,139$ & \\
\hline
\end{tabular}

\begin{tabular}{|c|c|c|c|c|c|c|c|c|c|c|c|c|c|}
\hline \multicolumn{14}{|c|}{ A 200 Pyrolysis Oil Upgrading } \\
\hline 2 & Feed Booster Pump & 1,000 & 2,000 & tpd & 2.00 & $\$ 30,000$ & 2004 & 0.65 & 2.47 & 232,551 & 275,070 & $\$ 111,364$ & 2 \\
\hline 2 & Feed Pump & 1,000 & 2,000 & tpd & 2.00 & $\$ 122,000$ & 2004 & 0.65 & 2.47 & 945,706 & $1,118,617$ & $\$ 452,882$ & 2 \\
\hline 1 & $1^{\text {st }}$ stage Reactor & 2,038 & 1,959 & liq scfh & 0.96 & $\$ 860,700$ & 1Q 2007 & 0.65 & 2.47 & $2,125,929$ & $2,120,904$ & $\$ 858,666$ & 3 \\
\hline 1 & $2^{\text {nd }}$ stage Reactor & 2,038 & 1,959 & liq scfh & 0.96 & $\$ 9,018,000$ & 1Q 2007 & 0.65 & 2.47 & $19,852,131$ & $22,221,810$ & $\$ 8,996,684$ & 3 \\
\hline 1 & $\begin{array}{l}2^{\text {nd }} \text { stage Three Phase } \\
\text { Separator }\end{array}$ & 174,497 & 161,375 & $\mathrm{lb} / \mathrm{h}$ & 0.92 & $\$ 673,300$ & 1Q 2005 & 0.65 & 2.47 & $1,663,113$ & $1,777,236$ & $\$ 719,529$ & 3 \\
\hline 1 & $\begin{array}{l}1^{\text {st }} \text { Feed/Product Heat } \\
\text { Exchanger }\end{array}$ & 59.85 & 38.38 & mmbtuh & 0.64 & $\$ 647,800$ & $1 Q 2005$ & 0.65 & 2.47 & $1,628,026$ & $1,347,791$ & $\$ 545,664$ & 3 \\
\hline 1 & $\begin{array}{l}2^{\text {nd }} \text { Feed/Product Heat } \\
\text { Exchanger }\end{array}$ & 33.30 & 1.22 & mmbtuh & 0.04 & $\$ 622,200$ & 1Q 2005 & 0.65 & 2.47 & $1,537,134$ & 201,410 & $\$ 81,542$ & 3 \\
\hline 1 & Fired Heater & 8.35 & 40.00 & mmbtuh & 8.18 & $\$ 378,000$ & 2004 & 0.65 & 2.47 & 933,660 & $3,057,432$ & $\$ 1,237,827$ & 2 \\
\hline 1 & Air Cooler & 40.38 & 28.10 & mmbtuh & 0.70 & $\$ 228,000$ & $1 Q 2005$ & 0.65 & 2.47 & 548,093 & 500,254 & $\$ 202,532$ & 3 \\
\hline 1 & Product Trim Cooler & 8.35 & 8.35 & mmbtuh & 1.00 & $\$ 128,700$ & $1 Q 2005$ & 0.65 & 2.47 & 317,889 & 357,424 & $\$ 144,706$ & 3 \\
\hline 1 & PSA & 10 & 15 & $\begin{array}{r}\text { mmscfd } \\
\mathrm{H} 2 \\
\end{array}$ & 1.50 & $\$ 1,750,000$ & 2004 & 0.65 & 2.47 & $4,838,004$ & $2,694,155$ & $\$ 1,090,751$ & 2 \\
\hline 1 & Product Flash Drum & 71,462 & 69,520 & $\mathrm{lb} / \mathrm{h}$ & 0.97 & $\$ 38,800$ & 1Q 2005 & 0.65 & 2.47 & 95,836 & 105,842 & $\$ 42,851$ & 3 \\
\hline 1 & Product Pump & 1,000 & 2,000 & tpd & 2.00 & $\$ 39,000$ & 2004 & 0.65 & 2.47 & 151,158 & 357,591 & $\$ 144,774$ & 2 \\
\hline \multirow[t]{4}{*}{1} & Hydrogen Compressor & 2,840 & 2,840 & acfm & 1.00 & $\$ 3,869,400$ & 1Q 2005 & 0.65 & 2.47 & $9,557,418$ & $10,746,045$ & $\$ 4,350,625$ & 3 \\
\hline & & & & & & & \multicolumn{2}{|c|}{ Subtotal } & & $\$ 43,497,310$ & $\$ 46,881,581$ & $\$ 18,980,397$ & \\
\hline & Equipment Contingency & & & & & & $15 \%$ & & & & $\$ 7,032,237$ & $\$ 2,847,060$ & \\
\hline & & & & & & & & & & & $\$ 53,913,818$ & $\$ 21,827,457$ & \\
\hline
\end{tabular}


Table B.1. (contd)

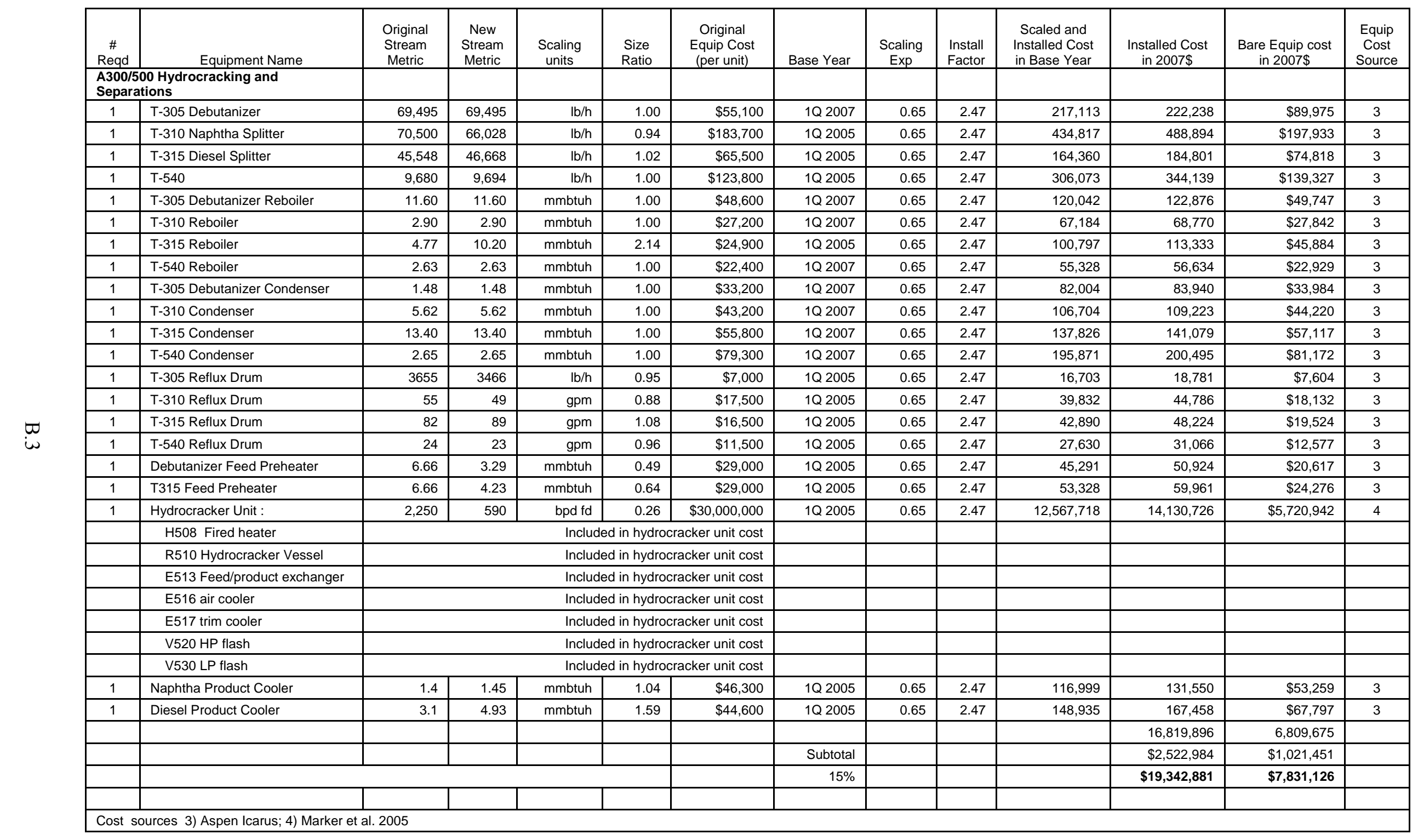


Table B.1. (contd)

\begin{tabular}{|c|c|c|c|c|c|c|c|c|c|c|c|c|c|c|}
\hline & $\begin{array}{c}\# \\
\text { Reqd }\end{array}$ & Equipment Name & $\begin{array}{l}\text { Original } \\
\text { Stream } \\
\text { Metric } \\
\end{array}$ & $\begin{array}{l}\text { New } \\
\text { Stream } \\
\text { Metric }\end{array}$ & $\begin{array}{l}\text { Scaling } \\
\text { units }\end{array}$ & $\begin{array}{l}\text { Size } \\
\text { Ratio }\end{array}$ & $\begin{array}{c}\text { Original } \\
\text { Equip Cost } \\
\text { (per unit) }\end{array}$ & $\begin{array}{l}\text { Base } \\
\text { Year }\end{array}$ & $\begin{array}{l}\text { Scaling } \\
\text { Exp }\end{array}$ & $\begin{array}{l}\text { Install } \\
\text { Factor } \\
\end{array}$ & $\begin{array}{l}\text { Scaled and } \\
\text { Installed Cost } \\
\text { in Base Year } \\
\end{array}$ & $\begin{array}{l}\text { Installed Cost } \\
\text { in } 2007 \$\end{array}$ & $\begin{array}{l}\text { Bare Equip cost } \\
\text { in } 2007 \$\end{array}$ & $\begin{array}{c}\text { Equip } \\
\text { Cost } \\
\text { Source } \\
\end{array}$ \\
\hline & \multicolumn{2}{|c|}{ A 700 Utilities and Auxiliaries } & & & & & & & & & & & & \\
\hline & 1 & Wastewater treatment incinerator & 1,000 & 0 & tpd & 0.00 & $\$ 442,000$ & 2004 & 1,000 & 2.47 & 0 & 0 & $\$ 0$ & 5 \\
\hline & 1 & WWT anaerobic/aerobic digestion & 1,000 & 2,000 & tpd & 2.00 & $\$ 1,554,000$ & 2004 & 1,000 & 2.47 & $2,438,487$ & $2,884,336$ & $\$ 1,167,747$ & 5 \\
\hline & 1 & Wastewater storage & 593,849 & 672,840 & gallons & 1.13 & 226,710 & 1Q 2005 & 593,849 & & 607,324 & 682,855 & $\$ 276,459$ & \\
\hline & 1 & Field-Erected CTW w/pumps, etc & 10,400 & 7,549 & $\mathrm{gpm}$ & 0.73 & $\$ 352,000$ & 1Q 2005 & 0.78 & 2.47 & 274,164 & 308,261 & $\$ 124,802$ & 3 \\
\hline & & & & & & & & & & & & & & \\
\hline \multirow{18}{*}{$\underset{\Delta}{\oplus}$} & 1 & Plant Air Compressor & 2,000 & 2,000 & tpd & 1.00 & $\$ 32,376$ & 2002 & 0.34 & 2.47 & 79,969 & 106,212 & $\$ 43,001$ & 6 \\
\hline & 1 & Hydraulic Truck Dump with Scale & 2,000 & 2,000 & tpd & 1.00 & $\$ 80,000$ & 1998 & 0.6 & 2.47 & 197,600 & 266,553 & $\$ 107,916$ & 6 \\
\hline & 1 & Firewater Pump & 2,000 & 2,000 & tpd & 1.00 & $\$ 18,400$ & 1997 & 0.79 & 2.47 & 45,448 & 61,783 & $\$ 25,013$ & 6 \\
\hline & 1 & Diesel Pump & 2,000 & 2,000 & tpd & 1.00 & $\$ 6,100$ & 1997 & 0.79 & 2.47 & 15,067 & 20,482 & $\$ 8,292$ & 6 \\
\hline & 1 & Instrument Air Dryer & 2,000 & 2,000 & tpd & 1.00 & $\$ 8,349$ & 2002 & 0.6 & 2.47 & 20,622 & 27,389 & $\$ 11,089$ & 6 \\
\hline & 1 & Plant Air Receiver & 2,000 & 2,000 & tpd & 1.00 & $\$ 7,003$ & 2002 & 0.72 & 2.47 & 17,297 & 22,974 & $\$ 9,301$ & 6 \\
\hline & 1 & Firewater Storage Tank & 2,000 & 2,000 & tpd & 1.00 & $\$ 166,100$ & 1997 & 0.51 & 2.47 & 410,267 & 557,726 & $\$ 225,800$ & 6 \\
\hline & 1 & Ammonia Pump & \multicolumn{4}{|c|}{ included in Stream Reformer Cost } & & & & & & & & \\
\hline & 1 & Hydrazine Pump & \multicolumn{4}{|c|}{ included in Stream Reformer Cost } & & & & & & & & \\
\hline & 1 & Ammonia Storage Tank & \multicolumn{4}{|c|}{ included in Stream Reformer Cost } & & & & & & & & \\
\hline & 1 & Hydrazine Storage Tank & \multicolumn{4}{|c|}{ included in Stream Reformer Cost } & & & & & & & & \\
\hline & 1 & Flare & \multicolumn{4}{|c|}{ included in Stream Reformer Cost } & & & & & & & & \\
\hline & 1 & Feed Storage & $1,056,846$ & $1,056,846$ & gallons & 1.00 & 470,000 & 1Q 2005 & 0.65 & 2.47 & $1,160,900$ & $1,305,278$ & $\$ 528,452$ & 3 \\
\hline & 1 & Product Storage & 558,000 & 681,114 & gallons & 1.22 & 320,384 & 1Q 2005 & 0.65 & 2.47 & 836,744 & 940,807 & $\$ 380,894$ & 3 \\
\hline & 1 & Product Storage & 558,000 & 712,728 & gallons & 1.28 & 320,384 & 1Q 2005 & 0.65 & 2.47 & 930,580 & $1,046,313$ & $\$ 423,609$ & 3 \\
\hline & & & & & & & & Subtotal & & & & $\$ 8,230,968$ & $\$ 3,332,376$ & \\
\hline & & Equipment Contingency & & & & & & $15 \%$ & & & & $\$ 1,234,645$ & $\$ 499,856$ & \\
\hline & & & & & & & & & & & & $\$ 9,465,613$ & $\$ 3,832,232$ & \\
\hline
\end{tabular}


Table B.1. (contd)

\begin{tabular}{|c|c|c|c|c|c|c|c|c|c|c|c|c|}
\hline $\begin{array}{c}\# \\
\text { Reqd }\end{array}$ & Equipment Name & $\begin{array}{l}\text { Original } \\
\text { Stream } \\
\text { Metric }\end{array}$ & $\begin{array}{l}\text { New } \\
\text { Stream } \\
\text { Metric }\end{array}$ & $\begin{array}{c}\text { Scaling } \\
\text { units }\end{array}$ & $\begin{array}{l}\text { Size } \\
\text { Ratio }\end{array}$ & $\begin{array}{l}\text { Original } \\
\text { Equip Cost } \\
\text { (per unit) }\end{array}$ & $\begin{array}{l}\text { Base } \\
\text { Year }\end{array}$ & $\begin{array}{c}\text { Scaling } \\
\text { Exp }\end{array}$ & $\begin{array}{l}\text { Install } \\
\text { Factor }\end{array}$ & $\begin{array}{l}\text { Scaled and } \\
\text { Installed Cost } \\
\text { in Base Year }\end{array}$ & $\begin{array}{c}\text { Total Project } \\
\text { Investment }\end{array}$ & $\begin{array}{l}\text { Equip } \\
\text { Cost } \\
\text { Source } \\
\end{array}$ \\
\hline \multicolumn{13}{|c|}{ A 600 Hydrogen Plant } \\
\hline \multirow[t]{5}{*}{1} & Steam Reformer System w/ & 24.5 & 34.4 & $\begin{array}{r}\text { mmscfd } \\
\mathrm{H} 2 \\
\end{array}$ & 1.40 & $\$ 69,900,000$ & $\begin{array}{r}\text { May } \\
2007 \\
\end{array}$ & 0.65 & 2.47 & $87,152,973$ & $86,106,854$ & 7 \\
\hline & associated OSBL & & & & & & & & & & & \\
\hline & & & & & & & Subtotal & & & $87,152,973$ & $86,106,854$ & \\
\hline & Equipment Contingency & & & & & & $0 \%$ & & & 0 & 0 & \\
\hline & & & & & & & & & & $87,152,973$ & $86,106,854$ & \\
\hline
\end{tabular}


Table B.2. Standard Equipment Specifications

\begin{tabular}{|c|c|c|c|c|c|c|c|}
\hline Tag & Description & $\mathbf{T},{ }^{\circ} \mathbf{F}$ & P, psig & \multicolumn{3}{|c|}{ Type and Size } & Metallurgy \\
\hline $\mathrm{R}-205$ & $1^{\text {st }}$ stage Reactor & 750 & 2530 & & $\begin{array}{r}\text { Diameter, } \mathrm{ft} \\
\text { Length, } \mathrm{ft}\end{array}$ & $\begin{array}{l}8 \\
41\end{array}$ & 316 SS clad \\
\hline $\mathrm{R}-215$ & $2^{\text {nd }}$ stage Reactor & 780 & 2530 & & $\begin{array}{r}\text { Diameter, } \mathrm{ft} \\
\text { Length, } \mathrm{ft}\end{array}$ & $\begin{array}{l}16 \\
80\end{array}$ & $316 \mathrm{SS}$ clad \\
\hline $\mathrm{V}-222$ & Three-Phase Separator & 100 & 700 & & $\begin{array}{r}\text { Diameter, } \mathrm{ft} \\
\text { Length, } \mathrm{ft}\end{array}$ & $\begin{array}{l}10 \\
58\end{array}$ & $316 \mathrm{SS}$ \\
\hline E-202 & $\begin{array}{l}1^{\text {st }} \text { Feed/Product Heat } \\
\text { Exchanger }\end{array}$ & 750 & 2530 & $\begin{array}{l}\text { Shell \& tube } \\
\text { floating head }\end{array}$ & $\begin{array}{r}\text { Area, } \mathrm{ft}^{2} \\
\text { Duty, MMBtu/h} \\
\end{array}$ & $\begin{array}{l}6712 \\
59.9 \\
\end{array}$ & $316 \mathrm{SS}$ \\
\hline E-206 & $\begin{array}{l}2^{\text {nd }} \text { Feed/Product Heat } \\
\text { Exchanger }\end{array}$ & 750 & 2530 & $\begin{array}{l}\text { Shell \& tube } \\
\text { floating head }\end{array}$ & $\begin{array}{r}\text { Area, ft2 } \\
\text { Duty, MMBtu/h }\end{array}$ & $\begin{array}{l}6518 \\
33.3\end{array}$ & $316 \mathrm{SS}$ \\
\hline H-210 & Fired Heater & 850 & 2530 & & Duty, MMBtu/h & 8.18 & $316 \mathrm{SS}$ \\
\hline E-220 & Air Cooler & 400 & 750 & Air Fin & $\begin{array}{r}\text { Area, ft2 } \\
\text { Duty, MMBtu/h }\end{array}$ & $\begin{array}{l}6170 \\
40.4 \\
\end{array}$ & $316 \mathrm{SS}$ \\
\hline E-221 & Product Trim Cooler & 150 & 700 & $\begin{array}{l}\text { Shell \& tube } \\
\text { floating head }\end{array}$ & $\begin{array}{r}\text { Area, ft2 } \\
\text { Duty, MMBtu/h }\end{array}$ & $\begin{array}{l}3589 \\
8.35\end{array}$ & $316 \mathrm{SS}$ \\
\hline $\mathrm{V}-225$ & Product Flash Drum & 100 & 100 & & $\begin{array}{r}\text { Diameter, } \mathrm{ft} \\
\text { Length, } \mathrm{ft}\end{array}$ & $\begin{array}{l}7 \\
21 \\
\end{array}$ & $316 \mathrm{SS}$ \\
\hline $\mathrm{C}-250$ & Hydrogen Compressor & 300 inlet & & $\begin{array}{r}\text { Reciprocating } \\
\text { motor drive }\end{array}$ & 3 stage & $2480 \mathrm{acfm}$ & \\
\hline $\mathrm{T}-305$ & Debutanizer & 50 & 440 & & $\begin{array}{r}\text { Diameter, } \mathrm{ft} \\
\text { \# trays }\end{array}$ & $\begin{array}{l}5 \\
18 \\
\end{array}$ & $\mathrm{CS}$ \\
\hline $\mathrm{T}-310$ & Naphtha Splitter & 50 & 500 & & $\begin{array}{r}\text { Diameter, } \mathrm{ft} \\
\text { \# trays }\end{array}$ & $\begin{array}{l}3 \\
28 \\
\end{array}$ & $\mathrm{CS}$ \\
\hline $\mathrm{T}-315$ & Diesel Splitter & 50 & 700 & & $\begin{array}{r}\text { Diameter, } \mathrm{ft} \\
\text { \# trays }\end{array}$ & $\begin{array}{l}5 \\
8\end{array}$ & $\mathrm{CS}$ \\
\hline $\mathrm{T}-540$ & $\mathrm{~T}-540$ & 50 & 400 & & $\begin{array}{r}\text { Diameter, } \mathrm{ft} \\
\text { \# trays }\end{array}$ & $\begin{array}{l}3 \\
28 \\
\end{array}$ & $\mathrm{CS}$ \\
\hline $\mathrm{T}-305$ & Debutanizer Reboiler & 150 & 750 & $\begin{array}{l}\text { Shell \& tube } \\
\text { floating head }\end{array}$ & $\begin{array}{r}\text { Area, } \mathrm{ft}^{2} \\
\text { Duty, MMBtu/h }\end{array}$ & $\begin{array}{l}975 \\
11.6\end{array}$ & Tubes 316/ CS Shell \\
\hline E-310R & Reboiler & 150 & 700 & $\begin{array}{l}\text { Shell \& tube } \\
\text { floating head }\end{array}$ & $\begin{array}{r}\text { Area, } \mathrm{ft}^{2} \\
\text { Duty, MMBtu/h }\end{array}$ & $\begin{array}{l}224 \\
2.9\end{array}$ & Tubes 316/ CS Shell \\
\hline E-315R & Reboiler & 150 & 500 & $\begin{array}{l}\text { Shell \& tube } \\
\text { floating head }\end{array}$ & $\begin{array}{r}\text { Area, } \mathrm{ft}^{2} \\
\text { Duty, MMBtu/h }\end{array}$ & $\begin{array}{l}218 \\
4.7\end{array}$ & Tubes 316/ CS Shell \\
\hline E-540R & Reboiler & 150 & 880 & $\begin{array}{l}\text { Shell \& tube } \\
\text { floating head }\end{array}$ & $\begin{array}{r}\text { Area, } \mathrm{ft}^{2} \\
\text { Duty, MMBtu/h }\end{array}$ & $\begin{array}{l}127 \\
2.63\end{array}$ & Tubes 316/ CS Shell \\
\hline
\end{tabular}


Table B.2. (contd)

\begin{tabular}{|c|c|c|c|c|c|c|c|}
\hline E-305C & Debutanizer Condenser & 150 & 200 & Air Fin & $\begin{array}{r}\text { Area, ft2 } \\
\text { Duty, MMBtu/h }\end{array}$ & $\begin{array}{l}209 \\
1.5\end{array}$ & CS Tubes \\
\hline E-310C & Naphtha Splitter Condenser & 150 & 200 & Air Fin & $\begin{array}{r}\text { Area, ft2 } \\
\text { Duty, MMBtu/h }\end{array}$ & $\begin{array}{l}503 \\
5.6\end{array}$ & CS Tubes \\
\hline E-315C & Diesel Splitter Condenser & 150 & 300 & Air Fin & $\begin{array}{r}\text { Area, ft2 } \\
\text { Duty, MMBtu/h }\end{array}$ & $\begin{array}{l}670 \\
13.4 \\
\end{array}$ & CS Tubes \\
\hline E-540C & T-540 Condenser & 150 & 400 & Air Fin & $\begin{array}{r}\text { Area, ft2 } \\
\text { Duty, MMBtu/h }\end{array}$ & $\begin{array}{l}1680 \\
2.7 \\
\end{array}$ & CS Tubes \\
\hline D-305 & Debutanizer Reflux Drum & 15 & 250 & $\begin{array}{r}\text { Horizontal, } 5 \\
\text { min holdup }\end{array}$ & $\begin{array}{r}\text { Diameter, } \mathrm{ft} \\
\text { Length, } \mathrm{ft}\end{array}$ & $\begin{array}{l}2 \\
6\end{array}$ & $\mathrm{CS}$ \\
\hline D-310 & Naphtha Splitter Reflux Drum & 15 & 350 & $\begin{array}{r}\text { Horizontal, } 5 \\
\text { min holdup }\end{array}$ & $\begin{array}{r}\text { Diameter, } \mathrm{ft} \\
\text { Length, } \mathrm{ft}\end{array}$ & $\begin{array}{l}4.8 \\
14.3\end{array}$ & $\mathrm{CS}$ \\
\hline D-315 & Diesel Splitter Reflux Drum & 15 & 425 & $\begin{array}{r}\text { Horizontal, } 5 \\
\text { min holdup }\end{array}$ & $\begin{array}{r}\text { Diameter, } \mathrm{ft} \\
\text { Length, } \mathrm{ft}\end{array}$ & $\begin{array}{l}4.5 \\
13.5\end{array}$ & $\mathrm{CS}$ \\
\hline D-540 & T-540 Reflux Drum & 15 & 250 & $\begin{array}{r}\text { Horizontal, } 5 \\
\text { min holdup } \\
\end{array}$ & $\begin{array}{r}\text { Diameter, } \mathrm{ft} \\
\text { Length, } \mathrm{ft}\end{array}$ & $\begin{array}{l}3.4 \\
10.3 \\
\end{array}$ & $\mathrm{CS}$ \\
\hline E-305 & Debutanizer Feed Preheater & 150 & 530 & Pre-engineered & $\begin{array}{r}\text { Area, } \mathrm{ft}^{2} \\
\text { Duty, MMBtu/h}\end{array}$ & $\begin{array}{l}83 \\
3.33 \\
\end{array}$ & $\mathrm{CS}$ \\
\hline E-311 & Diesel Splitter Feed Preheater & 150 & & $\begin{array}{l}\text { Shell \& tube } \\
\text { floating head }\end{array}$ & $\begin{array}{r}\text { Area, ft2 } \\
\text { Duty, MMBtu/h }\end{array}$ & $\begin{array}{l}574 \\
3.55 \\
\end{array}$ & $\mathrm{CS}$ \\
\hline E-542 & Naphtha Product Cooler & 50 & 475 & Air Fin & $\begin{array}{r}\text { Area, } \mathrm{ft}^{2} \\
\text { Duty, MMBtu/h}\end{array}$ & 838 & $\mathrm{CS}$ \\
\hline E-543 & Diesel Product Cooler & 50 & 475 & Air Fin & $\begin{array}{r}\text { Area, } \mathrm{ft}^{2} \\
\text { Duty, MMBtu/h}\end{array}$ & $\begin{array}{l}670 \\
3.1 \\
\end{array}$ & $\mathrm{CS}$ \\
\hline
\end{tabular}






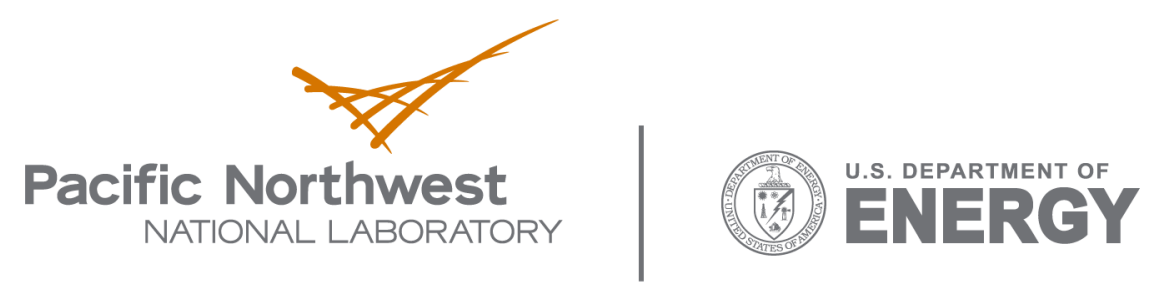

902 Battelle Boulevard

P.O. Box 999

Richland, WA 99352

1-888-375-PNNL (7665)

www.pnl.gov 